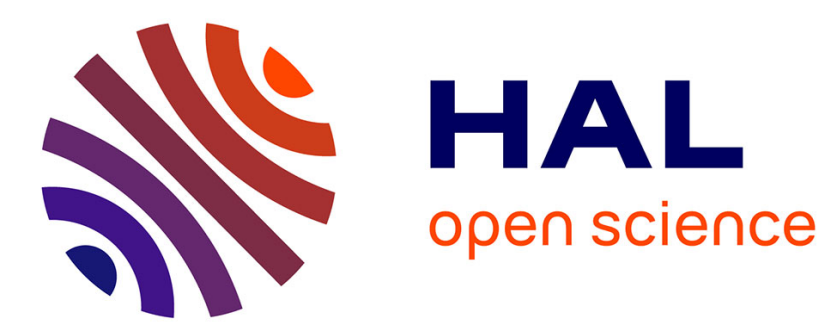

\title{
Rare Earth Polymerization Catalysts Supported by Bulky Aminopyridinato Ligands
}

Rhett Kempe

\section{To cite this version:}

Rhett Kempe. Rare Earth Polymerization Catalysts Supported by Bulky Aminopyridinato Ligands. Journal of Inorganic and General Chemistry / Zeitschrift für anorganische und allgemeine Chemie, 2010, 636 (12), pp.2135. 10.1002/zaac.201000195 . hal-00560680

\section{HAL Id: hal-00560680 \\ https://hal.science/hal-00560680}

Submitted on 29 Jan 2011

HAL is a multi-disciplinary open access archive for the deposit and dissemination of scientific research documents, whether they are published or not. The documents may come from teaching and research institutions in France or abroad, or from public or private research centers.
L'archive ouverte pluridisciplinaire HAL, est destinée au dépôt et à la diffusion de documents scientifiques de niveau recherche, publiés ou non, émanant des établissements d'enseignement et de recherche français ou étrangers, des laboratoires publics ou privés. 


\section{Rare Earth Polymerization Catalysts Supported by Bulky Aminopyridinato Ligands}

\begin{tabular}{|r|l|}
\hline Journal: & Zeitschrift für Anorganische und Allgemeine Chemie \\
\hline Manuscript ID: & zaac.201000195.R1 \\
\hline Wiley - Manuscript type: & Research Report \\
\hline Date Submitted by the \\
Author: & 01-Jun-2010 \\
\hline Complete List of Authors: & Kempe, Rhett; Universitaet Bayreuth, Inorganic Chemistry II \\
\hline Keywords: & rare earth, N ligand \\
\hline \multicolumn{2}{|l}{} \\
\hline
\end{tabular}

\section{\scholaroNE" \\ Manuscript Central}




\title{
Rare Earth Polymerization Catalysts Supported by Bulky Aminopyridinato Ligands
}

\author{
Rhett Kempe \\ Anorganische Chemie II \\ Universität Bayreuth \\ 95440 Bayreuth \\ Mail: kempe@uni-bayreuth.de

\section{Rhett Kempe}

Rhett Kempe was born in Dresden in 1964. He studied chemistry at the Universität Leipzig including research stays in Jena (Prof. D. Walther) und Stuttgart (Prof. H.-G. von Schnering) and received his PhD degree (organo nickel chemistry) under the supervision of Prof. J. Sieler (1989). During a DAAD postdoctoral research fellowship at MIT (1992/1993) with Prof. R. R. Schrock he became interested in N2 activation. After a period at the MPI für Kohlenforschung in Mülheim (1993/1994) he begun to study for his habilitation in the MaxPlanck-Gesellschaft Group "Complex Catalysis" led by Prof. U. Rosenthal. The habilitation (amido metal chemistry) followed at the Universität Rostock in 1998. He worked as a group leader in the Institut für Organische Katalyseforschung Rostock (IfOK) for two years and then moved as a visiting scientist in 2000/2001 to the University of Melbourne (Prof. R. Robson's group). He became a Professor of Inorganic Chemistry at the University of Oldenburg in 2001 and was appointed to a Chair of Inorganic Chemistry at the University of Bayreuth in 2002. In 2006 he obtained an offer from the University of Rostock to hold the Chair of Inorganic Chemistry at this university and to join the Leibniz-Institute of Catalysis Rostock (LIKAT) and decided to stay in Bayreuth. His research interest is the development of novel catalyst systems. He is an author of more than 300 publications and was awarded, for instance, the Karl-Winnacker-Stipendium and the Heisenberg-Stipendium. 


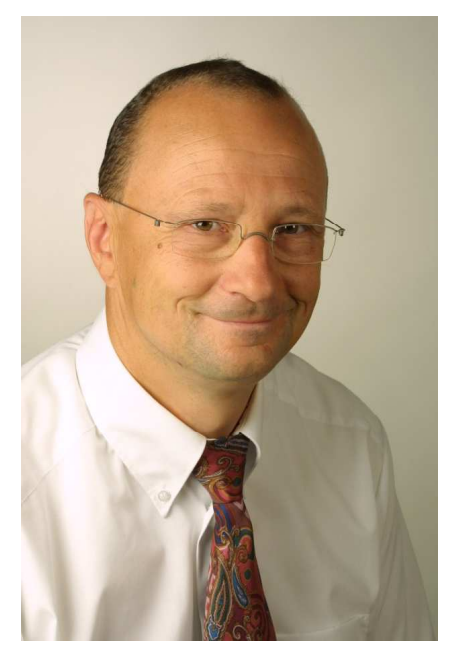

\section{Abstract}

The coordination and polymerization chemistry of molecular rare earth catalysts stabilized by bulky aminopyridinato (= Ap) ligands are reviewed. The selective synthesis of dialkyls allows the generation of rare earth alkyl hydride clusters and the generation of organo rare earth cations. These cations are able to catalyze polyethylene chain growing at aluminum and are able to polymerize isoprene stereoselectively. Complexes of the type $\left[\mathrm{ApLn}(\operatorname{thf})_{\mathrm{m}} \mathrm{X}_{2}\right](\mathrm{X}=\mathrm{Cl}$, $\mathrm{Br} ; \mathrm{m}=2,3)$ allow controlled ring opening polymerization of $\varepsilon$-caprolactone in the presence of $\mathrm{NaBH}_{4} . \alpha, \omega$-Dihydroxytelechelic polymers are obtained. Bis-Ap alkyl complexes undergo $\mathrm{C}-\mathrm{H}$ activation of one of the methyl groups of the Ap ligand. The rates of this activation reaction depend strongly from the nature of the "leaving" ligand and the radius of the rare earth ion that mediates $\mathrm{C}-\mathrm{H}$ activation.

\section{Introduction}

Aminopyridatinato (= Ap) ligands, ${ }^{1}$ deprotonated 2-aminopyridines that coordinate in a strained $\eta^{2}$ binding mode, ${ }^{2}$ are amido type ligands that have received a lot of attention within the last decade. Meanwhile stable complexes for nearly all transition metals could be synthesized emphasizing the very general applicability of the ligand class. ${ }^{3}$ Rather close related ligands are amidinates, guanidinates, and NacNac ligands (Scheme 1). 
Scheme 1. Aminopyridinates (top, left) and the closely related amidinates (top, right), guanidinates (bottom, left), and NacNac ligands (bottom, right). R and R' denote substituents like alkyl, aryl, and alkylsilyl moieties.

The coordination chemistry of the aminopyridinato ligands is summarized until 2003. ${ }^{1}$ The ligands used until then were mainly rather low regarding their steric bulk and not very well suited to stabilize highly reactive neutral or cationic organo rare earth ${ }^{4}$ complexes. In consequence, new types of aminopyridinato ligands that incorporate a number of 2,6dialkylphenyl substituents on the ligand backbone were developed. ${ }^{5}$ The ligand periphery can be readily modified and these very bulky ligands should be utilized in probing key issues in amido lanthanoid and early transition metal catalysts such as deleterious ligand redistribution reactions (as have commonly thwarted lanthanide amide chemistry) and active site monomerdimer pre-equilibria. The ligands are synthesized in a two step procedure - first, a nickel complex catalyzed Grignard (Kumada-type) coupling reaction, followed by Pd catalyzed aryl amination chemistry (Scheme 2).<smiles>[2H]c1cc([2H])c(Br)c(Br)c1</smiles>

\section{1. $\mathrm{Mg}$}

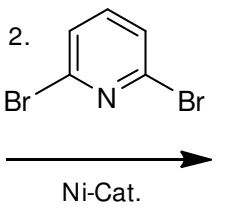<smiles>[R]c1cc([B])c(-c2cccc(Br)n2)c(Br)c1</smiles><smiles>[R]c1cc([R])c(-c2cccc(Br)n2)c([R])c1</smiles><smiles>[R7]c1cccc([R16])c1N</smiles><smiles>[Z]c1cc([R])c(-c2cccc(Nc3c([R])cccc3Br)n2)c([R])c1</smiles>

Scheme 2. Synthesis of very bulky aminopyridines (R, R' and R" = alkyl substituents).

The bulkiest aminopyridine synthesized so far is N-(2,6-diisopropylphenyl)-6-(2,4,6triisopropylphenyl)pyridin-2-amine $\left(=\mathrm{Ap}^{*}-\mathrm{H}\right)$. The steric demand of the Ap* ligand is large. 
The maximum atom-to-atom distance in $\mathrm{Ap}^{*}$ is $15 \AA$ (a in Scheme 3 ) and approximately perpendicular to it about $\mathrm{b}=8 \AA$ ( $\mathrm{b}$ in Scheme 3 ). Comparing this distances with these of the bulky $\eta^{5}$-coordinated $\mathrm{Cp}^{*}$ ligand which has a distance of $\mathrm{a}=\mathrm{b}=6.2 \AA$ for both directions, indicates that $\mathrm{Ap}^{*}$ and related ligands carrying other $\mathrm{R}$ groups should be effective for the protection of large metal ions.

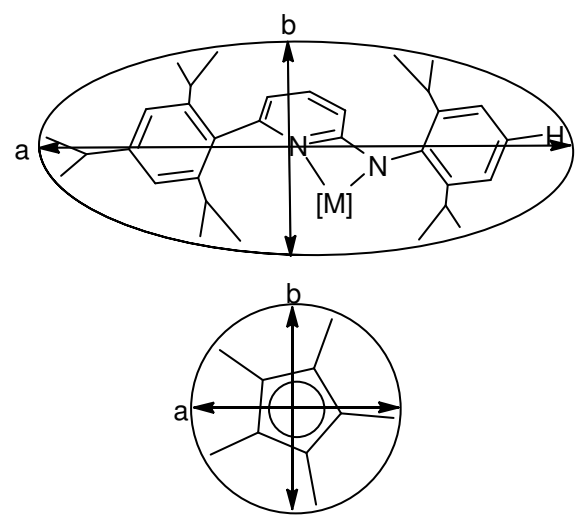

Scheme 3. Description of the steric demand of deprotonated $\mathrm{Ap}^{*}-\mathrm{H}$ in comparison to $\mathrm{Cp}^{*}$.

In consequence, it was thought these ligands might be ideal to stabilize highly reactive rare earth complexes which could also be useful polymerization catalysts. Especially interesting could be the fine tuning opportunity of the catalysts selectivity and activity by using the 17 rare earth ions available with only (slightly) different ionic radii and characteristics resulting from these differences.

In this review the state of the art of rare earth polymerization catalysts stabilized by bulky aminopyridinato ligands is summarized.

\section{Synthesis and Structure of Mono-Ap Halide Complexes}

The steric bulk of the Ap* ligand allows the selective synthesis of mono-Ap complexes even for the early lanthanoids. For instance, the salt metathesis reaction between the potassium salt of $\mathrm{Ap}^{*}-\mathrm{H}$ and $\mathrm{NdCl}_{3}$ gives $\left[\mathrm{Ap} * \mathrm{Nd}(\mathrm{thf})_{2} \mathrm{Cl}_{2}\right]_{2}$ in about $50 \%$ isolated yield of greenish lightblue crystals (Scheme 4). ${ }^{6}$ Interestingly, the reaction of a 2 to 1 ratio of $\mathrm{Ap}^{*} \mathrm{~K}$ to $\mathrm{NdCl}_{3}$ did result in the formation of the same compound. 


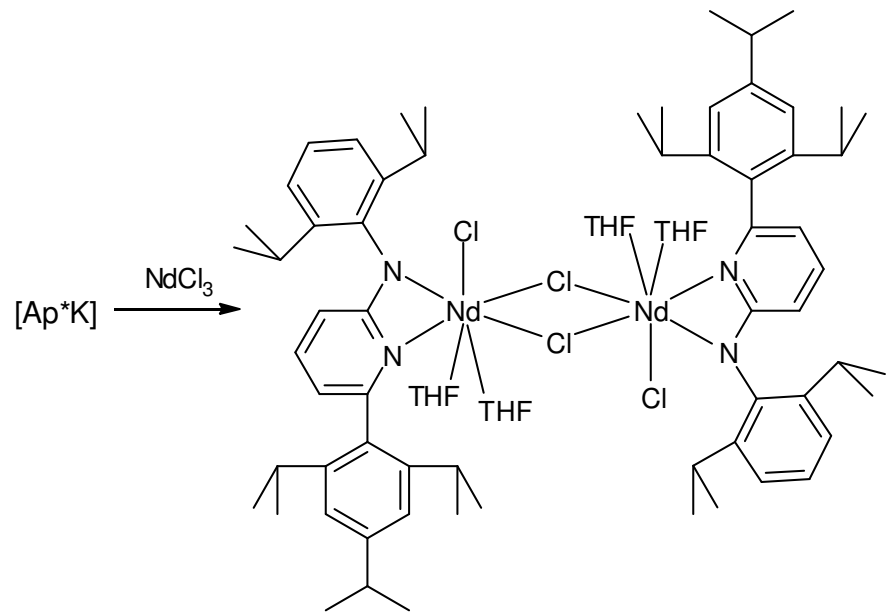

Scheme 4. Synthesis of $\left[\mathrm{Ap} * \mathrm{Nd}(\operatorname{thf})_{2} \mathrm{Cl}_{2}\right]_{2}$.

[Ap* $\mathrm{La}\left(\mathrm{thf}_{3} \mathrm{Br}_{2}\right.$ ] is accessible selectively via salt elimination as well. A comparison of the structure of this dibromide with a closely related amidinate $\left[\mathrm{Am} * \mathrm{La}(\mathrm{thf})_{3} \mathrm{Br}_{2}\right](\mathrm{Am} *-\mathrm{H}=\mathrm{N}, \mathrm{N}-$ bis-(2,6-diisopropylphenyl)-benzamidine) which was synthesized the same way revealed a similar overall primary coordination site bulkiness for both ligands and distinct differences regarding this bulkiness for different directions. A better shielding of the second coordination sphere was observed for the aminopyridinate. ${ }^{7}$ Interestingly, if a aminopyridinato ligand with a slightly smaller steric demand namely $\mathrm{Ap}+\{\mathrm{Ap}+\mathrm{H}=$ (2,6-diisopropylphenyl)-[6-(2,6dimethylphenyl)pyridin-2-yl]-amine the salt elimination reaction of the potassium salt of Ap+-H leads with $\mathrm{NdCl}_{3}$ selectively to bis-Ap complexes (Scheme 5). ${ }^{6}$

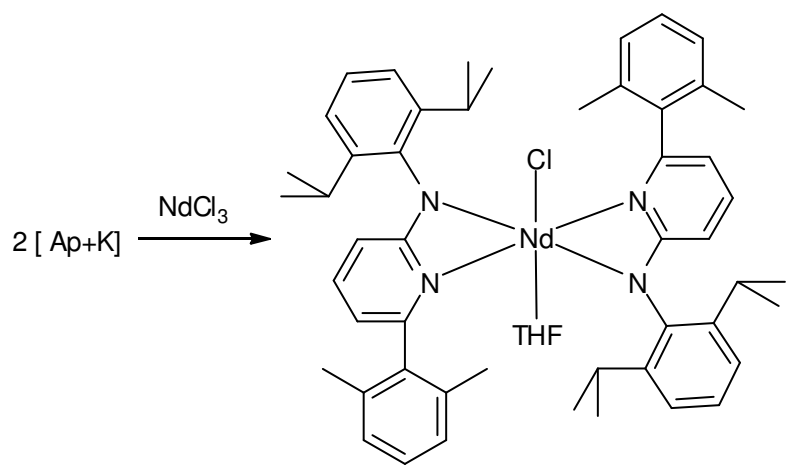

Scheme 5. Synthesis of $\left[\mathrm{Ap}+{ }_{2} \mathrm{Nd}(\mathrm{thf}) \mathrm{Cl}\right]$. 


\section{Alkylation and Hydride Formation of the Bis-Ap Complexes}

The activation of $\mathrm{C}-\mathrm{H}$ bonds and especially the activation of inert alkyls by transition metal or lanthanoid complexes is of a general interest due to its relevance for the functionalization of organic molecules. ${ }^{8}$ Complexes of the rare earth metals are strong Lewis acids which may attack the electron density of $\mathrm{C}-\mathrm{H}$ bonds, thus forming agostic ${ }^{9}$ interactions and activate $\mathrm{C}-\mathrm{H}$ bonds. It was even shown that methane could be activated by lanthanocene complexes such as $\left[\mathrm{Cp}_{2}{ }_{2} \mathrm{LuCH}_{3}\right] .{ }^{10}$ In consequence, intermolecular alkyl group $\mathrm{C}-\mathrm{H}$ activation of spectator ligands of lanthanoid complexes has been observed for a variety of ligands, for instance, for methyl groups of the $\mathrm{Cp}^{*}$ ligand $^{11}$ as well as for alkyl groups of ligands in non-metallocene lanthanoid complexes. ${ }^{12}$

The reaction $[\mathrm{Ap}+\mathrm{K}]$ with $\mathrm{YCl}_{3}$ proceeds selectively as the reaction with $\mathrm{NdCl}_{3}$ (Scheme 4) towards an Bis-Ap complex $\left[\mathrm{Ap}+{ }_{2} \mathrm{Y}(\mathrm{thf}) \mathrm{Cl}\right]$. It can be alkylated with $\left[\mathrm{LiCH}_{2} \mathrm{SiMe}_{3}\right]$ to give rise to the corresponding monoalkyl $\left[\mathrm{Ap}+{ }_{2} \mathrm{Y}(\mathrm{thf}) \mathrm{CH}_{2} \mathrm{SiMe}_{3}\right]$ (molecular structure Figure 1 left).

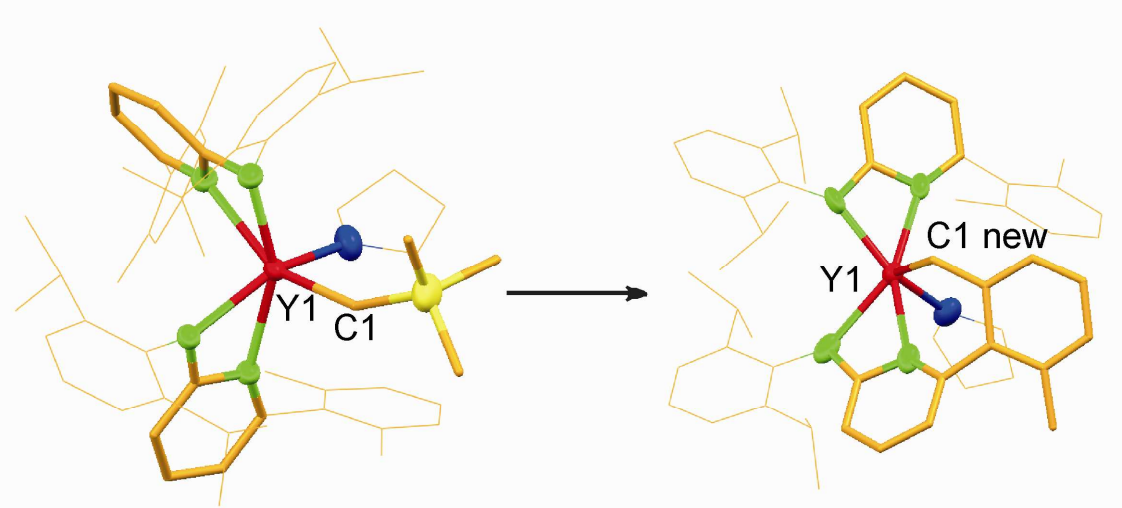

Figure 1. C-H activation of one of the methyl groups of $\mathrm{Ap}+$ in $\left[\mathrm{Ap}+{ }_{2} \mathrm{Y}(\mathrm{thf}) \mathrm{CH}_{2} \mathrm{SiMe}_{3}\right]$.

Interestingly, $\left[\mathrm{Ap}{ }_{2} \mathrm{Y}(\mathrm{thf}) \mathrm{CH}_{2} \mathrm{SiMe}_{3}\right](\mathrm{Me}=$ methyl $)$ is not stable and undergoes a $\mathrm{C}-\mathrm{H}$ activation of one of the methyl groups of one of the Ap+ ligands. This intra-molecular $\mathrm{C}-\mathrm{H}$ activation seems entropically favoured and follows a first-order kinetic. ${ }^{13}$ The corresponding hydride $\left[\mathrm{Ap}+{ }_{2} \mathrm{Y}(\mathrm{thf}) \mathrm{H}\right]$, generated by the reaction of the $\left[\mathrm{Ap}+{ }_{2} \mathrm{Y}(\mathrm{thf}) \mathrm{CH}_{2} \mathrm{SiMe}_{3}\right]$ with $\mathrm{PhSiH}_{3}$ $(\mathrm{Ph}=$ phenyl $)$ undergoes an intramolecular metallation reaction very fast at room temperature. Intramolecular $s p^{3}$-hybridized C-H activation of a hydride can be more than 500 times faster than that of an alkyl as judged by comparing the half times of the decomposition reactions (Scheme 6). 


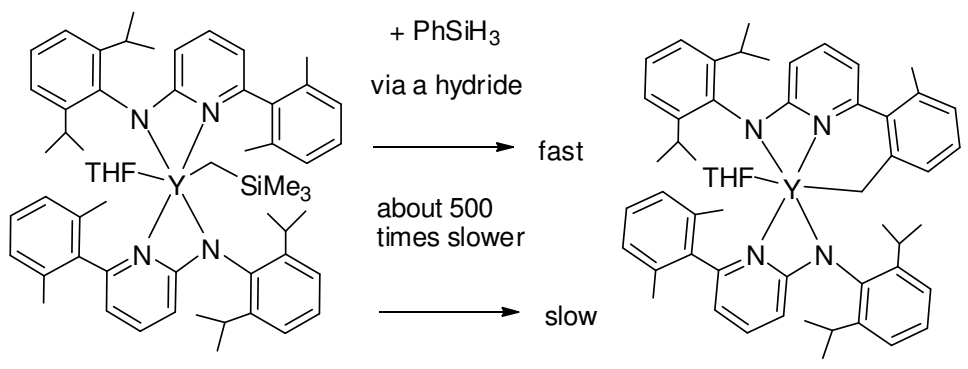

Scheme 6. Rates of C-H activation alkyl via transient hydride.

It was thought that this type of $\mathrm{C}-\mathrm{H}$ activation should also proceed for the lanthanoids and due to their difference in size (ionic radii) one should see distinct differences in the rate of this reaction. Some general conclusions how the size of the lanthanoid ion influences the rate of a reaction (here a C-H activation reaction which importance was given briefly at the beginning of this chapter) might be drawn. The following observations have been made. ${ }^{14}$

$\left[\mathrm{Ap}+{ }_{2} \mathrm{Sc}(\right.$ thf $\left.) \mathrm{CH}_{2} \mathrm{SiMe}_{3}\right]$ : The Sc alkyl is very stable and doesn't show any detectable decomposition when its $\mathrm{C}_{6} \mathrm{D}_{6}$ solution was monitored for several weeks. If it is reacted with $\mathrm{PhSiH}_{3}$ no conversion neither hydride formation nor C-H activation is observed.

$\left[\mathrm{Ap}+{ }_{2} \mathrm{Lu}\right.$ (thf) $\left.\mathrm{CH}_{2} \mathrm{SiMe}_{3}\right]$ : The alkyl converts very slowly at room temperature towards the C$\mathrm{H}$ activation product. Stirring of the $\mathrm{Lu}$ alkyl in toluene with $\mathrm{PhSiH}_{3}$ for three days at room temperature allowed the isolation of its $\mathrm{C}-\mathrm{H}$ activation product in $60 \%$ yield.

$\left[\mathrm{Ap}+{ }_{2} \mathrm{Ln}(\mathrm{thf}) \mathrm{CH}_{2} \mathrm{SiMe}_{3}\right](\mathrm{Ln}=\mathrm{Nd}, \mathrm{La})$ : In contrast to $\mathrm{Sc}$ and $\mathrm{Lu}$ the alkylation of the chloro complexes $\left[\mathrm{Ap}+{ }_{2} \mathrm{Ln}(\mathrm{thf}) \mathrm{Cl}\right]$ of the larger lanthanoid ions $\mathrm{La}$ and $\mathrm{Nd}$ with one equivalent of $\left[\mathrm{LiCH}_{2} \mathrm{SiMe}_{3}\right]$ did not yield the desired alkyl complexes $\left[\mathrm{Ap}+{ }_{2} \mathrm{Ln}(\mathrm{thf}) \mathrm{CH}_{2} \mathrm{SiMe}_{3}\right]$ and led directly to the intramolecular C-H bond activated products in isolated yields of around $60 \%$. $\mathrm{C}-\mathrm{H}$ activation of the alkyl already proceeds to fast to isolate it.

\section{Alkylation and Hydride Formation of the Mono-Ap Complexes}

The selective formation of mono-Ap dihalide complexes if the Ap* ligand is used ${ }^{6}$ (Scheme 4) may also allow to synthesize dialkys selectively. Two routes can be employed: salt metathesis ${ }^{15}$ and alkane elimination, ${ }^{16}$ as shown for $\mathrm{Y}$ and $\mathrm{Lu}$ (Scheme 7). 
Alkane elimination is highly efficient and affords very good yield of the dialkyls. Unfortunately, it is difficult to isolate the starting material for the early lanthanoids. Salt metathesis can be employed throughout the whole series but usually affords lower yields. These dialkyls are stable and do not undergo C-H activation reactions of any of the methyl groups of the aminopyridinato ligand. They react with $\mathrm{H}_{2}$ and $\mathrm{PhSiH}_{3}$ selectively and form polynuclear hydride alkyl compounds (Scheme 8$){ }^{15}$

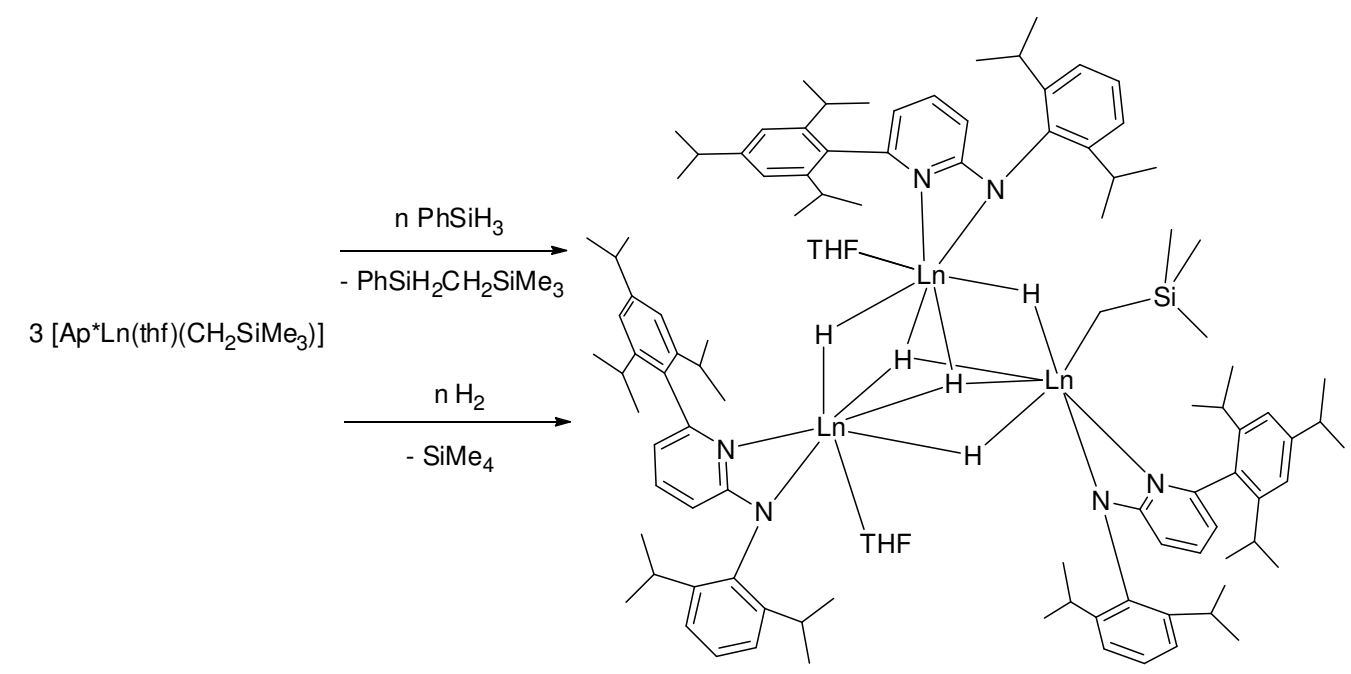

Scheme 8 . Synthesis of polynuclear hydride alkyl compounds.

Molecular rare earth metal hydrides are a fascinating class of compounds that posses a variety of unique structural and chemical properties. ${ }^{17}$ Assembly of trinuclear tetrahydride rare earth ate species $\left\{\left[\mathrm{Cp}_{2} \mathrm{LnH}\right]_{3} \mathrm{H}\right\}\left\{\mathrm{Li}(\text { thf })_{4}\right\}$ was reported already in the early $1980 \mathrm{~s}^{18}$ The first 
"mono(cyclopentadienyl) dihydrido" complexes were reported in $1999^{19}$ and the area started blooming in $2001 .{ }^{20}$ Meanwhile structural data obtained via neutron diffraction gave a very reliable picture of the $\mathrm{H}$ atom positions in these molecules. ${ }^{21}$ The hydride alkyl clusters formed by the reaction of mono-Ap stabilized dialkyls had been unique at this time. Usually, pure hydride clusters are formed. ${ }^{17}$ The molecular structure of $\left[(\mathrm{Ap} * \mathrm{Y})_{3}\left(\mu^{2}-\mathrm{H}\right)_{3}\left(\mu^{3}-\right.\right.$ $\left.\left.\mathrm{H})_{2}\left(\mathrm{CH}_{2} \mathrm{SiMe}_{3}\right)(\text { thf })_{2}\right)\right]$ is shown in Figure 2.

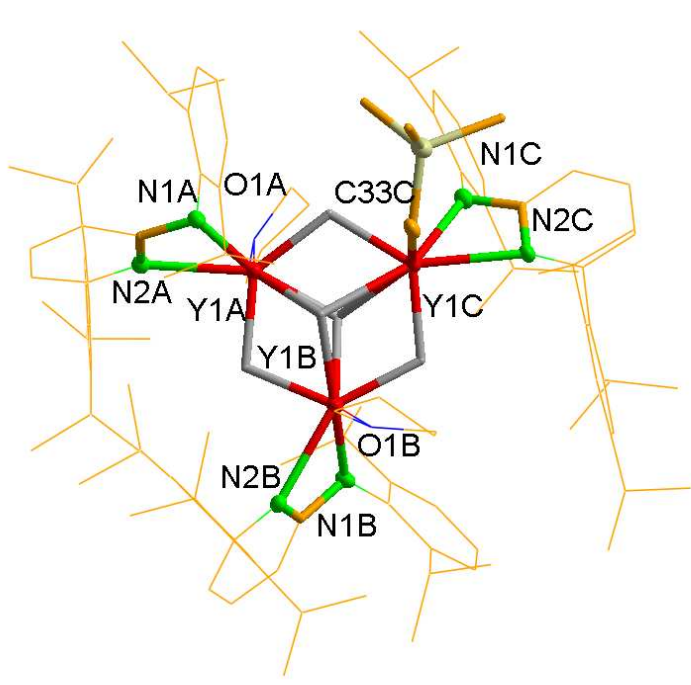

Figure 2. Molecular structure of $\left.\left[(\mathrm{Ap} * \mathrm{Y})_{3}\left(\mu^{2}-\mathrm{H}\right)_{3}\left(\mu^{3}-\mathrm{H}\right)_{2}\left(\mathrm{CH}_{2} \mathrm{SiMe}_{3}\right)(\text { thf })_{2}\right)\right]$. The iPr groups of the Ap* ligands are omitted. Selected bond lengths $[\AA]$ and angles [ $\left.{ }^{\circ}\right]$ : $\mathrm{Y}(1 \mathrm{~A})-\mathrm{N}(1 \mathrm{~A})$ 2.323(2), $\mathrm{Y}(1 \mathrm{~A})-\mathrm{N}(2 \mathrm{~A})$ 2.459(2), $\mathrm{Y}(1 \mathrm{~A})-\mathrm{Y}(1 \mathrm{~B})$ 3.4408(4), $\mathrm{Y}(1 \mathrm{~A})$ - $\mathrm{Y}(1 \mathrm{C})$ 3.5158(4), $\mathrm{Y}(1 \mathrm{~B})-$ N(1B) 2.307(2), Y(1B)-O(1B) 2.3510(19), Y(1B)-N(2B) 2.477(2), Y(1B)-Y(1C) 3.5058(4), $\mathrm{Y}(1 \mathrm{C})-\mathrm{N}(1 \mathrm{C})$ 2.331(2), $\mathrm{Y}(1 \mathrm{C})-\mathrm{C}(33 \mathrm{C})$ 2.402(3), $\mathrm{Y}(1 \mathrm{C})-\mathrm{N}(2 \mathrm{C})$ 2.503(2), $\mathrm{Y}(1 \mathrm{~B})-\mathrm{Y}(1 \mathrm{~A})-\mathrm{Y}(1 \mathrm{C})$ $60.512(8), \mathrm{N}(1 \mathrm{~A})-\mathrm{Y}(1 \mathrm{~A})-\mathrm{N}(2 \mathrm{~A}) \quad 56.70(8), \mathrm{N}(1 \mathrm{~B})-\mathrm{Y}(1 \mathrm{~B})-\mathrm{N}(2 \mathrm{~B})$ 56.64(7)，N(1C)-Y(1C)$\mathrm{N}(2 \mathrm{C}) 56.40(7)$.

\section{Low Valent Lanthanoid Aminopyridinates}

Due to the selective formation of mono- or bis-Ap complexes for the three valent rare earth atoms depending from the steric demand of the Ap ligands a similar selectivity was expected for the two valent lanthanoids. Lanthanoids which a rather stable in the two valent oxidation 
state like $\mathrm{Eu}, \mathrm{Yb}$ and $\mathrm{Sm}$ allow for the selective synthesis of mono-Ap complexes (Scheme 9). ${ }^{6,22}$

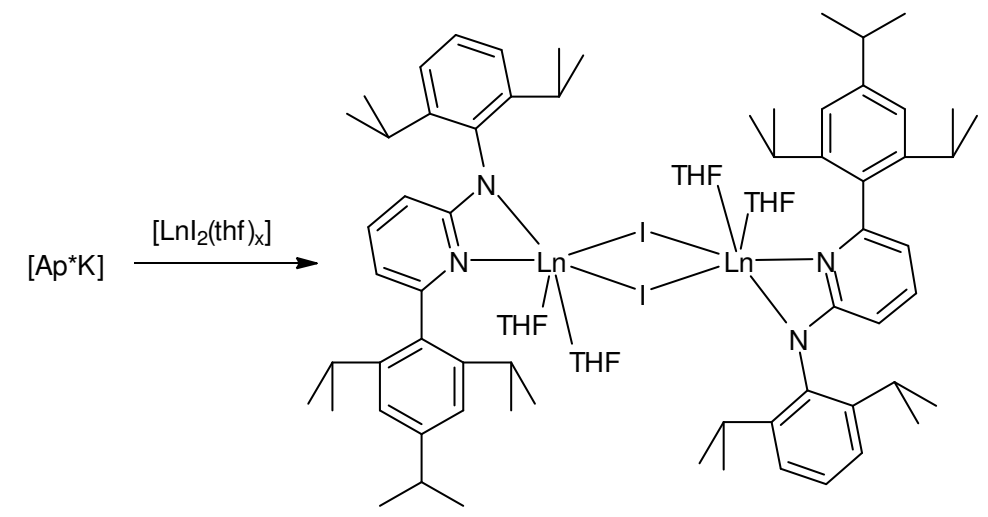

Scheme 9. Synthesis of $\left[A p * \operatorname{Ln}(\operatorname{thf})_{2} I_{2}(\operatorname{Ln}=\mathrm{Sm}, \mathrm{Yb}, \mathrm{Eu})\right.$.

Attempts to reduce $\left[\mathrm{Ap} * \mathrm{Ln}(\mathrm{thf})_{2} \mathrm{I}\right]_{2}(\mathrm{Ln}=\mathrm{Eu}, \mathrm{Yb})$ with the intention to form a unsupported $\mathrm{f}$ element-f-element bond failed. Redistribution products of the type $\left[\mathrm{Ap}{ }_{2} \operatorname{Ln}(\operatorname{thf})_{2}\right]$ were isolated instead. ${ }^{22}$

The "direct reaction" between lanthanoid metal and bulky aminopyridines is an effective and simple way to synthesize truly homoleptic aminopyridinates of $\mathrm{Yb}$. The used "direct reaction" synthetic method ${ }^{23}$ is especially valuable for homoleptic lanthanoid organoamides and phenolates ${ }^{24}$ and has recently been extended to analogous alkaline earth complexes. ${ }^{25}$ Again, the steric demand of the Ap ligand opens and closes different reaction pathways. The use of relatively less bulky Ap-H (Ap-H = N,6-dimesitylpyridin-2-amine) resulted in the formation of a six coordinated trivalent $\mathrm{Yb}$ complex $\left[\mathrm{Ap}_{3} \mathrm{Yb}\right]$ whereas more bulky aminopyridine Ap+$\mathrm{H}$ afforded a low coordinate divalent $\mathrm{Yb}$ compound $\left[\mathrm{Ap}+{ }_{2} \mathrm{Yb}\right](\mathrm{Scheme} 10) .{ }^{26}$ 
$\mathrm{Yb}$

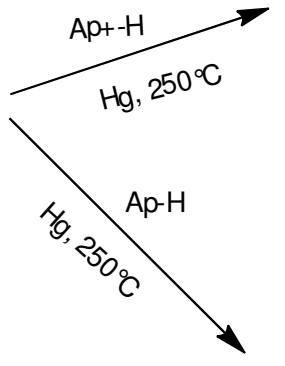

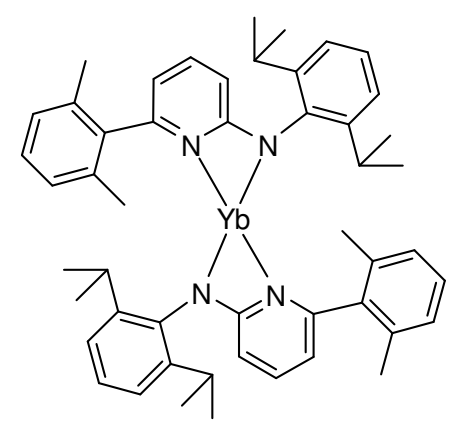

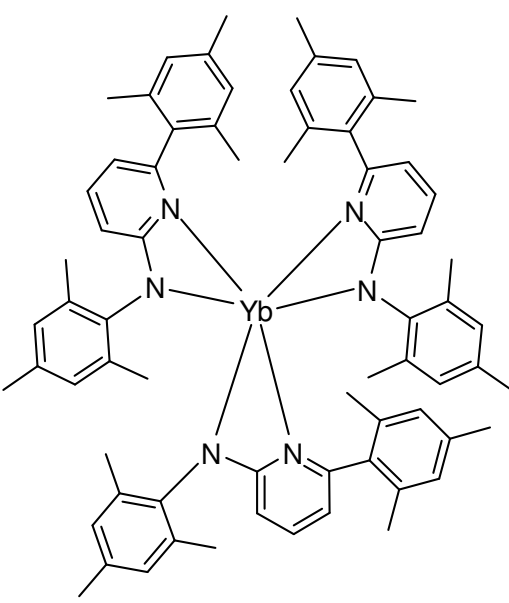

Scheme 10. Synthesis of $\left[\mathrm{Ap}_{3} \mathrm{Yb}\right]$ and $\left[\mathrm{Ap}+{ }_{2} \mathrm{Yb}\right]$.

Compound $\left[\mathrm{Ap}+{ }_{2} \mathrm{Yb}\right]$ is a very low coordinated species and shows an intermolecular $\mathrm{C}_{\text {Aryl }}-\mathrm{H}$ agostic interactions in the solid state (Figure 3).

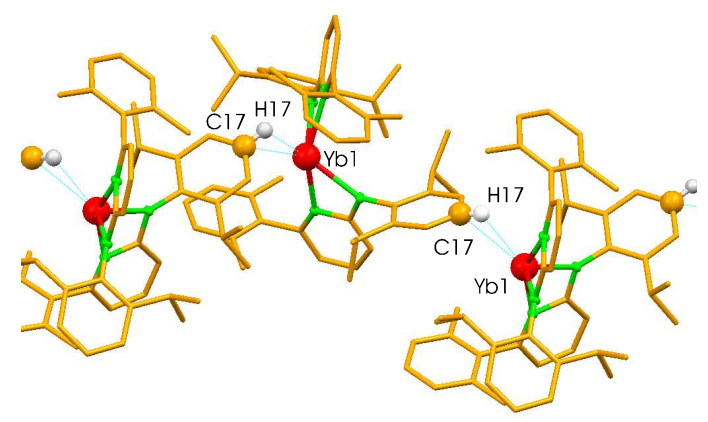

Figure 3. Solid state structure of $\left[\mathrm{Ap}+{ }_{2} \mathrm{Yb}\right]$ showing an intermolecular agostic interactions (Yb1...C17 2.981(2) ̊ and Yb1...H17 distances 2.56(3) ̊). 
Salt metathesis using the potassium salt of the Ap ligand and $\left[\mathrm{YbI}_{2}(\mathrm{thf})_{\mathrm{x}}\right]$ gives rise to other products namely five coordinate $\left[\mathrm{Ap}{ }_{2} \mathrm{Yb}(\right.$ thf $\left.)\right]$ and six coordinate $\left[\mathrm{Ap}{ }_{2} \mathrm{Yb}(\text { thf })_{2}\right] .{ }^{26}$

\section{Di- and Trivalent Rare Earth Aminopyridinates as Initiators in the Ring-Opening Polymerization Reactions of $\varepsilon$-Caprolactone}

Ring-opening polymerization (ROP) is a potent synthetic tool for the synthesis of specific well-defined high molar mass polyesters ${ }^{27}$ and rare earth initiated coordination-insertion ROP has attracted considerable interest. ${ }^{28}$ Research activities on the design of more elaborated and most often more sophisticated rare earth complexes have enabled impressive progress in both the organic catalysis and polymerization chemistry. Much effort nowadays are driven by environmental concerns, getting more and more into the scope of green chemistry and biocompatibility concepts. $^{29}$ Homoleptic trisborohydride rare earth complexes, $\left[\mathrm{Ln}\left(\mathrm{BH}_{3}\right)_{3}(\mathrm{thf})_{3}\right]^{30} \quad(\mathrm{Ln}=$ lanthanide $)$ are efficient initiators for the ring-opening polymerization of $\varepsilon$-caprolactone (CL), such borohydride initiators have subsequently been extended to organometallic derivatives such as $\left[\operatorname{Sm}\left(\mathrm{C}_{5} \mathrm{Me}_{5}\right)_{2}(\mathrm{thf})\right]$ for the polymerization of lactones. ${ }^{31}$ Furthermore, rare earth complexes involving aminopyridinato ligands of low steric demand have been synthesized and evaluated in polymerization of CL with the hope to improve the control of the polymerization process and a linear relation between the monomer to intiator ratio and the molecular weight of the polymer was observed. ${ }^{32}$ Ring-opening polymerization of $\varepsilon$-caprolactone initiated by complexes like $\left[\mathrm{Ap} * \mathrm{La}(\mathrm{thf})_{3} \mathrm{Br}_{2}\right]$ or $\left[\mathrm{Ap} * \mathrm{Yb}(\text { thf })_{2} \mathrm{I}\right]_{2}$ in the presence of $\mathrm{NaBH}_{4}$ allowing the preparation, in a controlled process and in a short reaction time, of $\alpha, \omega$-dihydroxytelechelic polymers with high molar mass ( $\overline{\mathrm{M}}$ n up to 50000$)$ and moderate molar mass distributions $(1.3<\overline{\mathrm{M}} \mathrm{w} / \overline{\mathrm{M}} \mathrm{n}<1.6){ }^{33}$ 
Table 1. Polymerization of $\varepsilon-\mathrm{CL}$ in THF at $23^{\circ} \mathrm{C}$ over 4 hours using [Ap*La(thf $)_{3} \mathrm{Br}_{2}$ ].

\begin{tabular}{|c|c|c|c|c|c|c|c|c|c|}
\hline $\begin{array}{c}{\left[\mathrm{NaBH}_{4}\right]_{0}} \\
/[\text { Initiator }]_{0}\end{array}$ & $\begin{array}{c}{\left[{\text { Initiator }]_{0}{ }^{a}}\right.} \\
\left(\text { mmol.L }^{-1}\right)\end{array}$ & $\begin{array}{c}{\left[\mathrm{BH}_{4}\right]_{0}} \\
\left(\mathrm{mmol}^{-L^{-1}}\right)\end{array}$ & $\begin{array}{c}{[\varepsilon-\mathrm{CL}]_{0}} \\
\left(\mathrm{mmol}^{-\mathbf{L}^{-1}}\right)\end{array}$ & $\begin{array}{c}{[\varepsilon-\mathrm{CL}]_{0} /} \\
{\left[\mathrm{BH}_{4}\right]_{0}{ }^{a}}\end{array}$ & $\begin{array}{c}\text { Monomer } \\
\text { Conv. }^{b} \\
(\%)\end{array}$ & $\begin{array}{c}\overline{\mathrm{Mn}} \text { theo } \\
\left(\mathrm{g}^{c} \mathrm{~mol}^{-1}\right)\end{array}$ & $\begin{array}{c}\overline{\text { Mn SEC }}{ }^{d} \\
\left(\text { g.mol }^{-1}\right)\end{array}$ & $\begin{array}{c}\bar{M}{ }_{\text {NMR }}{ }^{\text {f }} \\
\left(\text { g.mol }^{-1}\right)\end{array}$ & $\overline{\mathbf{M}}_{\mathbf{w}} / \overline{\mathbf{M}}^{e}$ \\
\hline$\overline{0}$ & 7.6 & 0 & 410.2 & 54 & 85 & 5200 & 167600 & - & 1.4 \\
\hline 0 & 3.8 & 0 & 410.2 & 108 & 90 & 11100 & 168600 & - & 1.5 \\
\hline 1.0 & 9.6 & 9.3 & 1002 & 108 & 99 & 12200 & 16000 & 18900 & 1.3 \\
\hline 1.0 & 8.9 & 8.8 & 1002 & 114 & 98 & 12700 & 15700 & 19000 & 1.3 \\
\hline 2.0 & 5.4 & 10.0 & 4500 & 450 & 99 & 50800 & 46300 & 45600 & 1.5 \\
\hline 3.0 & 2.5 & 7.9 & 722.0 & 91 & 97 & 10050 & 17000 & 15700 & 1.4 \\
\hline
\end{tabular}

Table 2. Polymerization of $\varepsilon$-CL in THF at $23^{\circ} \mathrm{C}$ over 4 hours using $\left[\mathrm{Ap} * \mathrm{Yb}(\mathrm{thf})_{2} \mathrm{I}\right]_{2}$.

\begin{tabular}{|c|c|c|c|c|c|c|c|c|c|}
\hline $\begin{array}{c}{\left[\mathrm{NaBH}_{4}\right]_{0}} \\
/[\text { Initiator }]_{0}\end{array}$ & $\begin{array}{l}{\text { [Initiator }]_{0}{ }^{a}} \\
\left(\text { mmol. }^{-1}\right)\end{array}$ & 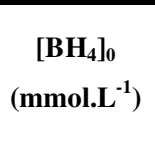 & $\begin{array}{c}{[\varepsilon-\mathrm{CL}]_{0}} \\
\left(\mathrm{mmol}^{-1} \mathrm{~L}^{-1}\right)\end{array}$ & $\begin{array}{c}{[\varepsilon-\mathrm{CL}]_{0} /} \\
{\left[\mathrm{BH}_{4}\right]_{0}{ }^{a}}\end{array}$ & $\begin{array}{c}\text { Monomer } \\
\text { Conv. }^{b} \\
(\%)\end{array}$ & $\begin{array}{c}\bar{M}_{\text {theo }}{ }^{c} \\
\left(\text { g.mol }^{-1}\right)\end{array}$ & $\begin{array}{c}\overline{\mathbf{M n}}{ }_{\text {SEC }}{ }^{d} \\
\left(\mathrm{~g} \cdot \mathbf{m o l}^{-1}\right)\end{array}$ & $\begin{array}{l}\bar{M}_{\text {NMR }}{ }^{\mathbf{f}} \\
\left(\text { g.mol }^{-1}\right)\end{array}$ & $\overline{\mathbf{M}}_{\mathbf{w}} / \overline{\mathbf{M}}^{e}$ \\
\hline 0 & 4.2 & 0 & 410.2 & 98 & 85 & 9500 & 121700 & - & 1.7 \\
\hline 0 & 2.1 & 0 & 410.2 & 195 & 75 & 16700 & 128200 & - & 1.7 \\
\hline 2.1 & 4.8 & 9.9 & 1120 & 113 & 98 & 12600 & 34500 & 29000 & 1.6 \\
\hline 2.0 & 3.2 & 6.6 & 1120 & 170 & 98 & 19000 & 47500 & 35000 & 1.6 \\
\hline 4.0 & 4.2 & 16.9 & 1002 & 59 & 98 & 6600 & 13000 & 22000 & 1.5 \\
\hline 4.0 & 4.2 & 16.9 & 2000 & 118 & 98 & 13200 & 23000 & 28500 & 1.5 \\
\hline 4.0 & 2.5 & 9.5 & 5400 & 568 & 98 & 63400 & 43600 & 45600 & 1.6 \\
\hline
\end{tabular}


Table 3. Polymerization of $\varepsilon$-CL in THF at $23^{\circ} \mathrm{C}$ over 4 hours using [Ap* $\mathrm{Lu}(\text { thf })_{2} \mathrm{Cl}_{2}$ ].

\begin{tabular}{|c|c|c|c|c|c|c|c|c|c|}
\hline $\begin{array}{c}{\left[\mathrm{NaBH}_{4}\right]_{0}} \\
/[\text { Initiator }]_{0}\end{array}$ & $\begin{array}{c}{[\text { Initiator }]_{0}{ }^{a}} \\
\left(\mathrm{mmol}^{\left.-\mathrm{L}^{-1}\right)}\right.\end{array}$ & $\begin{array}{c}{\left[\mathrm{BH}_{4}\right]_{0}} \\
\left(\mathrm{mmol}^{-1} \mathbf{L}^{-1}\right.\end{array}$ & $\begin{array}{c}{[\varepsilon-\mathrm{CL}]_{0}} \\
\left(\mathrm{mmol}^{-1} \mathbf{L}^{-1}\right)\end{array}$ & $\begin{array}{c}{[\varepsilon-\mathrm{CL}]_{0} /} \\
{\left[\mathrm{BH}_{4}\right]_{0}{ }^{a}}\end{array}$ & $\begin{array}{c}\text { Monomer } \\
\text { Conv. }^{b} \\
(\%)\end{array}$ & $\begin{array}{c}\overline{\mathrm{M}}{ }^{c}{ }^{c} \\
\left(\mathrm{~g} . \mathrm{mol}^{-1}\right)\end{array}$ & $\begin{array}{c}\overline{M n}_{\text {SEC }}{ }^{d} \\
(\text { g.mol } \\
\end{array}$ & $\begin{array}{c}\overline{M n}_{\text {NMR }}{ }^{\mathbf{f}} \\
(\text { g.mol }\end{array}$ & $\overline{\mathbf{M}}_{\mathbf{w}} / \overline{\mathbf{M}}^{e}$ \\
\hline 0 & 8.8 & 0 & 410.2 & 47 & 45 & 2400 & - & - & - \\
\hline 0 & 4.8 & 0 & 410.2 & 85 & 33 & 3200 & - & - & - \\
\hline 1.0 & 9.7 & 9.9 & 902.5 & 91 & 100 & 10400 & 17600 & 20700 & 1.6 \\
\hline 1.1 & 6.1 & 6.6 & 902.4 & 137 & 98 & 15300 & 16400 & 12500 & 1.5 \\
\hline 2.0 & 5.4 & 10.0 & 4500 & 450 & 99 & 50800 & 45600 & 51800 & 1.6 \\
\hline
\end{tabular}

${ }^{a}\left[[\text { nitiator }]_{0}=\left[\mathrm{Ap} * \mathrm{La}(\text { thf })_{3} \mathrm{Br}\right]_{0} ;\left[\mathrm{Ap} * \mathrm{Lu}\left(\text { thf }_{2}\right)_{2} \mathrm{Cl}_{2}\right]_{0}\right.$ or $\left[\left[\mathrm{Ap} * \mathrm{Yb}\left(\mathrm{thff}_{2}\right]_{2}\right]_{2}\right]_{0}$; in absence of $\mathrm{NaBH}_{4},\left[\varepsilon-\mathrm{CL}_{0} /\left[\mathrm{BH}_{4}\right]_{0}\right.$ $=[\varepsilon-\mathrm{CL}]_{0} /[\text { Initiator }]_{0} ;{ }^{b}$ Calculated from ${ }^{1} \mathrm{H}$ NMR analysis; ${ }^{c}$ Calculated with $\overline{\mathrm{M}}_{\text {(theo) }}=[\varepsilon-\mathrm{CL}]_{0} /\left[\mathrm{BH}_{4}\right]_{0} \times 114 \mathrm{x}$ conversion; ${ }^{d} \mathrm{SEC}$ values of precipitated polymer samples corrected with the coefficient 0.56 ; ${ }^{\circ}$ Molar mass distribution calculated from SEC chromatogram traces; ${ }^{\mathrm{f}}$ Molar masses determined by NMR.

In presence of more than one equivalent of $\mathrm{NaBH}_{4}$ per metal centre, the polymerization proceeds smoothly as well and it is quite controlled especially for $\mathrm{Lu}$ and $\mathrm{La}$. The experimental molar masses $\overline{\mathrm{M}} \mathrm{n}_{\mathrm{SEC}}$ and $\overline{\mathrm{M}} \mathrm{n}_{\mathrm{NMR}}$ give similar values and they are often in quite close agreement with the theoretical values ( $\overline{\mathrm{M}} \mathrm{n}_{\text {theo }}$ ). NMR analyses of the polymers recovered from the reactions done in the presence of $\mathrm{NaBH}_{4}$ showed the formation of $\alpha, \omega$ dihydroxytelechelic PCL. ${ }^{33}$ These results are indicative of a $\mathrm{Ln}^{-\mathrm{BH}_{4}}$ bond which becomes the active site of the polymerization. It is interesting to mention that it was not possible to isolate the resulting borohydride compound from the reaction of $\left[\mathrm{Ap} * \mathrm{La}(\mathrm{thf})_{3} \mathrm{Br}_{2}\right]$ or [Ap* $\mathrm{Lu}(\text { thf })_{2} \mathrm{Cl}_{2}$ ] with $\mathrm{NaBH}_{4}$ or $\mathrm{KBH}_{4}$. Due to the formation of $\alpha, \omega$-dihydroxytelechelic PCL a metal-alkoxide intermediate, where the $\mathrm{HBH}_{3}$ end group reduces the $\alpha$-carbonyl function is likely to be the initiating species ([Ln]- $\left\{\mathrm{O}\left(\mathrm{CH}_{2}\right)_{5} \mathrm{CH}_{2} \mathrm{OBH}_{\mathrm{x}}\right\}$ ). After the termination reaction, both the $\mathrm{Ln}-\mathrm{O}$ and the $-\mathrm{CH}_{2} \mathrm{OBH}_{\mathrm{x}}$ extremities are hydrolyzed into hydroxyl chain ends giving rise to a polymer that can be formulated as $\left[\mathrm{HO}\left(\mathrm{CH}_{2}\right)_{5} \mathrm{C}(\mathrm{O})\left\{\mathrm{O}\left(\mathrm{CH}_{2}\right)_{5} \mathrm{C}(\mathrm{O})\right\}_{\mathrm{n}-2} \mathrm{O}\left(\mathrm{CH}_{2}\right)_{6} \mathrm{OH}\right]$, HO-PCL-OH.

\section{Coordinative Chain Transfer Polymerization (CCTP) of Ethylene}

\section{Introduction}

The polymerization of ethylene especially in the low molecular weight range can be established in a highly controlled fashion by a chain growing process on a main group metal 
or zinc which is catalyzed by an organo transition metal or lanthanide complex - Coordinative Chain Transfer Polymerization (CCTP, Scheme 12). ${ }^{37}$ Chain growing takes place via ethylene insertion into the transition metal or lanthanide $\left[\mathrm{M}^{1}\right]$ carbon bond. The fast transferred chains "rest" at the main group or zinc centre $\left[\mathrm{M}^{2}\right]$ where chain termination processes like $\beta-\mathrm{H}$ transfer/elimination are of low significance.

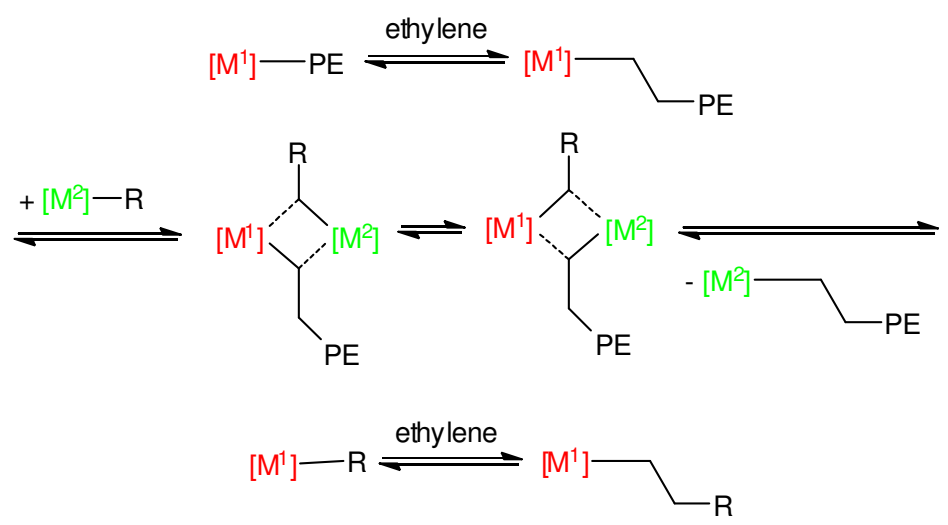

Scheme 12. CCTP.

Such a strategy appeared in the patent literature in the early 90s. A variety of metallocene based catalyst systems which catalyzed chain growing at $\mathrm{Al}$ alkyls were described. ${ }^{38}$ The first highly controlled catalyst system (rare earth/magnesium based) was introduced a few years later. ${ }^{39}$ Meanwhile a variety of catalysts that undergo CCTP is known. ${ }^{37,38,39,40,42,44,55}$ The equilibrium between chain transfer state (CTS) and chain growing state (CGS) is the basis of such a polymerization protocol and determines the overall productivity (Scheme 13). The CTS is essentially responsible for a very fast intra- [exchange of dashed and solid lines within the CTS (Scheme 12)] and intermolecular [exchange of MGM(R)(R')(R') units of the CTS] chain transfer. The CGS accomplishes the growing of a single chain. To achieve high control the chain transfer has to be faster than chain growing to avoid multiple insertions. If an excess of $\operatorname{MGM}(\mathrm{R})\left(\mathrm{R}\right.$ ') $\left(\mathrm{R}^{\prime \prime}\right)$ is present and if other chain termination processes like $\beta-H$ transfer/elimination could be suppressed for the CGS a chain growing of all chains of all $\operatorname{MGM}(\mathrm{R})(\mathrm{R}$ ')(R') molecules with nearly the same rate is observed (MGM = main group metal, or $\mathrm{Zn}$ ). Consequently, a very narrowly distributed MGM terminated PE material is observed. 


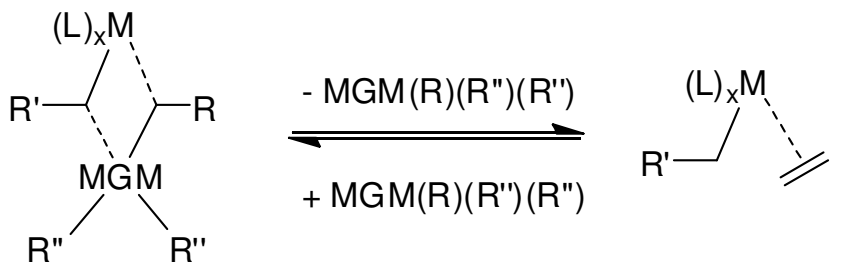

Scheme 13. Basic CCTP equilibrium: left: chain transfer state (CTS); right: chain growing state $(\mathrm{CGS}), \mathrm{M}=$ transition metal or lanthanide, $\mathrm{MGM}=$ main group metal or $\mathrm{Zn}$, not necessarily three valent).

\section{The Ap Organoyttrium Cation Aluminum Catalyst System}

We had studied the polymerization of ethylene using organoyttrium cations ${ }^{41}$ as catalysts. These cations can be generated by following the procedure shown in Scheme $14 .{ }^{42}$

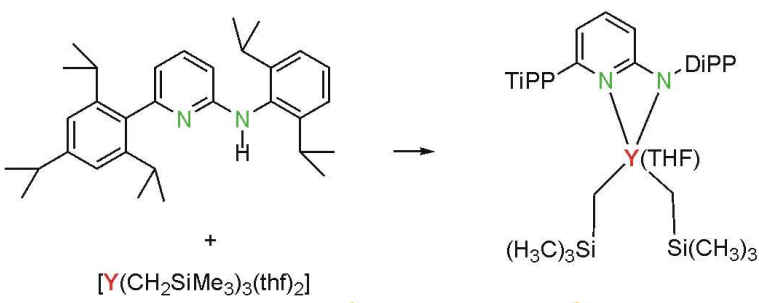

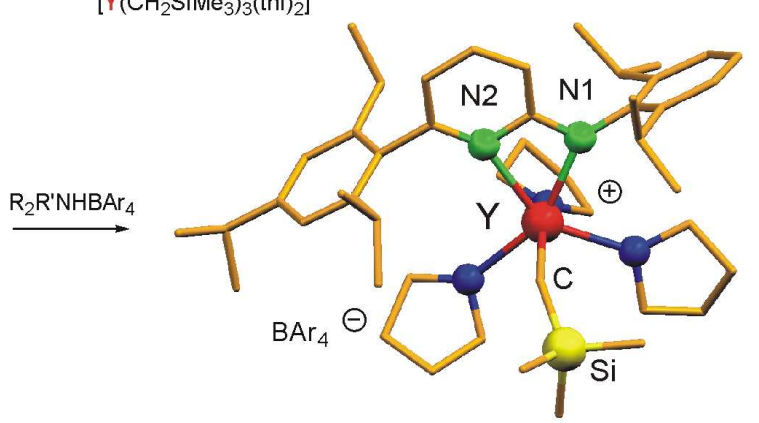

Scheme 14. Synthesis and molecular structure of $\left\{\left[\mathrm{Ap} * \mathrm{Y}(\mathrm{thf})_{3} \mathrm{CH}_{2} \mathrm{SiMe}_{3}\right]^{+}\left[\mathrm{B}\left(\mathrm{C}_{6} \mathrm{~F}_{5}\right)_{4}\right]^{-}\right\}$. The anion is simplified. Two independent cations per asymmetric unit were found; selected bond parameters [Å, $\left.{ }^{\circ}\right]$ averaged: Y-N1 2.302(3), Y-N2 2.421(3), Y-C 2.382(4), N1-Y-N2 57.41(11) Y-C-Si 143.8 (2).

For ethylene polymerization experiments the ammonium borate $\left[\mathrm{R}_{2} \mathrm{~N}\left(\mathrm{CH}_{3}\right) \mathrm{H}\right]^{+}\left[\mathrm{B}\left(\mathrm{C}_{6} \mathrm{~F}_{5}\right)_{4}\right]^{-}(\mathrm{R}$ $\left.=\mathrm{C}_{16} \mathrm{H}_{31}-\mathrm{C}_{18} \mathrm{H}_{35}\right)$ and a Y/B ratio of $1 / 1.1$ were used. A comparison of the ethylene polymerization activity revealed that the steric bulk of the ligand is crucial (Table 4). 
If $\mathrm{Ap}^{*}$ is used to generate the organoyttrium cation catalyst the activity is the highest and for $\mathrm{Ap}^{+}$and $\mathrm{Ap}^{-}$(both ligands contain the inverse substitution pattern and the steric bulk could be considered as similar- Scheme 15) similar but lower activities were observed.

Table 4. Ethylene polymerization activity depending from the steric bulk of the Ap ligand.

\begin{tabular}{|c|c|c|c|c|}
\hline ligand & $\begin{array}{c}\mathbf{m}_{\text {Pol. }} \\
{[\mathrm{g}]}\end{array}$ & $\begin{array}{c}\text { activity } \\
{\left[\mathrm{kg}_{\mathrm{PE}} \mathrm{mol}_{\mathrm{Kat}}{ }^{-1} \mathrm{~h}^{-1} \mathrm{bar}^{-1}\right]}\end{array}$ & $\begin{array}{c}\mathbf{M}_{\mathbf{w}} \\
{\left[\mathrm{gmol}^{-1}\right]}\end{array}$ & $\mathbf{M}_{\mathbf{w}} / \mathbf{M}_{\mathbf{n}}$ \\
\hline Ap* & 13.4 & 1072 & $66500^{\mathrm{a}}$ & 3.2 \\
\hline $\mathrm{Ap}^{+}$ & 5.0 & 400 & $46100^{\mathrm{a}}\left(10800^{\mathrm{b}}\right)$ & $4.3(1.5)$ \\
\hline $\mathrm{Ap}^{-}$ & 5.4 & 432 & $263900^{\mathrm{a}}\left(16300^{\mathrm{b}}\right)$ & $28.8(2.4)$ \\
\hline
\end{tabular}

bimodal. ${ }^{\mathrm{b}} \mathrm{M}_{\mathrm{w}}$ of the main fraction ( $>90 \%$ )

It is very likely that the reduced steric bulk of Ap+ and Ap- does not lead selectively to mono Ap dialkyl complexes under the conditions used to generate the cations for polymerization studies. This hypothesis is supported by the observation that salt metathesis reactions with $[\mathrm{Ap}+\mathrm{K}]$ gave rise to complexes of the type $\left[\mathrm{Ap}+{ }_{2} \mathrm{Ln}(\mathrm{thf}) \mathrm{Cl}\right] .^{6}$

Temperature dependence studies of the organoyttrium catalyzed ethylene polymerization using the Ap* ligand revealed that the molecular weight increases with the reaction temperature. Furthermore, unusual small polydispersities down to $1.3(\mathrm{Mw} / \mathrm{Mn})$ were observed. It was concluded that a CCTP scenario between $\mathrm{Y}$ and TIBAO (triisobutylalumoxane) could be an explanation. ${ }^{42}$ A variety of experiments support this hypothesis. First, an increase of the Al to Y ration goes along with the formation of shorter polymer chains and all polymers contain an isopropyl endgroup steaming from TIBAO. 


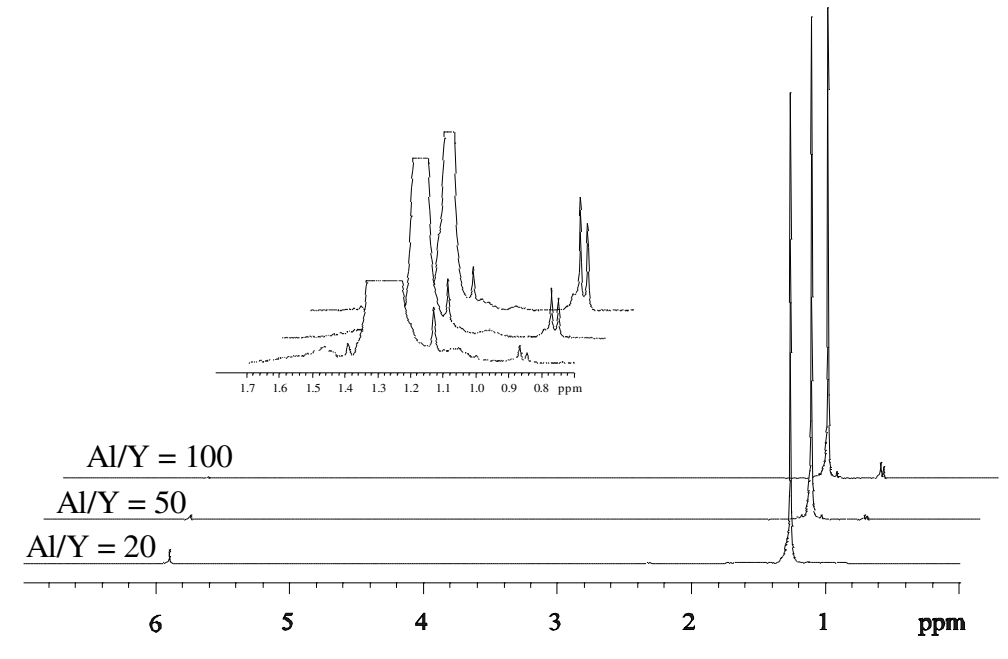

Figure 4. ${ }^{1} \mathrm{H}$ NMR spectra $\left(\mathrm{C}_{2} \underline{\mathrm{D}}_{2} \underline{\mathrm{Cl}}_{4}, 120^{\circ} \mathrm{C}\right)$ of PE . The inset shows the signal of the methyl groups of the isopropyl endgroup.

Secondly, a time depending growth of the polymer chain was observed. Polymer samples taken from one run $\left(80{ }^{\circ} \mathrm{C}\right.$ and 5 bar) were indicative of a increase of the molecular weight with the polymerization time (Figure 5).

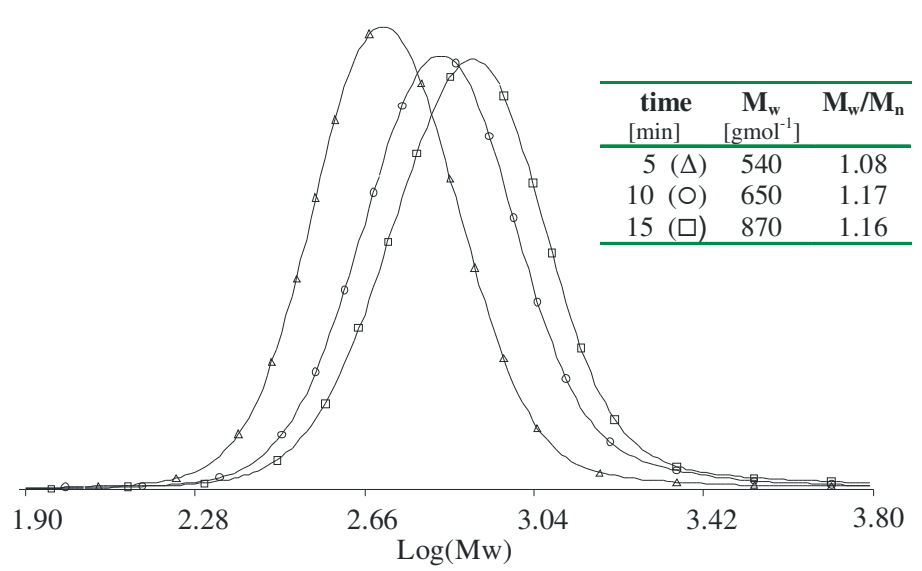

Figure 5. Time depended increase of the molecular weight of the polymers as determined by Deleted: nce SEC.

Thirdly, if chain transfer is fast in relation to chain growing very narrowly distributed polymers should be observed. Optimization of the reaction conditions in this regard led to the 
synthesis of PE with a polydispersity $\mathrm{Mw} / \mathrm{Mn}<1.1$ up to a molecular weight of $4000 \mathrm{~g} / \mathrm{mol}$

(Table 5).

Table 5. Optimization of the reaction conditions towards low polydispersity using the Ap*Y based catalyst system.

\begin{tabular}{|c|c|c|c|c|}
\hline $\begin{array}{c}\mathbf{A l} / \mathbf{Y} \\
{[\mathrm{mol} / \mathrm{mol}]}\end{array}$ & $\begin{array}{c}\mathbf{m}_{\text {pol. }} \\
{[\mathrm{g}]}\end{array}$ & $\begin{array}{c}\text { activity } \\
{\left[\mathrm{kg}_{\mathrm{PE}} \mathrm{mol}_{\mathrm{cat}}^{-1} \mathrm{~h}^{-1} \mathrm{bar}^{-1}\right]}\end{array}$ & $\begin{array}{c}\mathbf{M}_{\mathbf{w}} \\
{\left[\mathrm{gmol}^{-1}\right]}\end{array}$ & $\mathbf{M}_{\mathbf{w}} / \mathbf{M}_{\mathbf{n}}$ \\
\hline 0 & 0 & 0 & n.d. & n.d. \\
\hline 50 & 4.7 & 376 & 3940 & 1.09 \\
\hline 100 & 2.1 & 168 & 1460 & 1.05 \\
\hline $20^{\mathrm{a}}$ & 10.1 & 808 & 15600 & 1.4 \\
\hline
\end{tabular}

Higher molecular weights can not be obtained with a polydispersity of around 1.1 because polymers start to precipitate during polymerization and chain transfer is disturbed. Temporarily a bimodal distribution is observed (polymer in solution and polymer that is precipitated). After all polymer is precipitated a monomodal distribution is observed again which is slightly broader but sill indicative of a controlled process (last run Table 5).

Since synthesis of the trisalkyl precursors (from which the Ap dialkyls and the organo cations that undergo CCTP are generated) is challenging, especially for the early lanthanoids, better accessible precursors were searched for. A series of aminopyridinate stabilized rare earth amide complexes were synthesized and characterized. The bulky aminopyridines Ap*-H and $\mathrm{Ap}^{-}-\mathrm{H}$ were introduced via amine elimination reaction with $\left[\mathrm{Ln}(\operatorname{thf})_{2}\left\{\mathrm{~N}\left(\mathrm{SiHMe}_{2}\right)_{2}\right\}_{3}\right](\mathrm{Ln}=\mathrm{Y}$, La) to obtain the corresponding mono aminopyridinates. Unfortunately, these complexes are not able to undergo CCTP with ethylene in the presence of aluminum alkyls as the corresponding dialkyl complexes do. Investigations of the reactions of the rare earth aminopyridinate complexes with triethylaluminum or diisobutylaluminumhydride reveal a fast transfer of the aminopyridinato ligand to aluminum. The products of this transfer reaction are aminopyridinate stabilized aluminum dialkyls. ${ }^{43}$ 


\section{Variation of the Aluminum Alkyl and of the Supporting Ligand and Synthesis of Functionalized PE}

High control in ethylene polymerization was observed for the Ap*Y catalyst system in combination with TIBAO. ${ }^{42}$ The question arose: are other alumoxanes or aluminum alkyls able to promote CCTP as well?

Table 6. CCTP with the Ap* Y organo cation catalyst_- influence of the aluminum alkyl.

\begin{tabular}{|c|c|c|c|c|c|}
\hline$\underline{\mathrm{Al} \text {-alkyl }}$ & $\frac{\underline{\mathrm{Al} / \mathbf{Y}}}{[\mathrm{mol} / \mathrm{mol}]}$ & $\frac{\underline{\mathbf{m}}_{\text {pol. }}}{[\mathrm{g}]}$ & 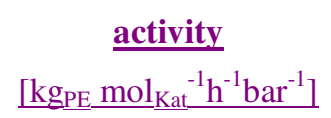 & $\begin{array}{c}\underline{\mathbf{M}}_{\underline{\mathbf{w}}} \\
{\left[\mathrm{gmol}^{-1}\right]}\end{array}$ & $\underline{\mathbf{M}}_{\underline{w}} / \underline{M}_{\underline{r}}$ \\
\hline TOA & $\underline{100}$ & $\underline{0.5}$ & $\underline{40}$ & n.d. & n.d. \\
\hline$\underline{\text { TIBA }}$ & $\underline{100}$ & $\underline{0.9}$ & 80 & $\underline{\text { n.d. }}$ & $\underline{\text { n.d. }}$ \\
\hline${\underline{\text { TIBA }^{\mathrm{a}}}}$ & $\underline{100}$ & $\underline{4.3}$ & 129 & $\underline{2660}$ & $\underline{1.2}$ \\
\hline$\underline{\text { TOAO }}$ & $\underline{100}$ & 1.9 & $\underline{152}$ & $\underline{2580}$ & $\underline{1.1}$ \\
\hline$\underline{\text { TIBAO }}$ & $\underline{100}$ & $\underline{2.1}$ & $\underline{168}$ & $\underline{1460}$ & $\underline{1.05}$ \\
\hline$\underline{\text { TPPAO }}$ & $\underline{50}$ & 1.9 & $\underline{152}$ & $\underline{2770}$ & $\underline{1.2}$ \\
\hline
\end{tabular}

As shown in Table 6 the organoyttrium cation catalyzed chain growing on aluminum is not limited to TIBAO themselves, but can be carried out with a variety of aluminum alkyls. However, the use of partially hydrolyzed Al-alkyls seems to have a strong beneficial effect on the ethylene polymerization activity. This behaviour could be explained by a stronger coordination of the aluminum trialkyls at the organoyttrium cation compared to the less electron rich alumoxanes. Consequently, the equilibrium between the CGS and the CTS is shifted towards the CTS. This goes along with a lower concentration of CGS and with a lower overall productivity. For the synthesis of well defined Al-terminated PE the use of simple aluminum alkyls is of advantage since they are better defined and the hydrolysis step can be waived. As shown in Scheme 1 a variety of ligands are related to Ap ligands and may also undergo CCTP. A sterically demanding amidine and guanidine, Am*-H and $\mathrm{Gu}^{*}-\mathrm{H}$, respectively (Scheme 16), were investigated in this regard. ${ }^{44}$ 


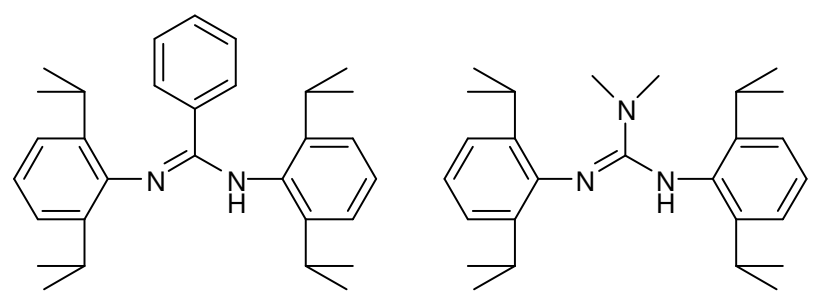

Scheme 16. Structure of Am*-H (right) and Gu*-H (left).

Selected polymerization results are shown in Table 7. They are indicative of CCTP in all cases. The $\mathrm{Am}^{*}$ based catalyst system is the most productive one in the presence of $\mathrm{Al}$ alkyls like triisobutylaluminum (= TIBA). This catalyst system is also very productive in combination with other aluminum alkyls like triethylaluminum.

Table 7. Ethylene polymerization a comparison of a $\mathrm{Y}$ aminopyridinate, a amidinate and a guanidinate.

\begin{tabular}{|c|c|c|c|c|}
\hline precatalyst & $\begin{array}{c}\mathrm{m}_{\text {Pol. }} \\
{[\mathrm{g}]}\end{array}$ & $\begin{array}{c}\text { activity } \\
{\left[\mathrm{kg}_{\mathrm{PE}} \mathrm{mol}_{\mathrm{Kat}}{ }^{-1} \mathrm{~h}^{-1} \mathrm{bar}^{-1}\right]}\end{array}$ & $\begin{array}{c}\mathrm{M}_{\mathrm{w}} \\
{[\mathrm{g} / \mathrm{mol}]}\end{array}$ & $\mathrm{M}_{\mathrm{w}} / \mathrm{M}_{\mathrm{n}}$ \\
\hline$[\mathrm{Ap} * \mathrm{Y}(\mathrm{thf}) \mathrm{R}]^{\mathrm{b}}$ & 0.9 & 80 & 1200 & 1.3 \\
\hline$[\mathrm{Am} * \mathrm{Y}(\mathrm{thf}) \mathrm{R}]^{\mathrm{b}}$ & 12.0 & 960 & 4200 & 1.2 \\
\hline$[\mathrm{Am} * \mathrm{Y}(\mathrm{thf}) \mathrm{R}]^{\mathrm{c}}$ & 6.5 & 520 & 1550 & 1.1 \\
\hline$[\mathrm{Gu} * \mathrm{Y}(\mathrm{thf}) \mathrm{R}]^{\mathrm{b}}$ & 3.0 & 240 & 2160 & 1.1 \\
\hline$[\mathrm{Gu} * \mathrm{Y}(\mathrm{thf}) \mathrm{R}]^{\mathrm{c}}$ & 1.2 & 96 & 1460 & 1.07 \\
\hline
\end{tabular}

Al terminated PE can undergo an oxidation reaction with $\mathrm{O}_{2}$ which leads to alkoxides that can be hydrolysed to form alcohols. ${ }^{45}$ These alcohols can be converted into a variety of functionalized PE materials as shown in Scheme $17 .^{44,46}$ 
Scheme 17. Modifications of OH-terminated PE.

The N-heterocyclic carbene precursor (Scheme 17, right bottom) is soluble only at temperatures above $90{ }^{\circ} \mathrm{C}$ and could be the basis of a recyclable ligand or catalyst complex. Cooling down to room temperature should allow precipitating the ligand/catalyst and reusing them.

\section{Isoprene Polymerization Mediated by Rare Earth Aminopyridinates}

Isoprene polymerization catalyzed by organolanthanoid cations has gained a lot of attention after the initial reports were published by two groups simultaneously ${ }^{47}$ Rare earth complexes of the type $\left[(\mathrm{L}) \mathrm{LnR}_{2}(\mathrm{D})\right]\left(\mathrm{R}=\mathrm{CH}_{2} \mathrm{SiMe}_{3}, \mathrm{AlMe}_{4}, o-\mathrm{CH}_{2} \mathrm{C}_{6} \mathrm{H}_{4} \mathrm{NMe}_{2}, \mu^{3}-\mathrm{C}_{3} \mathrm{H}_{5}, \mathrm{D}=\right.$ thf) where $\mathrm{L}$ is a cyclopentadienyl ${ }^{48}$ or an anionic $\mathrm{N}$-ligand, ${ }^{49,50}$ are known to mediate isoprene polymerization. ${ }^{51}\left[\left\{\mathrm{Me}_{2} \mathrm{Si}\left(\mathrm{C}_{5} \mathrm{Me}_{4}\right)-(\mathrm{PHCy})\right\} \mathrm{YCH}_{2} \mathrm{SiMe}_{3}\right]_{2} \quad\left(\mathrm{Cy}=\right.$ cyclohexyl $^{47 \mathrm{~b}}$ or $\left[\left(\mathrm{PhC}\left(\mathrm{NC}_{6} \mathrm{H}_{4} i \mathrm{Pr}_{2}-2,6\right)_{2}\right) \mathrm{Y}\left(o-\mathrm{CH}_{2} \mathrm{C}_{6} \mathrm{H}_{4} \mathrm{NMe}_{2}\right)_{2}\right]^{50}$ were shown, in the combination with $\left[\mathrm{Ph}_{3} \mathrm{C}\right]\left[\mathrm{B}\left(\mathrm{C}_{6} \mathrm{~F}_{5}\right)_{4}\right]$, to polymerize with very high regio- and stereoselectivities (3,4-selectivity: $>99 \%, \mathrm{mmmm}>99 \%$ ). In addition, it was observed, that the amidinate complex switches the stereoselectivity drastically from 3,4-isospecific to cis-1,4-selective by addition of $\mathrm{AlMe}_{3}$. Furthermore, half-sandwich complexes of the type $\left[\left(\mathrm{C}_{5} \mathrm{Me}_{5}\right) \mathrm{Ln}\left(\mathrm{AlMe}_{4}\right)_{2}\right](\mathrm{Ln}=\mathrm{Y}, \mathrm{La}, \mathrm{Nd})$, are (after activation) highly active catalysts for the living trans-1,4-selective (up to 99.5\%) polymerization of isoprene. ${ }^{48 \mathrm{~b}}$ Although 3,4-polyisoprene is used as an important component of high-performance rubber for example in tires, ${ }^{52}$ the number of 3,4-selective catalyst systems is smaller in contrast to systems which yield high cis-1,4-polyisoprene (natural rubber). ${ }^{48 \mathrm{~d}, 49 e, 50,53,54}$ 
In analogy to the synthesis of organoyttrium cations (Scheme 14) proceeds the synthesis of organoscandium cations. Ap ligand stabilized dialkyls are accessible in high yield from alkyl and benzyl precursors (Scheme 18).

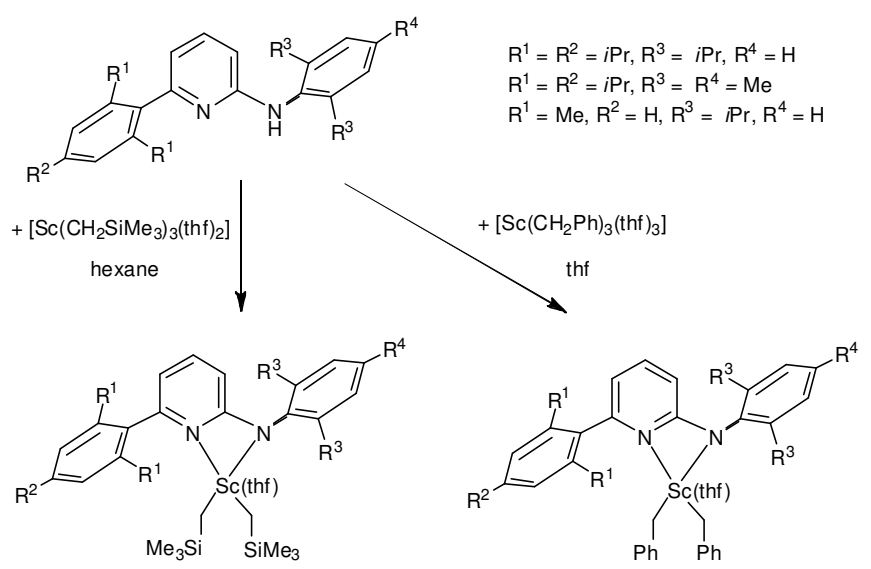

Scheme 18. Synthesis of scandium aminopyridinates.

The dialkyl and dibenzyl complexes shown in Scheme 18 can be activated with borates like $\left[\mathrm{Ph}_{3} \mathrm{C}\right]\left[\mathrm{B}\left(\mathrm{C}_{6} \mathrm{~F}_{5}\right)_{4}\right]$ and $\left[\mathrm{C}_{6} \mathrm{H}_{5} \mathrm{NHMe}_{2}\right]\left[\mathrm{B}\left(\mathrm{C}_{6} \mathrm{H}_{5}\right)_{4}\right]$ to form organo cations (Scheme 19).

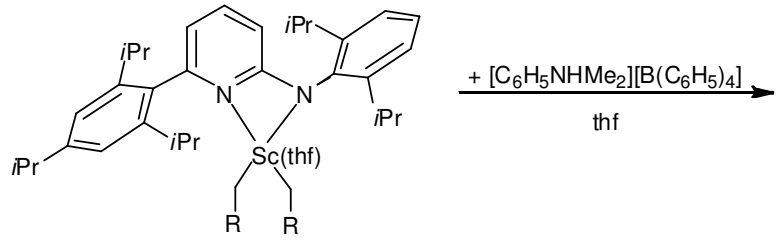

Scheme 19. Synthesis of organo scandium cations.

Scandium cations generated by addition of $\left[\mathrm{Ph}_{3} \mathrm{C}\right]\left[\mathrm{B}\left(\mathrm{C}_{6} \mathrm{~F}_{5}\right)_{4}\right]$ are active and selective catalysts for the controlled 3,4-selective polymerization of isoprene. The presence of alkylaluminum compounds leads to drastical changes in the microstructure of the polymers. The highest stereo- and regioselectivity was observed for the catalyst/activator system [Ap* $\left.\mathrm{Sc}(\mathrm{thf}) \mathrm{Bn}_{2}\right] /$ $\left[\mathrm{Ph}_{3} \mathrm{C}\right]\left[\mathrm{B}\left(\mathrm{C}_{6} \mathrm{~F}_{5}\right)_{4}\right]\left(3,4\right.$-content $95 \%, \mathrm{~mm}=100 \%, \mathrm{mmmm}=35 \%, M_{\mathrm{w}} / M_{\mathrm{n}}=1.68, \mathrm{Bn}=$ benzyl), whereas the system $\left[\mathrm{Ap} * \mathrm{Sc}(\mathrm{thf})\left(\mathrm{CH}_{2} \mathrm{SiMe}_{3}\right)_{2}\right] /\left[\mathrm{C}_{6} \mathrm{H}_{5} \mathrm{NH}\left(\mathrm{CH}_{3}\right)_{2}\right]\left[\mathrm{B}\left(\mathrm{C}_{6} \mathrm{~F}_{5}\right)_{4}\right]$ shows the narrowest molecular weight distribution $\left(3,4\right.$-content $\left.93 \%, M_{\mathrm{w}} / M_{\mathrm{n}}=1.26\right)$. The ternary systems $\quad\left[\mathrm{Ap} * \mathrm{Sc}(\mathrm{thf})\left(\mathrm{N}\left\{\mathrm{SiHMe}_{2}\right\}_{2}\right] / \mathrm{AlR}_{3} /\left[\mathrm{C}_{6} \mathrm{H}_{5} \mathrm{NH}\left(\mathrm{CH}_{3}\right)_{2}\right]\left[\mathrm{B}\left(\mathrm{C}_{6} \mathrm{~F}_{5}\right)_{4}\right] \quad\right.$ and $\left[\mathrm{Sc}\left\{\mathrm{N}\left(\mathrm{SiHMe}_{2}\right)_{2}\right\}_{3}(\mathrm{thf})\right] / \mathrm{AlR}_{3} /\left[\mathrm{C}_{6} \mathrm{H}_{5} \mathrm{NH}\left(\mathrm{CH}_{3}\right)_{2}\right]\left[\mathrm{B}\left(\mathrm{C}_{6} \mathrm{~F}_{5}\right)_{4}\right](\mathrm{R}=\mathrm{Me}, i \mathrm{Bu})$ polymerize isoprene 
cis-1,4-selective. The use of binary catalyst systems based on larger rare earth metals leads to a degrease of the 3,4 content and an increase of an cis-1,4 content. ${ }^{55}$

\section{Conclusions}

Rare earth atoms stabilized by bulky aminopyridinato ligands are a versatile class of polymerization catalysts. The tailoring of the steric bulk of the Ap ligand in combination with the choice of 17 similar (in terms of the general reactivity) but distinct differently (in terms of the ionic radii) rare earth atoms allows a fine tuning of the catalyst activity and selectivity. Some preliminary proof of principle studies have been carried out. The potential of this (polymerization) catalyst class is large but largely unexplored.

\section{Acknowledgement}

We thank the DFG for financial support within the SPP 1166 "Lanthanoid-specific functionalities in molecules and materials". I also like to thank all the talented coworkers that have worked in these projects for their inspiring input.

${ }^{1}$ For review articles on aminopyridinato ligands see: a) R. Kempe, H. Noss, T. Irrgang, $J$. Organomet. Chem. 2002, 647, 12-20; b) R. Kempe, Eur. J. Inorg. Chem. 2003, 791-803.

${ }^{2}$ For discussion of the binding modes see: S. Deeken, G. Motz, R. Kempe, Z. Anorg. Allg. Chem. 2007, 633, 320-325.

${ }^{3}$ For the general applicability of the ligands see: G. Glatz, S. Demeshko, G. Motz, R. Kempe, Eur. J. Inorg. Chem. 2009, 1385-1392.

${ }^{4}$ The term rare earth (metal or atom) includes the group 3 elements Sc, Y und La as well as the lanthanoids themselves the elements from $\mathrm{Ce}$ till $\mathrm{Lu}$.

${ }^{5}$ N. M. Scott, T. Schareina, O. Tok, R. Kempe, Eur. J. Inorg. Chem. 2004, 3297-3304.

${ }^{6}$ N. M. Scott, R. Kempe, Eur. J. Inorg. Chem. 2005, 1319-1324.

${ }^{7}$ W. P. Kretschmer, A. Meetsma, B. Hessen, N. M. Scott, S. Qayyum, R. Kempe, Z. Anorg. Allg. Chem. 2006, 632, 1936-1938.

${ }^{8}$ For selected reviews please see: a) A. E. Shilov, G. B. Shul'pin, Chem. Rev. 1997, 97, 28792932. b) C. Jia, T. Kitamura, Y. Fujiwara, Acc. Chem. Res. 2001, 34, 633-639. c) K. Godula, D. Sames, Science 2006, 312, 67-72; d) F. Kakiuchi, T. Kochi, Synthesis 2008, 19, 30133039.

9 a) M. Brookhart, M. L. H. Green, J. Organomet. Chem. 1983, 250, 395- 408; b) W. J. Evans, L. A. Hughes, T. P. Hanusa, J. Am. Chem. Soc. 1984, 106, 4270-4272; c) W. J. Evans, L. A. 
Hughes, T. P. Hanusa, Organometallics 1986, 5, 1285-1291; d) P. B .Hitchcock, J. A. K. Howard, M. F. Lappert, S. Prashar, J. Organomet. Chem. 1992, 437, 177-189; e) S. Qayyum, K. Haberland, C. M. Forsyth, P. C. Junk, G. B. Deacon, R. Kempe, Eur. J. Inorg. Chem. 2008, 557-562.

10 a) P. L. Watson, J. Chem. Soc., Chem. Commun. 1983, 276-277; b) P. L .Watson, G. B. Parshall, Acc. Chem. Res. 1985, 18, 51-56; c) P. L. Watson, J. Am. Chem. Soc. 1983, 105, 6491-6493; d) N. Barros, O. Eisenstein, L. Maron, Dalton Trans. 2006, 3052-3057.

11 a) K. H. den Haan, J. H. Teuben, J. Chem. Soc., Chem. Commun. 1986, 682-683; b) M. E. Thompson, S. M. Baxter, A. R. Bulls, B. J. Burger, M. C. Nolan, B. D. Santarsiero, W. P. Schaefer, J. E. Bercaw, J. Am. Chem. Soc. 1987, 109, 203-219; c) K. H. den Haan, Y. Wiestra, J. H. Teuben, Organometallics 1987, 6, 2053-2060; d) W. J. Evans, T. A. Ulibarri, J. W. Ziller, Organometallics 1991, 10, 134-142; e) M. Booij, A. Meetsma, J. H. Teuben, Organometallics 1991, 10, 3246-3552; f) M. Booij, B. J. Deelman, R. D. Duchateau, J. Postma, A. Meetsma, J. H. Teuben, Organometallics 1993, 12, 3531-3540; g) W. J. Evans, J. M. Perotti, J. W. Ziller, Inorg. Chem. 2005, 44, 5820-5825; h) W. J. Evans, J. M. Perotti, J. W. Ziller, J. Am. Chem. Soc. 2005, 127, 3894-3909; i) W. J. Evans, T. M. Champagne, J. W. Ziller, J. Am. Chem. Soc. 2006, 128, 14270-14271.

12 For selected examples please see: a) M. D. Fryzuk, T. S. Haddad, S. J. Rettig, Organometallics 1991, 10, 2026-2036; b) Y. Mu, W. E Piers, D. C. Mac Quarrie, M. J. Zaworotko, V. G. Young, Organometallics 1996, 15, 2720-2726; c) R. Duchateau, T. Tuinstra, E. A. C. Brussee, A. Meetsma, P. T. van Duijnen, J. H. Teuben, Organometallics 1997, 16, 3511-3522; d) D. J. H. Emslie, W. E. Piers, M. Parvez, R. McDonald, Organometallics 2002, 21, 4226-4240; e) D. J. H. Emslie, W. E. Piers, M. Parvez, Dalton Trans. 2003, 2615-2620; f) L. K. Knight, W. E. Piers, P. Fleurat-Lessard, P. Masood, R. McDonald, Organometallics 2004, 23, 2087-2094; g) L. K. Knight, W. E. Piers, R. McDonald, Organometallics, 2006, 25, 3289-3292; h) M. Zimmermann, F. Estler, E. Herdtweck, W. K. Törnroos, R. Anwander, Organometallics 2007, 26, 6029-6041.

13 G. G. Skvortsov, G. K. Fukin, A. A. Trifonov, A. Noor, C. Döring, R. Kempe, Organometallics 2007, 26, 5770-5773.

${ }^{14}$ S. Qayyum, G. G. Skvortsov, G. K. Fukin, A. A. Trifonov, W. P. Kretschmer, C. Döring, R. Kempe, Eur. J. Inorg. Chem. 2010, 248-257.

${ }^{15}$ D. M. Lyubov, C. Döring, G. K. Fukin, A. V. Cherkasov, A. V. Shavyrin, R. Kempe, A. A. Trifonov, Organometallics 2008, 27, 2905-2907. 
${ }^{16}$ W. P. Kretschmer, A. Meetsma, B. Hessen, T. Schmalz, S. Qayyum, R. Kempe, Chem. Eur. J. 2006, 12, 8969-8978.

${ }^{17}$ Selected reviews on rare earth metal hydride complexes: a) M. Masayoshi, Z. Hou, Nature Chem. 2010, 2, 257-268; b) M. Konkol, J. Okuda, Coord. Chem. Rev. 2008, 252, 1577-1591; c) A. A. Trifonov, Rus. Chem. Rev. 2007, 76, 1051-1072; d) Z. Hou, M. Nishiura, T. Shima, Eur. J. Inorg. Chem. 2007, 2535-2545; e) Z. Hou, Bull. Chem. Soc. Jpn. 2003, 76, 22532266; f) J. Okuda, Dalton Trans. 2003, 2367-2378; g) S. Arndt, J. Okuda, Chem. Rev. 2002, 102, 1953-1976; h) G. A. Molander, J. A. C. Romero, Chem. Rev. 2002, 102, 2161-2186; i) Z. Hou, Y. Wakatsuki, Coord. Chem. Rev. 2002, 231, 1-22; j) Z. Hou, Y. Wakatsuki, in Science of Synthesis (Eds.: T. Imamoto, R. Noyori), Thieme, Stuttgart, 2002, vol. 2, p. 849942; k) A. J. Hoskin, D. W. Stephan, Coord. Chem. Rev. 2002, 233-234, 107-129; 1) M. Ephritikhine, Chem. Rev. 1997, 97, 2193-2242; m) H. Schumann, J. A. Meese-Marktscheffel, L. Esser, Chem. Rev. 1995, 95, 865-986; n) F. T. Edelmann, in Comprehensive Organometallic Chemistry II (Eds.: E. W. Abel, F. G. A. Stone, G. Wilkinson, M. F. Lappert), Pergamon, Oxford, 1995, vol. 4, p. 11-212; o) C. J. Schaverien, Adv. Organomet. Chem. 1994, 36, 283-362.

18 a) W. J. Evans, J. H. Meadows, A. L. Wayda, J. Am. Chem. Soc. 1982, 104, 2015- 2017; b) W. J. Evans, J. H. Meadows, T. P. Hanusa, J. Am. Chem. Soc. 1984, 106, 4454-4460. c) W. J. Evans, M. S. Sollberger, S. I. Khan, R. Bau, J. Am. Chem. Soc. 1988, 110, 439-446.

19 a) Dissertation K. C. Hultzsch Johannes Gutenberg-Universität Mainz 1999; b) K. C. Hultzsch, T. P. Spaniol, J. Okuda, Angew. Chemie 1999, 111, 163-165; Angew. Chem. Int. Ed. 1999, 38, 227-230.

${ }^{20}$ Z. Hou, Y. Zhang,; O. Tardif, Y. Wakatsuki, J. Am. Chem. Soc. 2001, 123, 9216-9217.

${ }^{21}$ M. Yousufuddin, M. J. Gutmann, J. Baldamus, O. Tardif, Z. Hou, S. A. Mason, G. J. McIntyre, R. Bau, J. Am. Chem. Soc. 2008, 130, 3888-3891.

${ }^{22}$ S. Qayyum, A. Noor, G. Glatz, R. Kempe, Z. Anorg. Allg. Chem. 2009, 635, 2455-2458.

${ }^{23}$ For reviews see: a) G. B. Deacon, C. M. Forsyth, in Inorganic Chemistry Highlights, ed. G. Meyer, D. Naumann and L. Wesemann, Wiley - VCH, Weinheim, 2002, ch 7, p139-153; b) K. Müller-Buschbaum, Z. Anorg. Allg. Chem. 2005, 631, 811-828.

${ }^{24}$ For selected examples published prior to our article see: a) G. B. Deacon, C. M. Forsyth, P. C. Junk, B. W. Skelton, A. H. White, Chem. Eur. J. 1999, 5, 1452-1459; b) G. B. Deacon, T. Feng, C. M. Forsyth, A. Gitlits, D. C. R. Hockless, Q. Shen, B. W. Skelton, A. H. White, J. Chem. Soc., Dalton Trans. 2000, 961-966; c) G. B. Deacon, A. Gitlits, P. W. Roesky, M. K. 
Burgstein, K.C. Lim, B.W. Skelton, A.H. White, Chem. Eur. J. 2001, 7, 127-128; d) G.B. Deacon, C.M. Forsyth, A. Gitlits, R. Harika, P.C. Junk, B.W. Skelton, A.H. White, Angew. Chem. 2002, 114, 1383-1385; Angew. Chem., Int. Ed. Engl. 2002, 41, 3249-3251; e) K. Müller-Buschbaum, Z. Anorg. Allg. Chem. 2003, 629, 2127-2132; f) G.B. Deacon, C.M. Forsyth, A. Gitlits, B.W. Skelton, A.H. White, Dalton Trans. 2004, 1239-1247; g) K. MüllerBuschbaum, C. Quitmann, Inorg. Chem. 2006, 45, 2678-2687; h) G.B. Deacon, C.M. Forsyth, P.C. Junk, S.G. Leary, New. J. Chem. 2006, 30, 592-596; i) C.C. Quitmann, V. Bezugly, F.R. Wagner, K. Müller-Buschbaum, Z. Anorg. Allg. Chem. 2006, 632, 1173-1186;

${ }^{25}$ For examples see: a) J. Hitzbleck, A.T. O’Brien, C.M. Forsyth, G.B. Deacon, K. RuhlandtSenge, Chem. Eur. J. 2004, 10, 3315-3323; b) J. Hitzbleck, G.B. Deacon, K. Ruhlandt-Senge, Angew. Chem. 2004, 116, 5330-5332; Angew. Chem., Int. Ed. Engl. 2004, 43, 5218-5230.

${ }^{26}$ S. Qayyum, K. Haberland, C. M. Forsyth, P. C. Junk, G. B. Deacon, R. Kempe, Eur. J. Inorg. Chem. 2008, 557-562.

27 a) K. M. Stridsberg, M. Ryner, A.-C. Albertsson, Adv. Polym. Sci. 2002, 157, 42-65; b) A. C. Albertsson, I. K. Varma, Adv. Polym. Sci. 2002, 157, 2-41.

${ }^{28}$ a) Z. Hou, Y. Wakatsuki, Coord. Chem. Rev. 2002, 231, 1-22; b) S. Agarwal, C. Mast, K. Dehnicke, A. Greiner, Macromol. Rapid Commun. 2000, 21, 195-212; c) H. Yasuda, J. Organometallic Chem. 2002, 647, 128-138.

29 a) M. Okada, Prog. Polym. Sci. 2002, 27, 87-133; b) M. Vert; Biomacromolecules 2005, 6, 538-546; c) A.-C. Albertsson, I. K. Varma, Biomacromolecules 2003, 4, 1466-1486; d) T. Freier, Adv. Polym. Sci. 2006, 203, 1-61; e) M. S. Lindblad, Y. Liu, A.-C. Albertsson, E. Ranucci, S. Karlsson, Adv. Polym. Sci. 2002, 157, 141-160; f) S. Matsumura, Adv. Polym. Sci. 2006, 194, 95-132.

30 a) S. M. Cendrowski-Guillaume, G. Le Gland, M. Nierlich, M. Ephritikhine, Organometallics 2000, 19, 5654-5660; b) S. M. Cendrowski-Guillaume, M. Nierlich, M. Lance, M. Ephritikhine, Organometallics 1998, 17, 786-788.

31 a) S. M. Guillaume, M. Schappacher, A. Soum, Macromolecules 2003, 36, 54-60; b) I. Palard, A. Soum, S. M. Guillaume, Chem. Eur. J. 2004, 10, 4054-4062; c) I. Palard, A. Soum, S. M. Guillaume, Macromolecules 2005, 6888-6894; d) I. Palard, M. Schappacher, A. Soum, S. M. Guillaume, Polym. Int. 2006, 55, 1132-1137.

${ }^{32}$ H. Noss, M. Oberthür, C. Fischer, W. P. Kretschmer, R. Kempe, Eur. J. Inorg. Chem. 1999, 2283-2288. 
${ }^{33}$ S. M. Guillaume, M. Schappacher, N. M. Scott, R. Kempe, J. Polym. Sci. Part A: Polym. Chem. 2007, 45, 3611-3619.

${ }^{34}$ a) Y. Shen, Z. Shen, Y. Zhang, Q. Hang, J. Polym. Sci., Part A : Polym. Chem. 1997, 35, 1339-1352; b) Y. Shen, Y.; K. J. Zu, Z. Shen, K. Yao, J. Polym. Sci., Part A : Polym. Chem. 1996, 34, 1799-1805; c) Y. Shen, Z. Shen, J. Shen, Y. Zhang, K. Yao, Macromolecules 1996, 29, 3441-3446.

${ }^{35}$ a) S. Agarwal, M. Karl, K. Dehnicke, G. Seybert, W. Massa, A. Greiner, J. Appl. Polym. Sci. 1999, 73, 1669-1674; b) S. Agarwal, C. Mast, S. Anfang, M. Karl, K. Dehnicke, A. Greiner, Polym. Prepr. 1998, 39, 414-415; c) S. Agarwal, M. Karl, S. Anfang, K. Dehnicke, A. Greiner, Polym. Prepr. 1998, 39, 361-362; d) S. Agarwal, A. Greiner, J. Chem. Soc., Perkin Trans. 2002, 2033-2042.

${ }^{36}$ T. J. Woodman, M. Schormann, D. L. Hughes, M. Bochmann, Organometallics 2004, 23, 2972-2979.

${ }^{37}$ R. Kempe, Chem. Eur. J. 2007, 13, 2764-2773.

${ }^{38}$ a) E. G. Samsel, Ethyl Corporation, EP 0539876, 1993; b) E. G. Samsel, Ethyl Corporation, EP 0574854, 1993.

39 a) J.-F. Pelletier, A. Mortreux, X. Olonde, K. Bujadoux, Angew. Chem. 1996, 108, 19801982; Angew. Chem. Int. Ed. 1996, 35, 1854-1856; b) J. F. Pelletier, K. Bujadoux, X. Olonde, E. Adisson, A. Mortreux, T. Chenal, US 5779942, 1998.

40 a) J. S. Rogers, G. C. Bazan, Chem. Commun. 2000, 1209-1210; b) G. C. Bazan, J. S. Rogers, C. C. Fang, Organometallics 2001, 20, 2059-2064; c) G. Mani, F. P. Gabbai, Angew. Chem. 2004, 116, 2313-2316; Angew. Chem. Int. Ed. 2004, 43, 2263-2266; d) G. Mani, F. P. Gabbai, J. Organomet. Chem. 2005, 690, 5145-5149; e) G. J. P. Britovsek, S. A. Cohen, V. C. Gibson, P. J. Maddox, M. van Meurs, Angew. Chem. 2002, 114, 507-509; Angew. Chem. Int. $E d .2002,41$, 489-491; f) G. J. P. Britovsek, S. A. Cohen, V. C. Gibson, M. van Meurs, J. Am. Chem. Soc. 2004, 126, 10701-10712; g) M. van Meurs, G. J. P. Britovsek, V. C. Gibson, S. A. Cohen, J. Am. Chem. Soc. 2005, 127, 9913-9923; h) J. Saito, Y. Tohi, N. Matsukawa, M. Mitani and T. Fujita, Macromolecules, 2005, 38, 4955-4957. i) T. Chenal, X. Olonde, J.-F. Pelletier, K. Bujadoux, M. Mortreux, Polymer 2007, 48, 1844-1856; j) W. Zhang, L. R. Sita, J. Am. Chem. Soc. 2008, 130, 442-443; k) W. Zhang, J. Wei, L. R. Sita, Macromolecules 2008, 41, 7829-7833; 1) J. Wei, W. Zhang and L. R. Sita, Angew. Chem. 2010, 122, 1-4, Angew. Chem. Int. Ed., 2010, 49, 14-18. 
${ }^{41}$ For selected reviews on cationic rare earth metal alkyls see: a) Z. Hou, Y. Luo, X. Li, J. Organomet. Chem. 2006, 691, 3114-3121; b) S. Arndt, J. Okuda, Adv. Synth. Catal. 2005, 347, 339-354; c) S. Arndt, J. Okuda, Chem. Rev. 2002, 102, 1953-1976; d) P. M. Zeimentz, S. Arndt, B. R. Elvidge, J. Okuda, Chem. Rev. 2006, 106, 2404-2433.

${ }^{42}$ W. P. Kretschmer, A. Meetsma, B. Hessen, T. Schmalz, S. Qayyum, R. Kempe, Chem. Eur. J. 2006, 12, 8969-8978.

${ }^{43}$ C. Doering, R. Kempe, Eur. J. Inorg. Chem. 2009, 412-418.

${ }^{44}$ W. P. Kretschmer, T. Bauer, B. Hessen, R. Kempe, Dalton Trans., 2010, 1 , accepted.

${ }^{45}$ This process is run on tonne scale in chemical industry for short chain $\mathrm{Al}(\mathrm{PE})_{3}$.

${ }^{46}$ R. Briquel, J. Mazzolini, T. Le Bris, O. Boyron, F. Boisson, F. Delolme, F. D'Agosto, C. Boisson and R. Spitz, Angew. Chem. 2008, 120, 9451-9453; Angew. Chem. Int. Ed. 2008, 47, 9311-9313.

${ }^{47}$ a) S. Arndt, K. Beckerle, P. M. Zeimentz, T. P. Spaniol, J. Okuda, Angew. Chem. 2005, 117, 7640-7644; Angew. Chem. Int. Ed. 2005, 44, 7473-7477; b) L. Zhang, Y. Luo, Z. Hou, J. Am. Chem. Soc. 2005, 127, 14562-14563.

48 a) E. Le Roux, F. Nief, F. Jaroschik, K. W. Törnroos, R. Anwander, Dalton Trans. 2007, 4866. b) M. Zimmermann, K. W. Törnroos, R. Anwander, Angew. Chem. 2008, 120, 787-790; Angew. Chem. Int. Ed. 2008, 47, 775-778; c) M. Zimmermann, K. W. Törnroos, H. Sitzmann, R. Anwander, Chem. Eur. J. 2008, 14, 7266-7277; d) B. Wang, D. Cui, K. Lv, Macromolecules 2008, 41, 1983-1988; e) N. Yu, M. Nishiura, X. Li, Z. Xi, Z. Hou, Chem. Asian J. 2008, 3, 1406-1414; f) H. Zhang, Y. Luo, Z. Hou, Macromolecules 2008, 41, 1064 1066; g) A.-S. Rodriguesa, E. Kirillova, B. Vuilleminb, A. Razavic, J.-F. Carpentier, Polymer 2008, 49, 2039-2045.

49 a) L. Zhang, T. Suzuki, Y. Luo, M. Nishiura, Z. Hou, Angew. Chem. 2007, 119, 1941-1945; Angew. Chem. Int. Ed. 2007, 46, 1909-1913; b) Y. Luo, M. Nishiura, Z. Hou, J. Organomet. Chem. 2007, 692, 536-544; c) Y. Yang, B. Liu, K. Lv, W. Gao, D. Cui, X. Chen, X. Jing, Organometallics 2007, 26, 4575-4584; d) Y. Yang, Q. Wang, D. Cui, J. Polym. Sci. Part A: Polym. Chem. 2008, 46, 5251-5262; e) S. Li, W. Miao, T. Tang, W. Dong, X. Zhang, D. Cui, Organometallics 2008, 27, 718-725; f) W. Gao, D. Cui, J. Am. Chem. Soc. 2008, 130, 49844991.

${ }^{50}$ L. Zhang, M. Nishiura, M. Yuki, Y. Luo, Z. Hou, Angew. Chem. 2008, 120, 2682-2685; Angew. Chem. Int. Ed. 2008, 47, 2642-2645. 
${ }^{51}$ For an example of a stoichiometric reaction of a yttrium alkyl complex with isoprene see: B. Liu, X. Liu, D. Cui, L. Liu, Organometallics 2009, 28, 1453-1460.

52 a) J. Wolpers, H. B. Fuchs, C. Herrmann, W. Hellermann, K. H. Nordsiek, Eur. Pat. Appl. EP 456902 A1, 1991; b) J. D. Massie, W. Hsu, A.F. Halasa, P. H. Sandstrom, US Pat. US 5356997, 1994; c) A. F. Halasa, W. Hsu, D. J. Zanzig, G. L. Allen, L. E. Austin, US Patent US 5627237 A, 1997.

${ }^{53}$ Selected reviews on isoprene polymerization: a) L. Porri, A. Giarrusso in Comprehensive Polymer Science, Vol. 4 (Eds.: G. C. Eastmond, A. Ledwith, S. Russo, P. Sigwalt), Pergamon, Oxford, 1989, pp. 74-79; b) R. Taube, G. Sylvester in Applied Homogeneous Catalysis with Organometallic Compounds, Vol. 2 (Eds.: B. Cornils, W. A. Herrmann), Wiley-VCH, Weinheim, 1996, pp. 285-315; c) L. Friebe, O. Nuyken, W. Obrecht, Adv. Polym. Sci. 2006, 204, 82-83; d) A. Fischbach, R. Anwander, Adv. Polym. Sci. 2006, 204, 155-191.

${ }^{54}$ For examples of 3,4-polymerization of isoprene please see: a) G. Natta, L. Porri, A. Carbonaro, Makromol. Chem. 1964, 77, 126-138; b) W. Gronski, N. Murayama, H. J. Cantow, T. Miyamoto, Polymer 1976, 17, 358-360. c) G. Ricci, M. Battistella, L. Porri, Macromolecules 2001, 34, 5766-5769; d) C. Bazzini, A. Giarrusso, L. Porri, Macromol. Rapid Commun. 2002, 23, 922-927; e) Y. Nakayama, Y. Baba, H. Yasuda, K. Kawakita, N. Ueyama, Macromolecules 2003, 36, 7953-7958. f) C. Bazzini, A. Giarrusso, L. Porri, B. Pirozzi, R. Napolitano, Polymer 2004, 45, 2871-2875; g) Z. Hou, Y. Luo, X. Li, J. Organomet. Chem. 2006, 691, 3114-3121.

${ }^{55}$ C. Doering, W. P. Kretschmer, R. Kempe, Eur. J. Inorg. Chem. 2010, in press. 


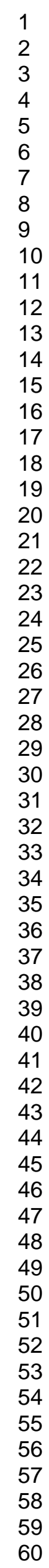

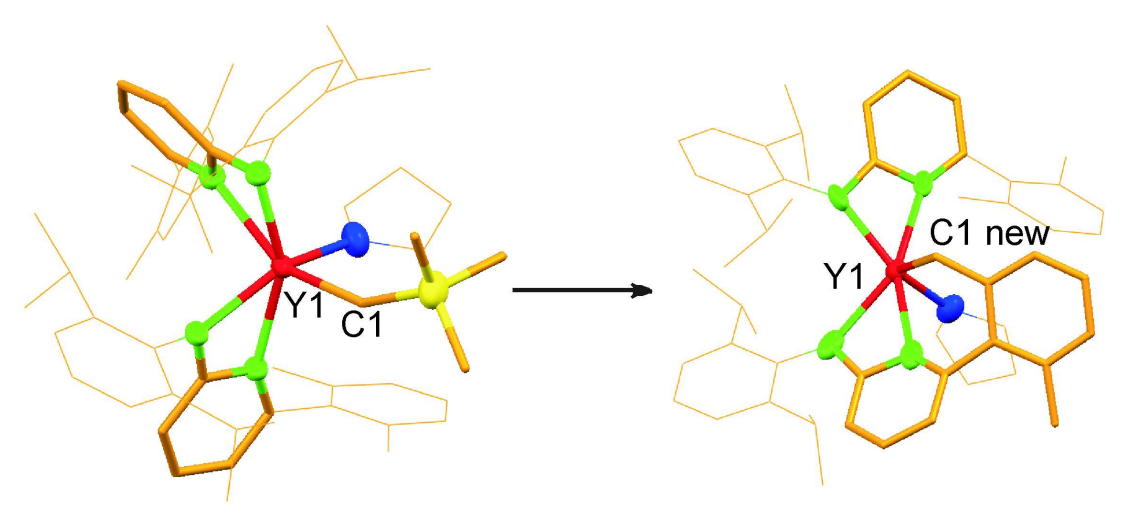

$\mathrm{C}-\mathrm{H}$ activation of one of the methyl groups of $\mathrm{Ap}+$ in $[\mathrm{Ap}+2 \mathrm{Y}(\mathrm{thf}) \mathrm{CH} 2 \mathrm{SiMe} 3]$. 
Molecular structure of $[(\mathrm{Ap} * \mathrm{Y}) 3(\mu 2-\mathrm{H}) 3(\mu 3-\mathrm{H}) 2(\mathrm{CH} 2 \mathrm{SiMe} 3)($ thf $) 2)]$. The iPr groups of the Ap* ligands are omitted. Selected bond lengths $[\AA]$ and angles $[0]: Y(1 A)-N(1 A) 2.323(2), Y(1 A)-N(2 A)$ 2.459(2), $Y(1 A)-Y(1 B) 3.4408(4), Y(1 A)-Y(1 C) 3.5158(4), Y(1 B)-N(1 B) 2.307(2), Y(1 B)-O(1 B)$ $2.3510(19), Y(1 B)-N(2 B) 2.477(2), Y(1 B)-Y(1 C) 3.5058(4), Y(1 C)-N(1 C) 2.331(2), Y(1 C)-C(33 C)$ 2.402(3), $Y(1 C)-N(2 C) 2.503(2), Y(1 B)-Y(1 A)-Y(1 C) 60.512(8), N(1 A)-Y(1 A)-N(2 A) \quad 56.70(8)$, $\mathrm{N}(1 \mathrm{~B})-\mathrm{Y}(1 \mathrm{~B})-\mathrm{N}(2 \mathrm{~B}) 56.64(7), \mathrm{N}(1 \mathrm{C})-\mathrm{Y}(1 \mathrm{C})-\mathrm{N}(2 \mathrm{C}) 56.40(7)$. $361 \times 270 \mathrm{~mm}(72 \times 72 \mathrm{DPI})$ 


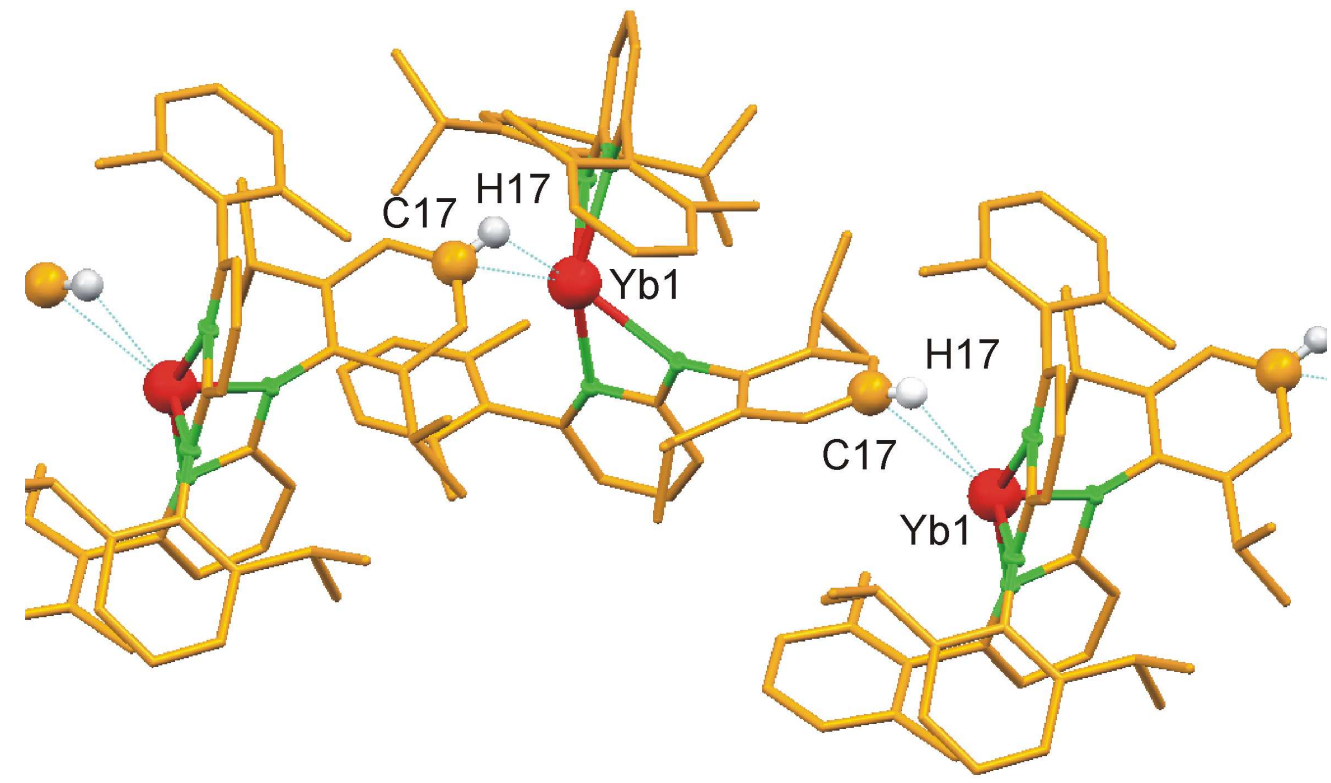

Solid state structure of $[A p+2 Y b]$ showing an intermolecular agostic interactions (Yb1...C17 2.981(2) $\AA$ and $\mathrm{Yb} 1$...H17 distances $2.56(3) \AA)$. 

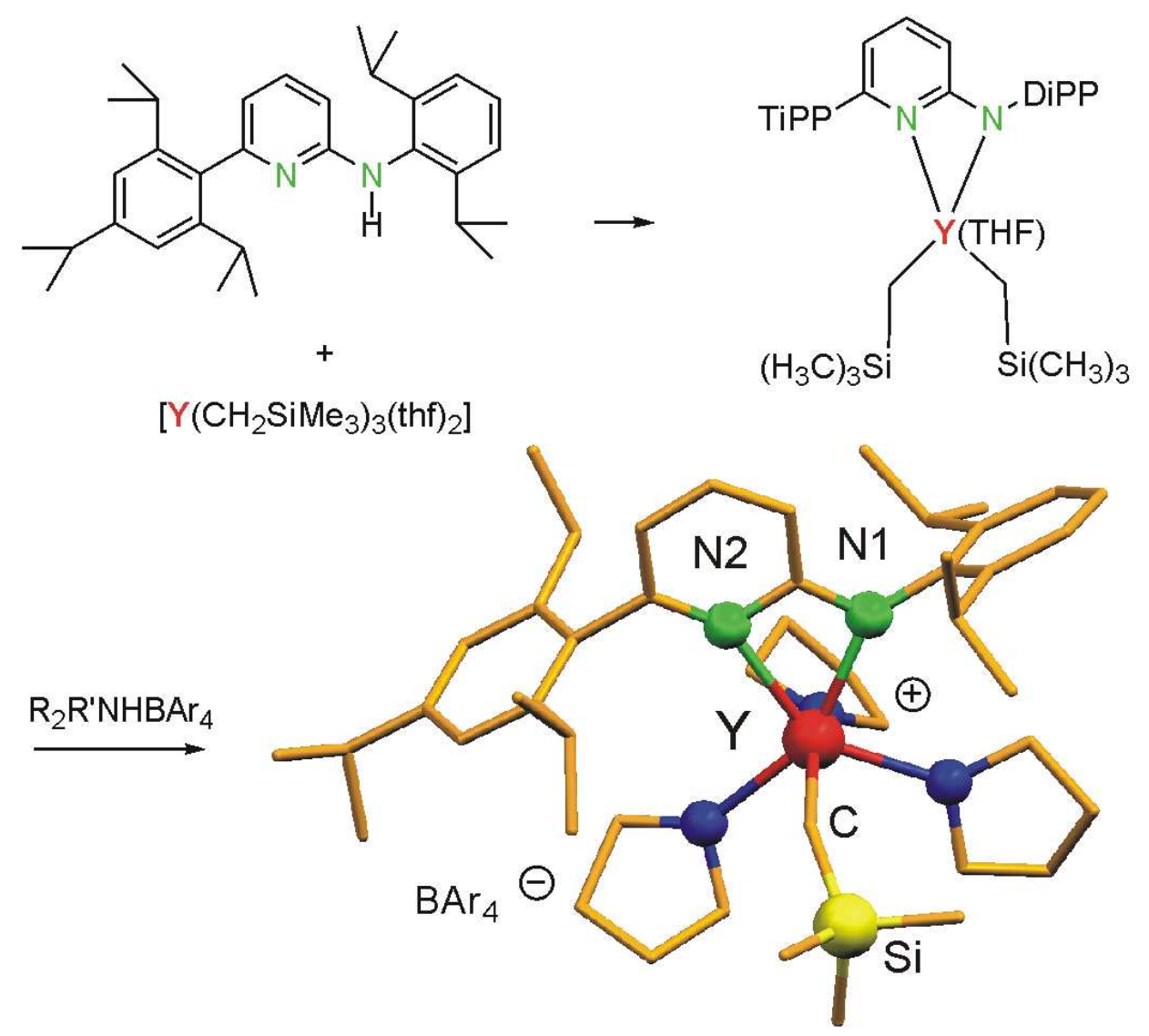

Synthesis and molecular structure of $\{[\mathrm{Ap} * Y($ thf $) 3 \mathrm{CH} 2 \mathrm{SiMe} 3]+[\mathrm{B}(\mathrm{C} 6 \mathrm{~F} 5) 4]-\}$. The anion is simplified. Two independent cations per asymmetric unit were found; selected bond parameters $\left[\AA{ }^{\circ}\right]$ averaged: Y-N1 2.302(3), Y-N2 2.421(3), Y-C 2.382(4), N1-Y-N2 57.41(11) Y-C-Si 143.8 (2). 


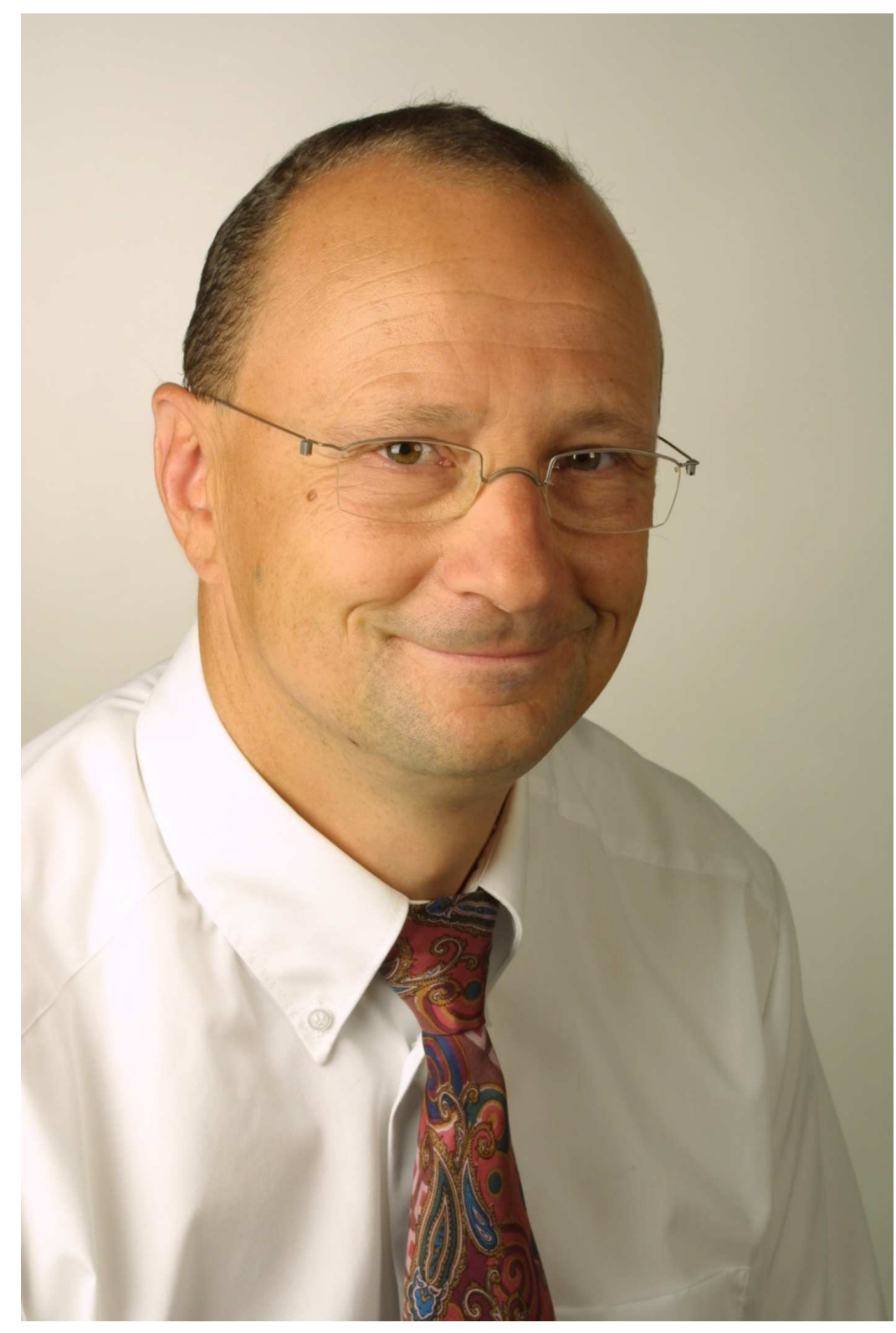

Please see CV. $59 \times 89 \mathrm{~mm}(600 \times 600 \mathrm{DPI})$ 


\title{
Rare Earth Polymerization Catalysts Supported by Bulky Aminopyridinato Ligands
}

\author{
Rhett Kempe \\ Anorganische Chemie II \\ Universität Bayreuth \\ 95440 Bayreuth \\ Mail:kempe@uni-bayreuth.de
}

\section{Rhett Kempe}

Rhett Kempe was born in Dresden in 1964. He studied chemistry at the Universität Leipzig including research stays in Jena (Prof. D. Walther) und Stuttgart (Prof. H.-G. von Schnering) and received his $\mathrm{PhD}$ degree (organo nickel chemistry) under the supervision of Prof. J. Sieler (1989). During a DAAD postdoctoral research fellowship at MIT (1992/1993) with Prof. R. R. Schrock he became interested in N2 activation. After a period at the MPI für Kohlenforschung in Mülheim (1993/1994) he begun to study for his habilitation in the MaxPlanck-Gesellschaft Group “Complex Catalysis” led by Prof. U. Rosenthal. The habilitation (amido metal chemistry) followed at the Universität Rostock in 1998. He worked as a group leader in the Institut für Organische Katalyseforschung Rostock (IfOK) for two years and then moved as a visiting scientist in 2000/2001 to the University of Melbourne (Prof. R. Robson's group). He became a Professor of Inorganic Chemistry at the University of Oldenburg in 2001 and was appointed to a Chair of Inorganic Chemistry at the University of Bayreuth in 2002. In 2006 he obtained an offer from the University of Rostock to hold the Chair of Inorganic Chemistry at this university and to join the Leibniz-Institute of Catalysis Rostock (LIKAT) and decided to stay in Bayreuth. His research interest is the development of novel catalyst systems. He is an author of more than 300 publications and was awarded, for instance, the Karl-Winnacker-Stipendium and the Heisenberg-Stipendium. 


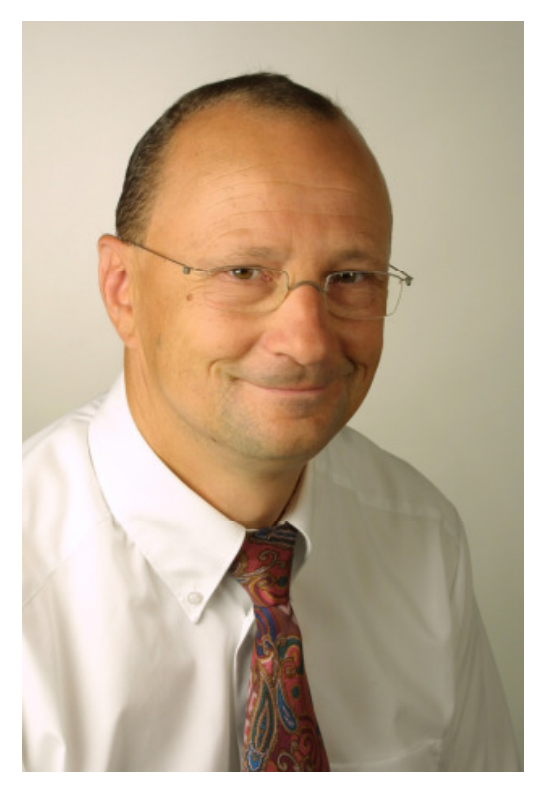

\section{Abstract}

The coordination and polymerization chemistry of molecular rare earth catalysts stabilized by bulky aminopyridinato (= Ap) ligands are reviewed. The selective synthesis of dialkyls allows the generation of rare earth alkyl hydride clusters and the generation of organo rare earth cations. These cations are able to catalyze polyethylene chain growing at aluminum and are able to polymerize isoprene stereoselectively. Complexes of the type $\left[\mathrm{ApLn}(\mathrm{thf})_{\mathrm{m}} \mathrm{X}_{2}\right](\mathrm{X}=\mathrm{Cl}$, $\mathrm{Br} ; \mathrm{m}=2,3$ ) allow controlled ring opening polymerization of $\varepsilon$-caprolactone in the presence of $\mathrm{NaBH}_{4}$. $\alpha, \omega$-Dihydroxytelechelic polymers are obtained. Bis-Ap alkyl complexes undergo $\mathrm{C}-\mathrm{H}$ activation of one of the methyl groups of the Ap ligand. The rates of this activation reaction depend strongly from the nature of the "leaving" ligand and the radius of the rare earth ion that mediates $\mathrm{C}-\mathrm{H}$ activation.

\section{Introduction}

Aminopyridatinato (= Ap) ligands, ${ }^{1}$ deprotonated 2-aminopyridines that coordinate in a strained $\eta^{2}$ binding mode, ${ }^{2}$ are amido type ligands that have received a lot of attention within the last decade. Meanwhile stable complexes for nearly all transition metals could be synthesized emphasizing the very general applicability of the ligand class. ${ }^{3}$ Rather close related ligands are amidinates, guanidinates, and NacNac ligands (Scheme 1). 
<smiles></smiles><smiles>[R]N=C([R])N[R]</smiles><smiles>[R]N=C(N=[N-])N([R])[R]</smiles><smiles>[R]N=C([R])/C=C(/[R])N[R]</smiles>

Scheme 1. Aminopyridinates (top, left) and the closely related amidinates (top, right), guanidinates (bottom, left), and NacNac ligands (bottom, right). R and R' denote substituents like alkyl, aryl, and alkylsilyl moieties.

The coordination chemistry of the aminopyridinato ligands is summarized until $2003 .{ }^{1}$ The ligands used until then were mainly rather low regarding their steric bulk and not very well suited to stabilize highly reactive neutral or cationic organo rare earth ${ }^{4}$ complexes. In consequence, new types of aminopyridinato ligands that incorporate a number of 2,6dialkylphenyl substituents on the ligand backbone were developed. ${ }^{5}$ The ligand periphery can be readily modified and these very bulky ligands should be utilized in probing key issues in amido lanthanoid and early transition metal catalysts such as deleterious ligand redistribution reactions (as have commonly thwarted lanthanide amide chemistry) and active site monomerdimer pre-equilibria. The ligands are synthesized in a two step procedure - first, a nickel complex catalyzed Grignard (Kumada-type) coupling reaction, followed by Pd catalyzed aryl amination chemistry (Scheme 2).<smiles>[R]c1cc([R])c(Br)c([R])c1</smiles>

1. $\mathrm{Mg}$

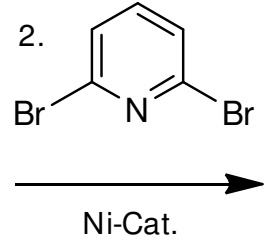<smiles>[R]c1cc([R])c(-c2cccc(Br)n2)c([R])c1</smiles><smiles>[R]c1cc([R])c(-c2cccc(Br)n2)c([R])c1</smiles>

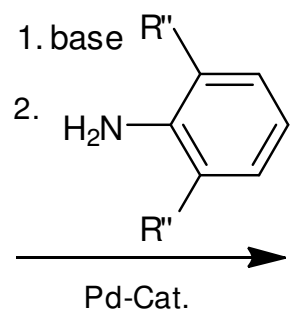<smiles>[R]c1cc([R])c(-c2cccc(Nc3c([R])cccc3[R])n2)c([R])c1</smiles>

Scheme 2. Synthesis of very bulky aminopyridines (R, R' and R' = alkyl substituents).

The bulkiest aminopyridine synthesized so far is N-(2,6-diisopropylphenyl)-6-(2,4,6triisopropylphenyl)pyridin-2-amine $\left(=\mathrm{Ap}^{*}-\mathrm{H}\right)$. The steric demand of the Ap* ligand is large. 
The maximum atom-to-atom distance in $\mathrm{Ap}^{*}$ is $15 \AA$ (a in Scheme 3 ) and approximately perpendicular to it about $\mathrm{b}=8 \AA$ ( $\mathrm{b}$ in Scheme 3 ). Comparing this distances with these of the bulky $\eta^{5}$-coordinated $\mathrm{Cp} *$ ligand which has a distance of $\mathrm{a}=\mathrm{b}=6.2 \AA$ for both directions, indicates that $\mathrm{Ap}^{*}$ and related ligands carrying other $\mathrm{R}$ groups should be effective for the protection of large metal ions.

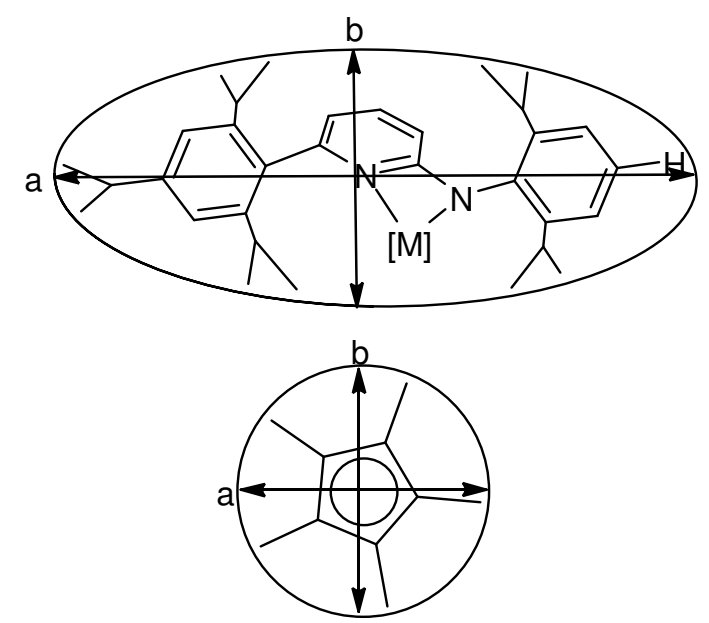

Scheme 3. Description of the steric demand of deprotonated Ap*-H in comparison to $\mathrm{Cp}^{*}$.

In consequence, it was thought these ligands might be ideal to stabilize highly reactive rare earth complexes which could also be useful polymerization catalysts. Especially interesting could be the fine tuning opportunity of the catalysts selectivity and activity by using the 17 rare earth ions available with only (slightly) different ionic radii and characteristics resulting from these differences.

In this review the state of the art of rare earth polymerization catalysts stabilized by bulky aminopyridinato ligands is summarized.

\section{Synthesis and Structure of Mono-Ap Halide Complexes}

The steric bulk of the Ap* ligand allows the selective synthesis of mono-Ap complexes even for the early lanthanoids. For instance, the salt metathesis reaction between the potassium salt of $\mathrm{Ap}^{*}-\mathrm{H}$ and $\mathrm{NdCl}_{3}$ gives $\left[\mathrm{Ap} * \mathrm{Nd}(\mathrm{thf})_{2} \mathrm{Cl}_{2}\right]_{2}$ in about $50 \%$ isolated yield of greenish lightblue crystals (Scheme 4). ${ }^{6}$ Interestingly, the reaction of a 2 to 1 ratio of $\mathrm{Ap}^{*} \mathrm{~K}$ to $\mathrm{NdCl}_{3}$ did result in the formation of the same compound. 
[Ap* $\mathrm{La}(\mathrm{thf})_{3} \mathrm{Br}_{2}$ ] is accessible selectively via salt elimination as well. A comparison of the structure of this dibromide with a closely related amidinate $\left[\mathrm{Am} * \mathrm{La}(\operatorname{thf})_{3} \mathrm{Br}_{2}\right]\left(\mathrm{Am}^{*}-\mathrm{H}=\mathrm{N}, \mathrm{N}-\right.$ bis-(2,6-diisopropylphenyl)-benzamidine) which was synthesized the same way revealed a similar overall primary coordination site bulkiness for both ligands and distinct differences regarding this bulkiness for different directions. A better shielding of the second coordination sphere was observed for the aminopyridinate. ${ }^{7}$ Interestingly, if a aminopyridinato ligand with a slightly smaller steric demand namely Ap+ $\{$ Ap+-H $=$ (2,6-diisopropylphenyl)-[6-(2,6dimethylphenyl)pyridin-2-yl]-amine the salt elimination reaction of the potassium salt of Ap+-H leads with $\mathrm{NdCl}_{3}$ selectively to bis-Ap complexes (Scheme 5). ${ }^{6}$

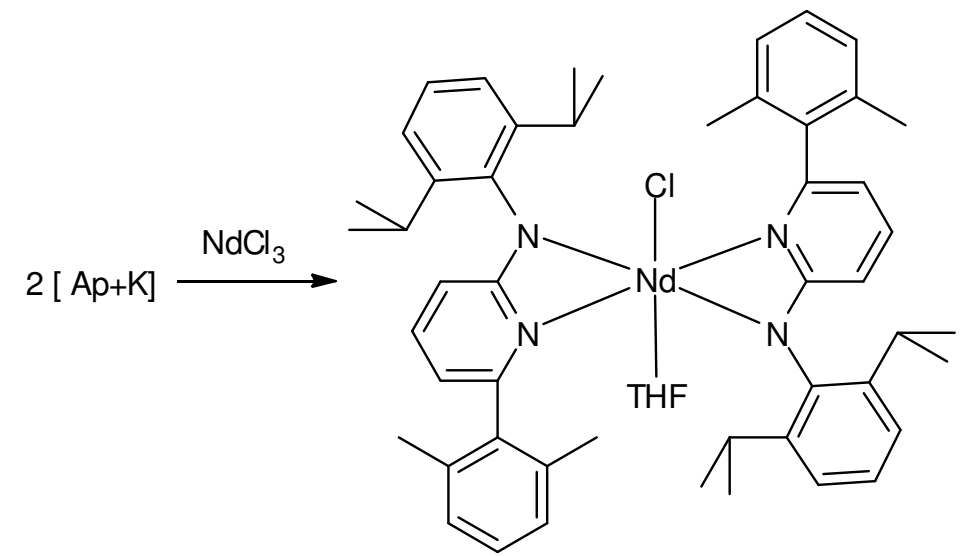

Scheme 5. Synthesis of $\left[\mathrm{Ap}+{ }_{2} \mathrm{Nd}(\mathrm{thf}) \mathrm{Cl}\right]$. 


\section{Alkylation and Hydride Formation of the Bis-Ap Complexes}

The activation of $\mathrm{C}-\mathrm{H}$ bonds and especially the activation of inert alkyls by transition metal or lanthanoid complexes is of a general interest due to its relevance for the functionalization of organic molecules. ${ }^{8}$ Complexes of the rare earth metals are strong Lewis acids which may attack the electron density of $\mathrm{C}-\mathrm{H}$ bonds, thus forming agostic ${ }^{9}$ interactions and activate $\mathrm{C}-\mathrm{H}$ bonds. It was even shown that methane could be activated by lanthanocene complexes such as $\left[\mathrm{Cp}_{2} \mathrm{LuCH}_{3}\right]^{10}{ }^{1}$ In consequence, intermolecular alkyl group $\mathrm{C}-\mathrm{H}$ activation of spectator ligands of lanthanoid complexes has been observed for a variety of ligands, for instance, for methyl groups of the $\mathrm{Cp}^{*}$ ligand $^{11}$ as well as for alkyl groups of ligands in non-metallocene lanthanoid complexes. ${ }^{12}$

The reaction $[\mathrm{Ap}+\mathrm{K}]$ with $\mathrm{YCl}_{3}$ proceeds selectively as the reaction with $\mathrm{NdCl}_{3}$ (Scheme 4) towards an Bis-Ap complex $\left[\mathrm{Ap}+{ }_{2} \mathrm{Y}(\mathrm{thf}) \mathrm{Cl}\right]$. It can be alkylated with $\left[\mathrm{LiCH}_{2} \mathrm{SiMe}_{3}\right]$ to give rise to the corresponding monoalkyl $\left[\mathrm{Ap}+{ }_{2} \mathrm{Y}(\mathrm{thf}) \mathrm{CH}_{2} \mathrm{SiMe}_{3}\right]$ (molecular structure Figure 1 left).

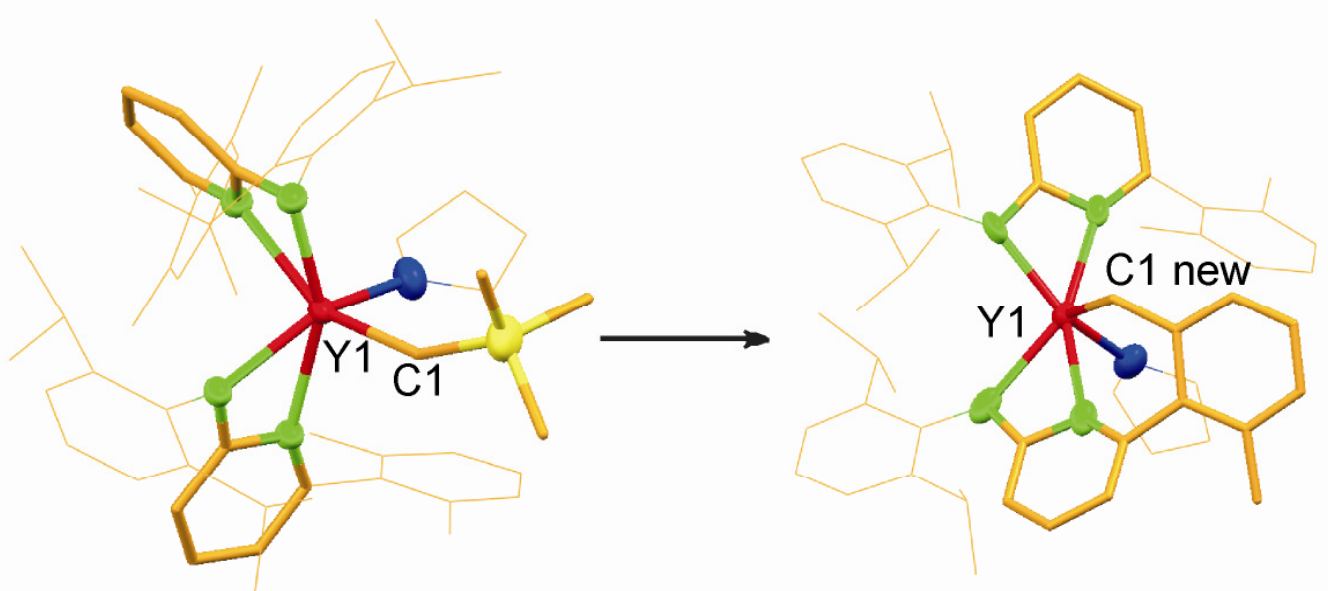

Figure 1. C-H activation of one of the methyl groups of $\mathrm{Ap}+$ in $\left[\mathrm{Ap}+{ }_{2} \mathrm{Y}(\mathrm{thf}) \mathrm{CH}_{2} \mathrm{SiMe}_{3}\right]$.

Interestingly, $\left[\mathrm{Ap}+{ }_{2} \mathrm{Y}(\right.$ thf $\left.) \mathrm{CH}_{2} \mathrm{SiMe}_{3}\right](\mathrm{Me}=$ methyl $)$ is not stable and undergoes a $\mathrm{C}-\mathrm{H}$ activation of one of the methyl groups of one of the Ap+ ligands. This intra-molecular $\mathrm{C}-\mathrm{H}$ activation seems entropically favoured and follows a first-order kinetic. ${ }^{13}$ The corresponding hydride $\left[\mathrm{Ap}+{ }_{2} \mathrm{Y}(\mathrm{thf}) \mathrm{H}\right]$, generated by the reaction of the $\left[\mathrm{Ap}+{ }_{2} \mathrm{Y}(\mathrm{thf}) \mathrm{CH}_{2} \mathrm{SiMe}_{3}\right]$ with $\mathrm{PhSiH}_{3}$ $(\mathrm{Ph}=$ phenyl $)$ undergoes an intramolecular metallation reaction very fast at room temperature. Intramolecular $s p^{3}$-hybridized $\mathrm{C}$-H activation of a hydride can be more than 500 times faster than that of an alkyl as judged by comparing the half times of the decomposition reactions (Scheme 6). 


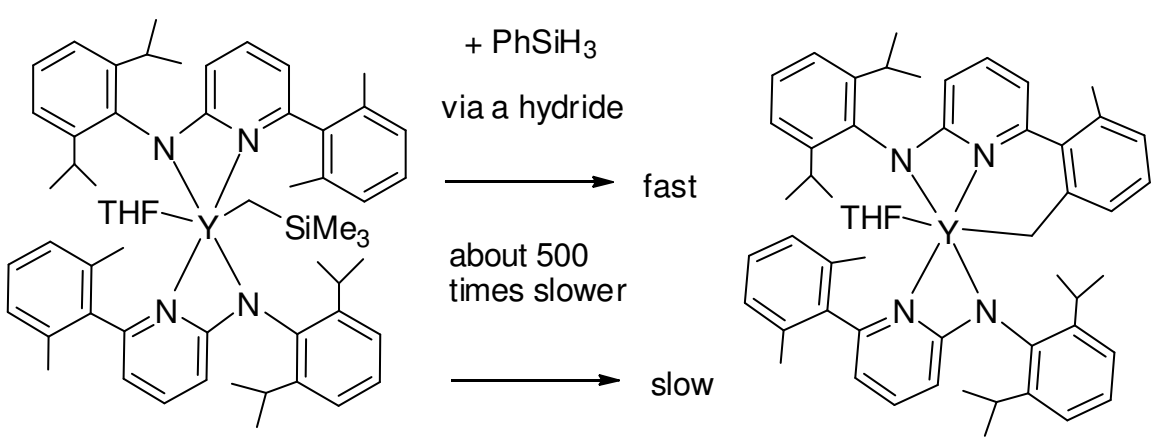

Scheme 6. Rates of C-H activation alkyl via transient hydride.

It was thought that this type of C-H activation should also proceed for the lanthanoids and due to their difference in size (ionic radii) one should see distinct differences in the rate of this reaction. Some general conclusions how the size of the lanthanoid ion influences the rate of a reaction (here a $\mathrm{C}-\mathrm{H}$ activation reaction which importance was given briefly at the beginning of this chapter) might be drawn. The following observations have been made. ${ }^{14}$

$\left[\mathrm{Ap}+{ }_{2} \mathrm{Sc}(\mathrm{thf}) \mathrm{CH}_{2} \mathrm{SiMe}_{3}\right]$ : The Sc alkyl is very stable and doesn't show any detectable decomposition when its $\mathrm{C}_{6} \mathrm{D}_{6}$ solution was monitored for several weeks. If it is reacted with $\mathrm{PhSiH}_{3}$ no conversion neither hydride formation nor $\mathrm{C}-\mathrm{H}$ activation is observed.

$\left[\mathrm{Ap}+{ }_{2} \mathrm{Lu}(\mathrm{thf}) \mathrm{CH}_{2} \mathrm{SiMe}_{3}\right]$ : The alkyl converts very slowly at room temperature towards the C$\mathrm{H}$ activation product. Stirring of the Lu alkyl in toluene with $\mathrm{PhSiH}_{3}$ for three days at room temperature allowed the isolation of its $\mathrm{C}-\mathrm{H}$ activation product in $60 \%$ yield.

$\left[\mathrm{Ap}+{ }_{2} \mathrm{Ln}(\mathrm{thf}) \mathrm{CH}_{2} \mathrm{SiMe}_{3}\right](\mathrm{Ln}=\mathrm{Nd}, \mathrm{La})$ : In contrast to $\mathrm{Sc}$ and $\mathrm{Lu}$ the alkylation of the chloro complexes $\left[\mathrm{Ap}+{ }_{2} \mathrm{Ln}(\mathrm{thf}) \mathrm{Cl}\right]$ of the larger lanthanoid ions $\mathrm{La}$ and $\mathrm{Nd}$ with one equivalent of $\left[\mathrm{LiCH}_{2} \mathrm{SiMe}_{3}\right]$ did not yield the desired alkyl complexes $\left[\mathrm{Ap}+{ }_{2} \mathrm{Ln}(\mathrm{thf}) \mathrm{CH}_{2} \mathrm{SiMe}_{3}\right]$ and led directly to the intramolecular $\mathrm{C}-\mathrm{H}$ bond activated products in isolated yields of around $60 \%$. $\mathrm{C}-\mathrm{H}$ activation of the alkyl already proceeds to fast to isolate it.

\section{Alkylation and Hydride Formation of the Mono-Ap Complexes}

The selective formation of mono-Ap dihalide complexes if the Ap* ligand is used ${ }^{6}$ (Scheme 4) may also allow to synthesize dialkys selectively. Two routes can be employed: salt metathesis ${ }^{15}$ and alkane elimination, ${ }^{16}$ as shown for $\mathrm{Y}$ and Lu (Scheme 7). 


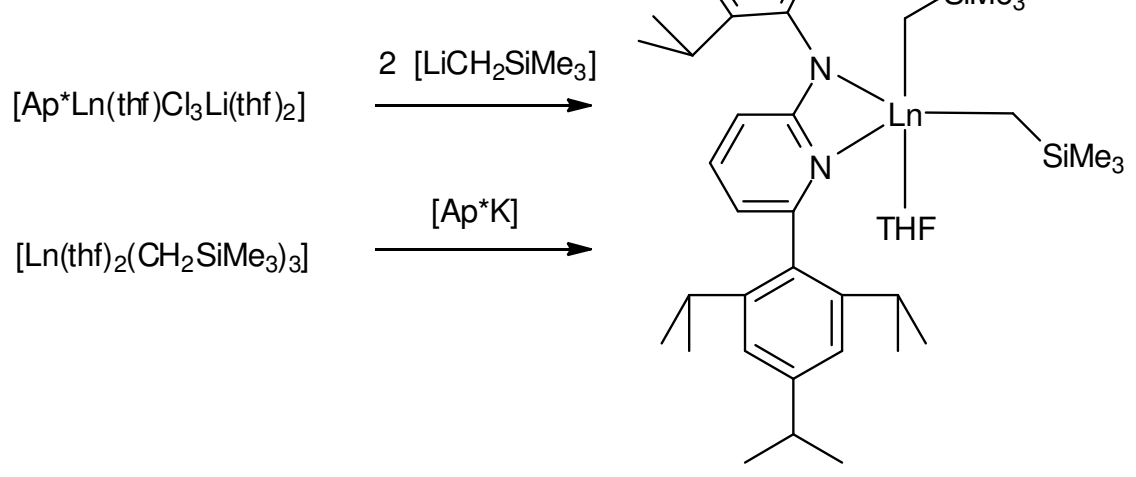

Scheme 7. Synthesis of mono-Ap dialkyls ( $\mathrm{Ln}=\mathrm{Lu}$ and $\mathrm{Y})$.

Alkane elimination is highly efficient and affords very good yield of the dialkyls. Unfortunately, it is difficult to isolate the starting material for the early lanthanoids. Salt metathesis can be employed throughout the whole series but usually affords lower yields. These dialkyls are stable and do not undergo C-H activation reactions of any of the methyl groups of the aminopyridinato ligand. They react with $\mathrm{H}_{2}$ and $\mathrm{PhSiH}_{3}$ selectively and form polynuclear hydride alkyl compounds (Scheme 8). ${ }^{15}$

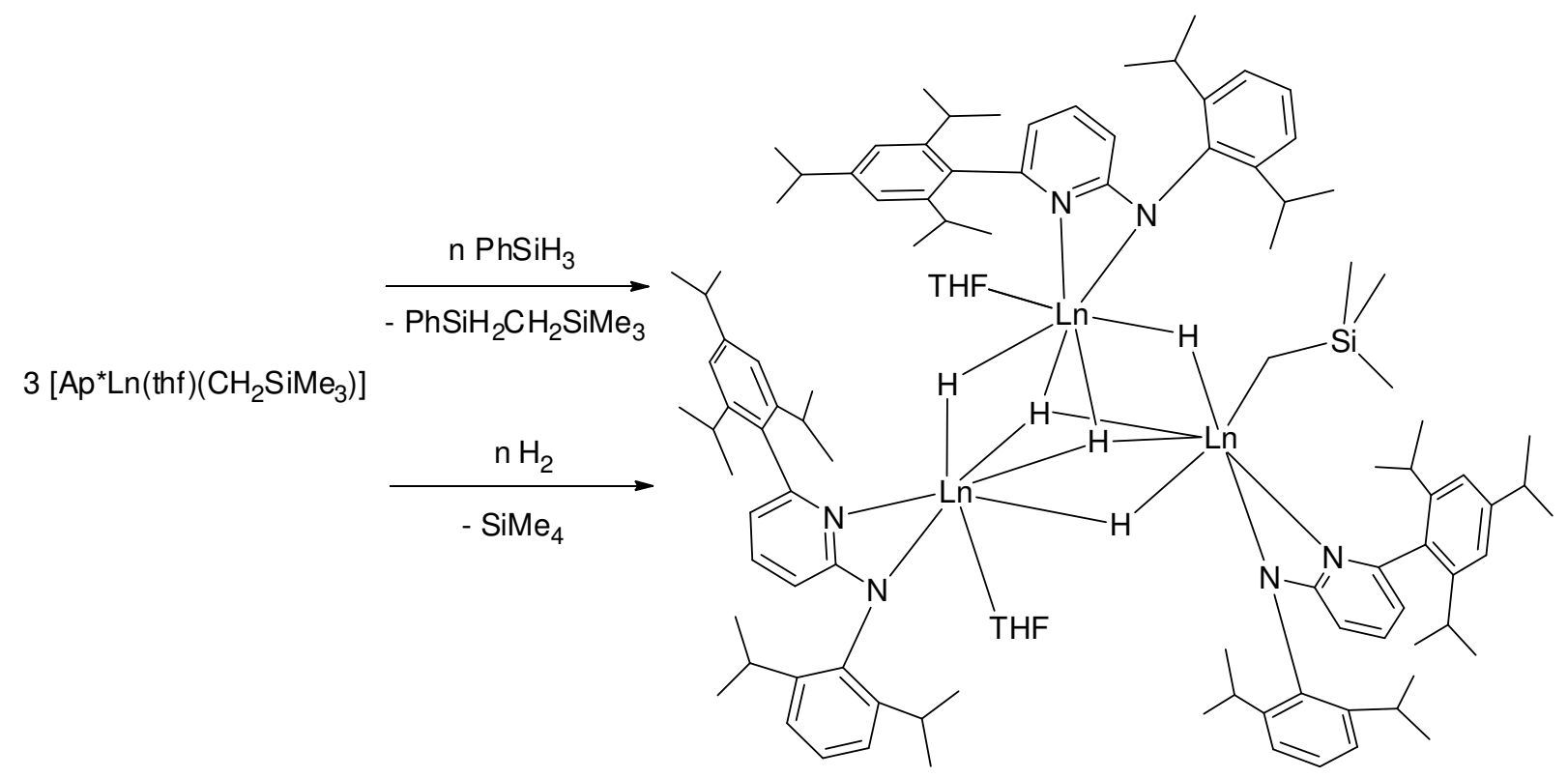

Scheme 8 . Synthesis of polynuclear hydride alkyl compounds.

Molecular rare earth metal hydrides are a fascinating class of compounds that posses a variety of unique structural and chemical properties. ${ }^{17}$ Assembly of trinuclear tetrahydride rare earth ate species $\left\{\left[\mathrm{Cp}_{2} \mathrm{LnH}\right]_{3} \mathrm{H}\right\}\left\{\mathrm{Li}(\text { thf })_{4}\right\}$ was reported already in the early 1980 s. ${ }^{18}$ The first 
"mono(cyclopentadienyl) dihydrido" complexes were reported in $1999^{19}$ and the area started blooming in $2001 .^{20}$ Meanwhile structural data obtained via neutron diffraction gave a very reliable picture of the $\mathrm{H}$ atom positions in these molecules. ${ }^{21}$ The hydride alkyl clusters formed by the reaction of mono-Ap stabilized dialkyls had been unique at this time. Usually, pure hydride clusters are formed. ${ }^{17}$ The molecular structure of $\left[\left(\mathrm{Ap}^{*} \mathrm{Y}\right)_{3}\left(\mu^{2}-\mathrm{H}\right)_{3}\left(\mu^{3}-\right.\right.$ $\left.\mathrm{H})_{2}\left(\mathrm{CH}_{2} \mathrm{SiMe}_{3}\right)(\text { thf })_{2}\right)$ ] is shown in Figure 2.

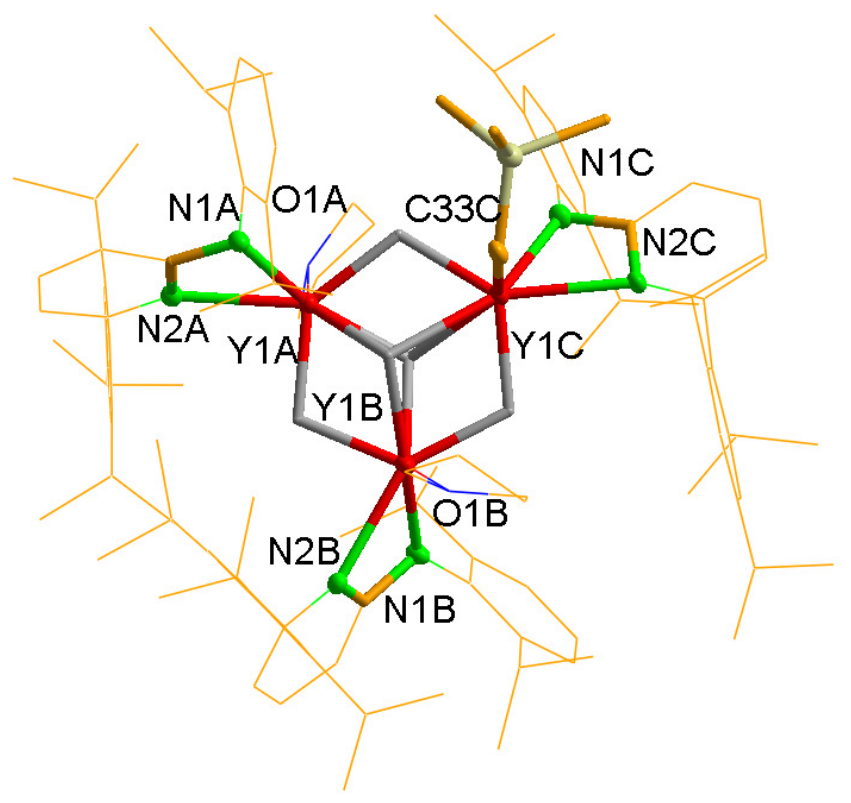

Figure 2. Molecular structure of $\left.\left[\left(\mathrm{Ap}^{*} \mathrm{Y}\right)_{3}\left(\mu^{2}-\mathrm{H}\right)_{3}\left(\mu^{3}-\mathrm{H}\right)_{2}\left(\mathrm{CH}_{2} \mathrm{SiMe}_{3}\right)(\mathrm{thf})_{2}\right)\right]$. The iPr groups of the Ap* ligands are omitted. Selected bond lengths $[\AA]$ and angles $\left[{ }^{\circ}\right]$ : $\mathrm{Y}(1 \mathrm{~A})-\mathrm{N}(1 \mathrm{~A})$ 2.323(2), $\mathrm{Y}(1 \mathrm{~A})-\mathrm{N}(2 \mathrm{~A})$ 2.459(2), $\mathrm{Y}(1 \mathrm{~A})-\mathrm{Y}(1 \mathrm{~B}) 3.4408(4), \mathrm{Y}(1 \mathrm{~A})-\mathrm{Y}(1 \mathrm{C}) 3.5158(4), \mathrm{Y}(1 \mathrm{~B})-$ $\mathrm{N}(1 \mathrm{~B})$ 2.307(2), Y(1B)-O(1B) 2.3510(19), Y(1B)-N(2B) 2.477(2), Y(1B)-Y(1C) 3.5058(4), $\mathrm{Y}(1 \mathrm{C})-\mathrm{N}(1 \mathrm{C})$ 2.331(2), Y(1C)-C(33C) 2.402(3), Y(1C)-N(2C) 2.503(2), Y(1B)-Y(1A)-Y(1C) 60.512(8), N(1A)-Y(1A)-N(2A) 56.70(8), N(1B)-Y(1B)-N(2B) 56.64(7), N(1C)-Y(1C)$\mathrm{N}(2 \mathrm{C}) 56.40(7)$.

\section{Low Valent Lanthanoid Aminopyridinates}

Due to the selective formation of mono- or bis-Ap complexes for the three valent rare earth atoms depending from the steric demand of the Ap ligands a similar selectivity was expected for the two valent lanthanoids. Lanthanoids which a rather stable in the two valent oxidation 
state like $\mathrm{Eu}, \mathrm{Yb}$ and $\mathrm{Sm}$ allow for the selective synthesis of mono-Ap complexes (Scheme 9). ${ }^{6,22}$

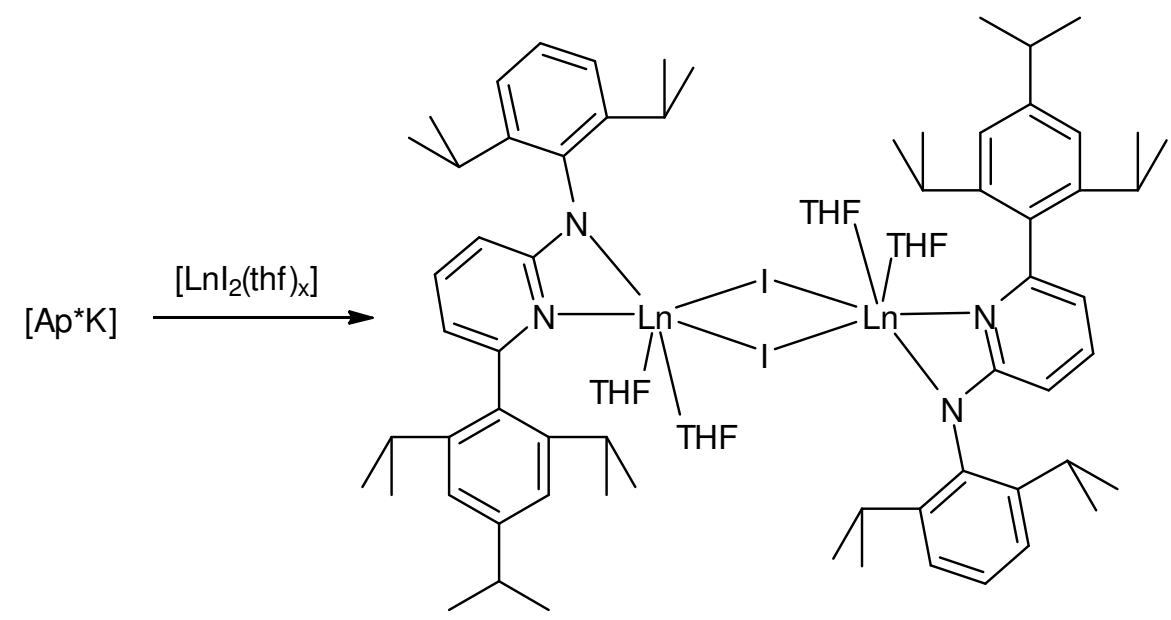

Scheme 9. Synthesis of $\left[\mathrm{Ap} * \operatorname{Ln}(\operatorname{thf})_{2} \mathrm{I}\right]_{2}(\mathrm{Ln}=\mathrm{Sm}, \mathrm{Yb}, \mathrm{Eu})$.

Attempts to reduce $\left[\mathrm{Ap} * \operatorname{Ln}(\mathrm{thf})_{2} \mathrm{I}\right]_{2}(\mathrm{Ln}=\mathrm{Eu}, \mathrm{Yb})$ with the intention to form a unsupported felement-f-element bond failed. Redistribution products of the type $\left[\mathrm{Ap}_{2}{ }_{2} \operatorname{Ln}(\operatorname{thf})_{2}\right]$ were isolated instead. $^{22}$

The "direct reaction" between lanthanoid metal and bulky aminopyridines is an effective and simple way to synthesize truly homoleptic aminopyridinates of $\mathrm{Yb}$. The used "direct reaction" synthetic method ${ }^{23}$ is especially valuable for homoleptic lanthanoid organoamides and phenolates ${ }^{24}$ and has recently been extended to analogous alkaline earth complexes. ${ }^{25}$ Again, the steric demand of the Ap ligand opens and closes different reaction pathways. The use of relatively less bulky Ap-H (Ap-H = N,6-dimesitylpyridin-2-amine) resulted in the formation of a six coordinated trivalent $\mathrm{Yb}$ complex $\left[\mathrm{Ap}_{3} \mathrm{Yb}\right]$ whereas more bulky aminopyridine Ap+$\mathrm{H}$ afforded a low coordinate divalent $\mathrm{Yb}$ compound $\left[\mathrm{Ap}+{ }_{2} \mathrm{Yb}\right]($ Scheme 10$){ }^{26}$ 


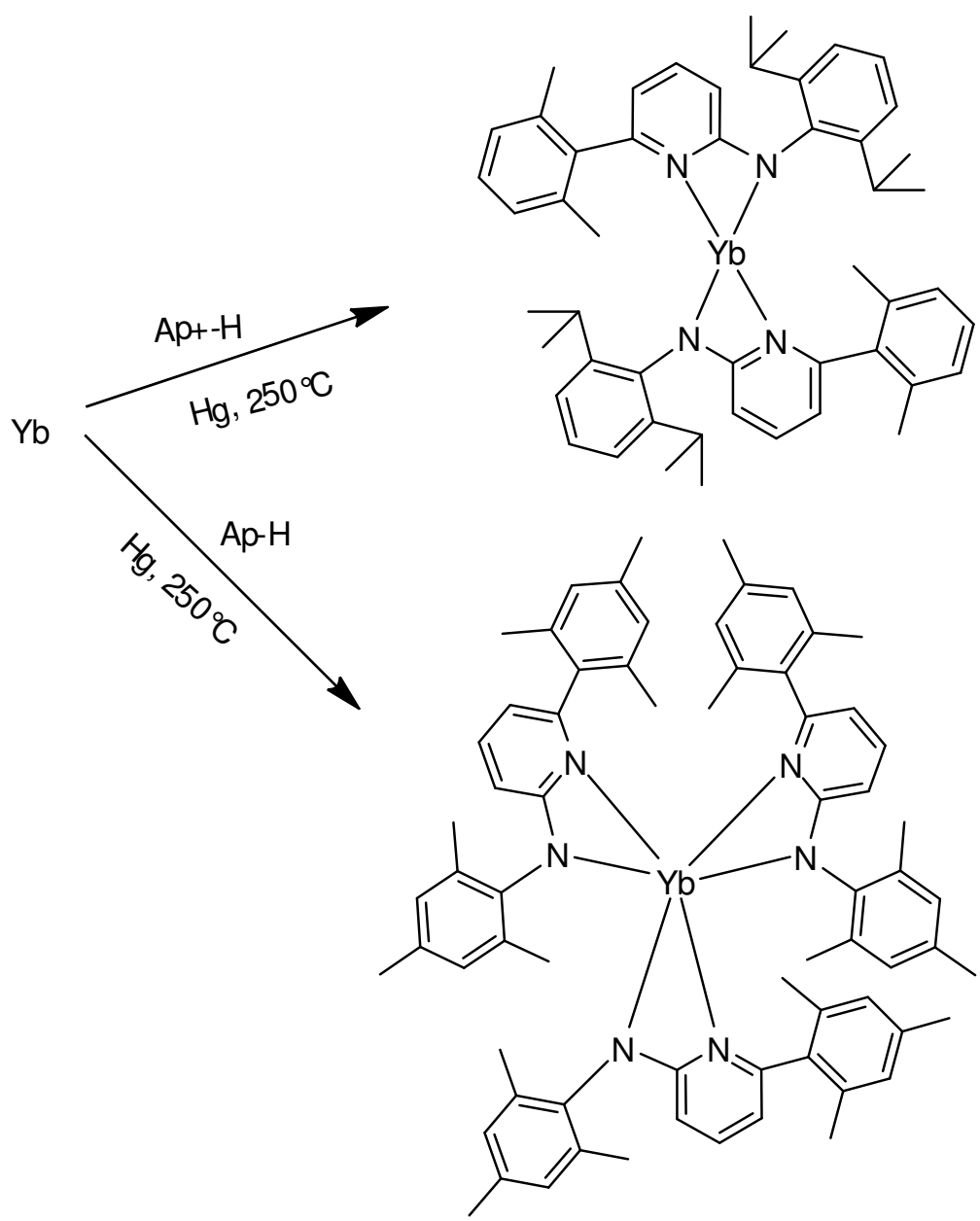

Scheme 10. Synthesis of $\left[\mathrm{Ap}_{3} \mathrm{Yb}\right]$ and $\left[\mathrm{Ap}+{ }_{2} \mathrm{Yb}\right]$.

Compound $[\mathrm{Ap}+2 \mathrm{Yb}]$ is a very low coordinated species and shows an intermolecular $\mathrm{C}_{\mathrm{Aryl}}-\mathrm{H}$ agostic interactions in the solid state (Figure 3).

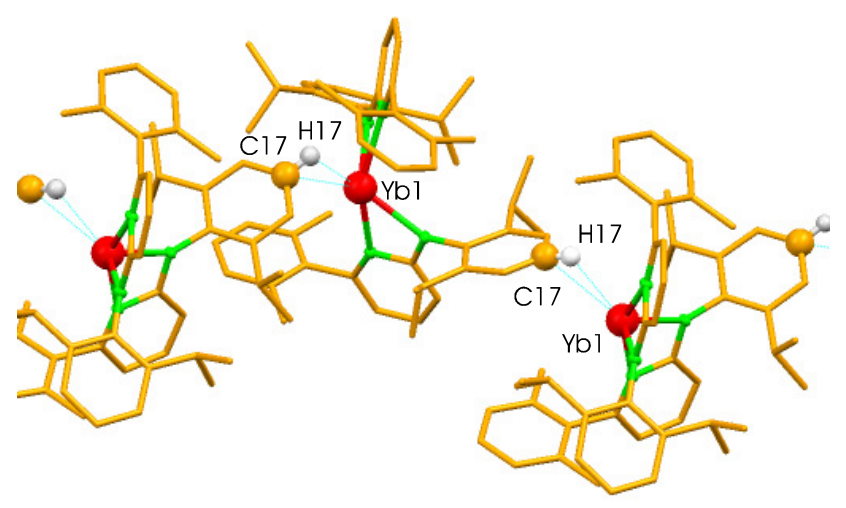

Figure 3. Solid state structure of $\left[\mathrm{Ap}+{ }_{2} \mathrm{Yb}\right]$ showing an intermolecular agostic interactions

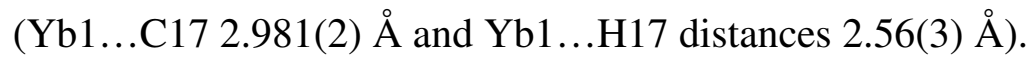


Salt metathesis using the potassium salt of the Ap ligand and $\left[\mathrm{YbI}_{2}(\text { thf })_{\mathrm{x}}\right]$ gives rise to other products namely five coordinate $\left[\mathrm{Ap}+{ }_{2} \mathrm{Yb}(\mathrm{thf})\right]$ and six coordinate $\left[\mathrm{Ap} \mathrm{p}_{2} \mathrm{Yb}(\mathrm{thf})_{2}\right]{ }^{26}$

\section{Di- and Trivalent Rare Earth Aminopyridinates as Initiators in the Ring-Opening Polymerization Reactions of $\varepsilon$-Caprolactone}

Ring-opening polymerization (ROP) is a potent synthetic tool for the synthesis of specific well-defined high molar mass polyesters ${ }^{27}$ and rare earth initiated coordination-insertion ROP has attracted considerable interest. ${ }^{28}$ Research activities on the design of more elaborated and most often more sophisticated rare earth complexes have enabled impressive progress in both the organic catalysis and polymerization chemistry. Much effort nowadays are driven by environmental concerns, getting more and more into the scope of green chemistry and biocompatibility concepts. ${ }^{29}$ Homoleptic trisborohydride rare earth complexes, $\left[\mathrm{Ln}\left(\mathrm{BH}_{3}\right)_{3}(\mathrm{thf})_{3}\right]^{30} \quad(\mathrm{Ln}=$ lanthanide $)$ are efficient initiators for the ring-opening polymerization of $\varepsilon$-caprolactone (CL), such borohydride initiators have subsequently been extended to organometallic derivatives such as $\left[\mathrm{Sm}\left(\mathrm{C}_{5} \mathrm{Me}_{5}\right)_{2}(\mathrm{thf})\right]$ for the polymerization of lactones. ${ }^{31}$ Furthermore, rare earth complexes involving aminopyridinato ligands of low steric demand have been synthesized and evaluated in polymerization of CL with the hope to improve the control of the polymerization process and a linear relation between the monomer to intiator ratio and the molecular weight of the polymer was observed. ${ }^{32}$ Ring-opening polymerization of $\varepsilon$-caprolactone initiated by complexes like [Ap* $\mathrm{La}(\mathrm{thf})_{3} \mathrm{Br}_{2}$ ] or $\left[\mathrm{Ap} * \mathrm{Yb}(\text { thf })_{2} \mathrm{I}\right]_{2}$ in the presence of $\mathrm{NaBH}_{4}$ allowing the preparation, in a controlled process and in a short reaction time, of $\alpha, \omega$-dihydroxytelechelic polymers with high molar mass $(\overline{\mathrm{M}} \mathrm{n}$ up to 50000$)$ and moderate molar mass distributions $(1.3<\overline{\mathrm{M}} \mathrm{w} / \overline{\mathrm{M}} \mathrm{n}<1.6){ }^{33}$ 
Interestingly, the polymerization of $\varepsilon$-caprolactone (CL) initiated by either the lanthanum or the ytterbium aminopyridinato halide complexes $\left[\mathrm{Ap} * \mathrm{La}\left(\operatorname{thf}_{3} \mathrm{Br}_{2}\right]\right.$ and $\left[\mathrm{Ap} * \mathrm{Yb}(\operatorname{thf})_{2} \mathrm{I}\right]_{2}$ in absence of any coinitiator $\left(\mathrm{NaBH}_{4}\right)$, at room temperature over 4 hours in THF, allows the preparation of poly( $\varepsilon$-caprolactone) (PCL) but only with rather low control. Very high molar mass polymers $\left(120000<\overline{\mathrm{M}} \mathrm{n}_{\mathrm{SEC}}<170000 ; \overline{\mathrm{M}} \mathrm{n}_{\mathrm{SEC}}=\overline{\mathrm{M}}\right.$ determined by size exclusion chromatography (SEC)) with large molar mass distribution values ( $\overline{\mathrm{M}} \mathrm{w} / \overline{\mathrm{M}} \mathrm{n}$ ) ranging from 1.4 to 1.7$)$ were observed. The polymerization of $\mathrm{CL}$ using $\left[\mathrm{Ap} * \mathrm{Lu}(\mathrm{thf})_{2} \mathrm{Cl}_{2}\right.$ ] under the same conditions did not result in polymers. These results are not surprising since up to then it had been challenging to establish homopolymerization of CL with rare earth halide complex in a highly controlled fashion..$^{34,35,36}$ The search for potential impurities did not give an explanation why the La complex initiates but the Lu complex does not. In presence of $\mathrm{NaBH}_{4}$ the polymerization initiated by $\left[\mathrm{Ap} * \mathrm{La}(\text { thf })_{3} \mathrm{Br}_{2}\right],\left[\mathrm{Ap} * \mathrm{Yb}(\mathrm{thf})_{2} \mathrm{I}\right]_{2}$, and $\left[\mathrm{Ap} * \mathrm{Lu}(\text { thf })_{2} \mathrm{Cl}_{2}\right]$ give polymers with interesting features. Selected polymerization results are shown in Table 1, Table 2, and Table 3. 
Table 1. Polymerization of $\varepsilon$-CL in THF at $23^{\circ} \mathrm{C}$ over 4 hours using [Ap* $\mathrm{La}(\operatorname{thf})_{3} \mathrm{Br}_{2}$ ].

\begin{tabular}{|c|c|c|c|c|c|c|c|c|c|}
\hline $\begin{array}{c}{\left[\mathrm{NaBH}_{4}\right]_{0}} \\
/[\text { Initiator }]_{0}\end{array}$ & $\begin{array}{l}{\left[\text { Initiator }_{0}{ }^{a}\right.} \\
\left(\text { mmol.L }^{-1}\right)\end{array}$ & $\begin{array}{c}{\left[\mathrm{BH}_{4}\right]_{0}} \\
\left(\mathrm{mmol}_{\mathbf{L}} \mathbf{L}^{-1}\right)\end{array}$ & $\begin{array}{c}{[\varepsilon-\mathrm{CL}]_{0}} \\
\left(\mathrm{mmol}^{\left.-\mathrm{L}^{-1}\right)}\right.\end{array}$ & $\begin{array}{c}{[\varepsilon-\mathbf{C L}]_{0} /} \\
{\left[\mathrm{BH}_{4}\right]_{0}{ }^{a}}\end{array}$ & $\begin{array}{c}\text { Monomer } \\
\text { Conv. }^{b} \\
(\%)\end{array}$ & $\begin{array}{c}\overline{\mathrm{Mn}}{ }_{\text {theo }}{ }^{c} \\
\left(\text { g.mol }^{-1}\right)\end{array}$ & $\begin{array}{c}\overline{\mathrm{M}} \mathrm{SEC}^{d} \\
\left(\mathrm{~g} \cdot \mathbf{m o l}^{-1}\right)\end{array}$ & $\begin{array}{c}\overline{M n}_{\text {NMR }}{ }^{\mathrm{f}} \\
\left(\mathrm{g} \mathrm{mol}^{-1}\right)\end{array}$ & $\overline{\mathbf{M}} \mathbf{w} / \overline{\mathbf{M}} \mathbf{n}^{e}$ \\
\hline 0 & 7.6 & 0 & 410.2 & 54 & 85 & 5200 & 167600 & - & 1.4 \\
\hline 0 & 3.8 & 0 & 410.2 & 108 & 90 & 11100 & 168600 & - & 1.5 \\
\hline 1.0 & 9.6 & 9.3 & 1002 & 108 & 99 & 12200 & 16000 & 18900 & 1.3 \\
\hline 1.0 & 8.9 & 8.8 & 1002 & 114 & 98 & 12700 & 15700 & 19000 & 1.3 \\
\hline 2.0 & 5.4 & 10.0 & 4500 & 450 & 99 & 50800 & 46300 & 45600 & 1.5 \\
\hline 3.0 & 2.5 & 7.9 & 722.0 & 91 & 97 & 10050 & 17000 & 15700 & 1.4 \\
\hline \multicolumn{10}{|c|}{${ }^{a}[\text { Initiator }]_{0}=\left[\mathrm{Ap} * \mathrm{La}(\text { thf })_{3} \mathrm{Br}_{2}\right]_{0} ;\left[\mathrm{Ap} * \mathrm{Lu}(\text { thf })_{2} \mathrm{Cl}_{2}\right]_{0}$ or $\left[\left[\mathrm{Ap} * \mathrm{Yb}(\text { thf })_{2} \mathrm{I}_{2}\right]_{0} ;\right.$ in absence of $\mathrm{NaBH}_{4},[\varepsilon-\mathrm{CL}]_{0} /\left[\mathrm{BH}_{4}\right]_{0}$} \\
\hline
\end{tabular}

Table 2. Polymerization of $\varepsilon$-CL in THF at $23^{\circ} \mathrm{C}$ over 4 hours using $\left[\mathrm{Ap} * \mathrm{Yb}(\mathrm{thf})_{2} \mathrm{I}\right]_{2}$.

\begin{tabular}{|c|c|c|c|c|c|c|c|c|c|}
\hline $\begin{array}{c}{\left[\mathrm{NaBH}_{4}\right]_{0}} \\
/[\text { Initiator }]_{0}\end{array}$ & $\begin{array}{l}{\left[\text { Initiator }_{0}{ }^{a}\right.} \\
\left(\text { mmol.L }^{-1}\right)\end{array}$ & 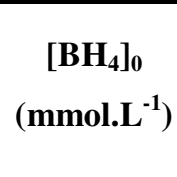 & $\begin{array}{c}{[\varepsilon-\mathrm{CL}]_{0}} \\
\left(\mathrm{mmol} . \mathbf{L}^{-1}\right)\end{array}$ & $\begin{array}{c}{[\varepsilon-\mathbf{C L}]_{0} /} \\
{\left[\mathrm{BH}_{4}\right]_{0}{ }^{a}}\end{array}$ & $\begin{array}{c}\text { Monomer } \\
\text { Conv. }^{b} \\
(\%)\end{array}$ & $\begin{array}{c}\overline{\mathrm{Mn}}{ }_{\text {theo }}{ }^{\mathrm{c}} \\
\left(\mathrm{g} \cdot \mathrm{mol}^{-1}\right)\end{array}$ & $\begin{array}{c}\bar{M} \text { SEC }^{d} \\
(\text { g.mol } \\
\left.{ }^{-1}\right)\end{array}$ & $\begin{array}{l}\overline{\mathbf{M n}_{\text {NMR }}}{ }^{\mathrm{f}} \\
\left(\mathrm{g} . \mathrm{mol}^{-1}\right)\end{array}$ & $\overline{\mathbf{M}} \mathbf{w} / \overline{\mathbf{M}} \mathbf{n}^{e}$ \\
\hline 0 & 4.2 & 0 & 410.2 & 98 & 85 & 9500 & 121700 & - & 1.7 \\
\hline 0 & 2.1 & 0 & 410.2 & 195 & 75 & 16700 & 128200 & - & 1.7 \\
\hline 2.1 & 4.8 & 9.9 & 1120 & 113 & 98 & 12600 & 34500 & 29000 & 1.6 \\
\hline 2.0 & 3.2 & 6.6 & 1120 & 170 & 98 & 19000 & 47500 & 35000 & 1.6 \\
\hline 4.0 & 4.2 & 16.9 & 1002 & 59 & 98 & 6600 & 13000 & 22000 & 1.5 \\
\hline 4.0 & 4.2 & 16.9 & 2000 & 118 & 98 & 13200 & 23000 & 28500 & 1.5 \\
\hline 4.0 & 2.5 & 9.5 & 5400 & 568 & 98 & 63400 & 43600 & 45600 & 1.6 \\
\hline
\end{tabular}

${ }^{a}[\text { Initiator }]_{0}=\left[\mathrm{Ap} * \mathrm{La}(\text { thf })_{3} \mathrm{Br}_{2}\right]_{0} ;\left[\mathrm{Ap} * \mathrm{Lu}(\text { thf })_{2} \mathrm{Cl}_{2}\right]_{0}$ or $\left[\left[\mathrm{Ap} * \mathrm{Yb}(\text { thf })_{2} \mathrm{I}_{2}\right]_{0}\right.$; in absence of $\mathrm{NaBH}_{4},[\varepsilon-\mathrm{CL}]_{0} /\left[\mathrm{BH}_{4}\right]_{0}$

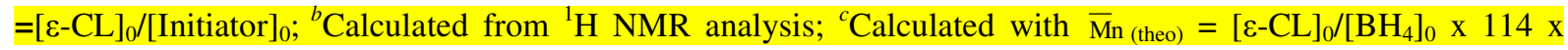
conversion; ${ }^{d} \mathrm{SEC}$ values of precipitated polymer samples corrected with the coefficient 0.56 ; ${ }^{\circ}$ Molar mass distribution calculated from SEC chromatogram traces; ${ }^{\mathrm{f}}$ Molar masses determined by NMR. 
Table 3. Polymerization of $\varepsilon$-CL in THF at $23^{\circ} \mathrm{C}$ over 4 hours using [Ap* $\mathrm{Lu}(\mathrm{thf})_{2} \mathrm{Cl}_{2}$ ].

\begin{tabular}{|c|c|c|c|c|c|c|c|c|c|}
\hline $\begin{array}{c}{\left[\mathrm{NaBH}_{4}\right]_{0}} \\
/[\text { Initiator }]_{0}\end{array}$ & $\begin{array}{l}{\text { Initiator }]_{0}^{a}}^{a} \\
\left(\text { mmol.L }^{-1}\right)\end{array}$ & $\begin{array}{c}{\left[\mathrm{BH}_{4}\right]_{0}} \\
\left(\mathrm{mmol}^{-L^{-1}}\right)\end{array}$ & $\begin{array}{c}{[\varepsilon-\mathrm{CL}]_{0}} \\
\left(\mathrm{mmol} . \mathrm{L}^{-1}\right)\end{array}$ & $\begin{array}{c}{[\varepsilon-\mathrm{CL}]_{0} /} \\
{\left[\mathrm{BH}_{4}\right]_{0}{ }^{a}}\end{array}$ & $\begin{array}{c}\text { Monomer } \\
\text { Conv. }^{b} \\
(\%)\end{array}$ & $\begin{array}{c}\overline{\mathrm{M}} \mathrm{n} \text { theo } \\
\left(\text { g.mol }^{-1}\right)\end{array}$ & $\begin{array}{c}\overline{\mathrm{M}} \mathrm{nSEC}^{d} \\
\left({\mathrm{~g} . \mathrm{mol}^{-1}}^{-1}\right)\end{array}$ & $\begin{array}{c}\overline{M n}_{\text {NMR }}{ }^{\mathbf{f}} \\
\left(\text { g.mol }^{-1}\right)\end{array}$ & $\overline{\mathbf{M}} \mathbf{w} / \overline{\mathbf{M}} \mathbf{n}^{e}$ \\
\hline 0 & 8.8 & 0 & 410.2 & 47 & $\overline{45}$ & 2400 & - & - & - \\
\hline 0 & 4.8 & 0 & 410.2 & 85 & 33 & 3200 & - & - & - \\
\hline 1.0 & 9.7 & 9.9 & 902.5 & 91 & 100 & 10400 & 17600 & 20700 & 1.6 \\
\hline 1.1 & 6.1 & 6.6 & 902.4 & 137 & 98 & 15300 & 16400 & 12500 & 1.5 \\
\hline 2.0 & 5.4 & 10.0 & 4500 & 450 & 99 & 50800 & 45600 & 51800 & 1.6 \\
\hline
\end{tabular}

${ }^{a}[\text { Initiator }]_{0}=\left[\mathrm{Ap} * \mathrm{La}(\text { thf })_{3} \mathrm{Br}_{2}\right]_{0} ;\left[\mathrm{Ap} * \mathrm{Lu}(\text { thf })_{2} \mathrm{Cl}_{2}\right]_{0}$ or $\left[\left[\mathrm{Ap} * \mathrm{Yb}\left(\text { thf }_{2}\right)_{2}\right]_{2}\right]_{0}$; in absence of $\mathrm{NaBH}_{4},[\varepsilon-\mathrm{CL}]_{0} /\left[\mathrm{BH}_{4}\right]_{0}$ $=[\varepsilon-\mathrm{CL}]_{0} /[\text { Initiator }]_{0} ;{ }^{b}$ Calculated from ${ }^{1} \mathrm{H}$ NMR analysis; ${ }^{c}$ Calculated with ${ }^{\mathrm{M}}{ }_{(\text {theo }}=[\varepsilon-\mathrm{CL}]_{0} /\left[\mathrm{BH}_{4}\right]_{0} \mathrm{x} 114 \mathrm{x}$ conversion; ${ }^{d} \mathrm{SEC}$ values of precipitated polymer samples corrected with the coefficient 0.56 ; ${ }^{\circ}$ Molar mass distribution calculated from SEC chromatogram traces; ${ }^{\mathrm{f}}$ Molar masses determined by NMR.

In presence of more than one equivalent of $\mathrm{NaBH}_{4}$ per metal centre, the polymerization proceeds smoothly as well and it is quite controlled especially for Lu and La. The experimental molar masses $\overline{\mathrm{M}} \mathrm{SEC}_{\mathrm{SEC}}$ and $\overline{\mathrm{M}} \mathrm{n}_{\mathrm{NMR}}$ give similar values and they are often in quite close agreement with the theoretical values ( $\left.\overline{\mathrm{M}} \mathrm{n}_{\text {theo }}\right)$. NMR analyses of the polymers recovered from the reactions done in the presence of $\mathrm{NaBH}_{4}$ showed the formation of $\alpha, \omega$ dihydroxytelechelic PCL. ${ }^{33}$ These results are indicative of a $\mathrm{Ln}-\mathrm{BH}_{4}$ bond which becomes the active site of the polymerization. It is interesting to mention that it was not possible to isolate the resulting borohydride compound from the reaction of $\left[\mathrm{Ap} * \mathrm{La}(\operatorname{thf})_{3} \mathrm{Br}_{2}\right]$ or [Ap* $\mathrm{Lu}(\mathrm{thf})_{2} \mathrm{Cl}_{2}$ ] with $\mathrm{NaBH}_{4}$ or $\mathrm{KBH}_{4}$. Due to the formation of $\alpha, \omega$-dihydroxytelechelic PCL a metal-alkoxide intermediate, where the $\mathrm{HBH}_{3}$ end group reduces the $\alpha$-carbonyl function is likely to be the initiating species ([Ln]- $\left.\left\{\mathrm{O}\left(\mathrm{CH}_{2}\right)_{5} \mathrm{CH}_{2} \mathrm{OBH}_{\mathrm{x}}\right\}\right)$. After the termination reaction, both the $\mathrm{Ln}-\mathrm{O}$ and the $-\mathrm{CH}_{2} \mathrm{OBH}_{\mathrm{x}}$ extremities are hydrolyzed into hydroxyl chain ends giving rise to a polymer that can be formulated as $\left[\mathrm{HO}\left(\mathrm{CH}_{2}\right)_{5} \mathrm{C}(\mathrm{O})\left\{\mathrm{O}\left(\mathrm{CH}_{2}\right)_{5} \mathrm{C}(\mathrm{O})\right\}_{\mathrm{n}-2} \mathrm{O}\left(\mathrm{CH}_{2}\right)_{6} \mathrm{OH}\right], \mathrm{HO}-\mathrm{PCL}-\mathrm{OH}$.

\section{Coordinative Chain Transfer Polymerization (CCTP) of Ethylene}

\section{Introduction}

The polymerization of ethylene especially in the low molecular weight range can be established in a highly controlled fashion by a chain growing process on a main group metal 
or zinc which is catalyzed by an organo transition metal or lanthanide complex - Coordinative Chain Transfer Polymerization (CCTP, Scheme 12). ${ }^{37}$ Chain growing takes place via ethylene insertion into the transition metal or lanthanide $\left[\mathrm{M}^{1}\right]$ carbon bond. The fast transferred chains "rest" at the main group or zinc centre $\left[\mathrm{M}^{2}\right]$ where chain termination processes like $\mathrm{B}-\mathrm{H}$ transfer/elimination are of low significance.

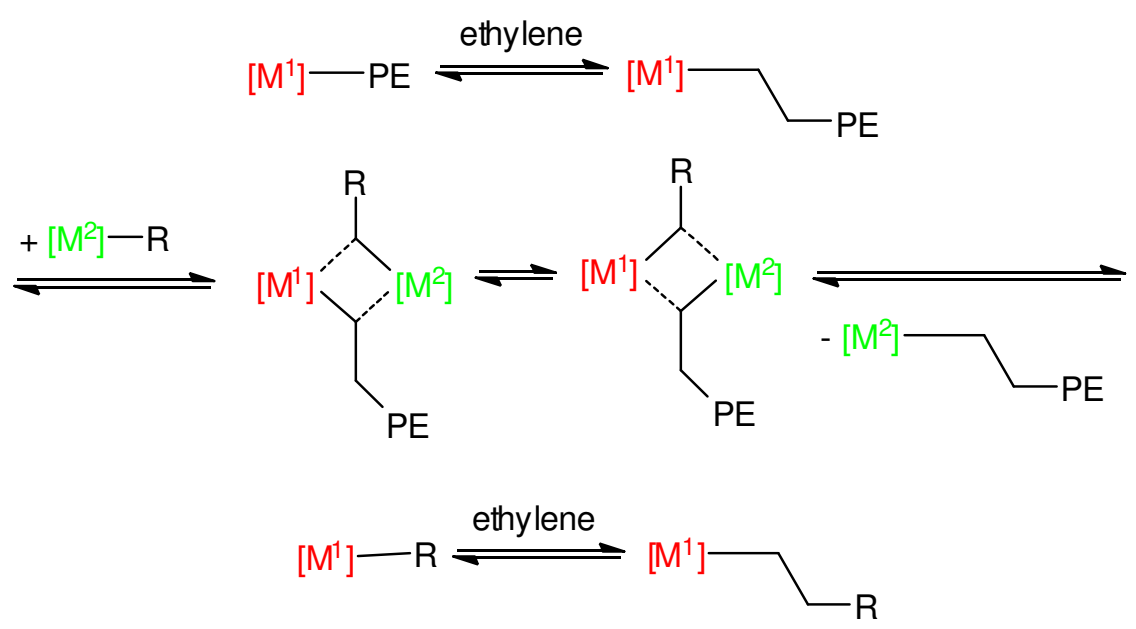

Scheme 12. CCTP.

Such a strategy appeared in the patent literature in the early 90s. A variety of metallocene based catalyst systems which catalyzed chain growing at Al alkyls were described. ${ }^{38}$ The first highly controlled catalyst system (rare earth/magnesium based) was introduced a few years later. ${ }^{39}$ Meanwhile a variety of catalysts that undergo CCTP is known. ${ }^{37,38,39,40,42,44,55}$ The equilibrium between chain transfer state (CTS) and chain growing state (CGS) is the basis of such a polymerization protocol and determines the overall productivity (Scheme 13). The CTS is essentially responsible for a very fast intra- [exchange of dashed and solid lines within the CTS (Scheme 12)] and intermolecular [exchange of MGM(R)(R')(R') units of the CTS] chain transfer. The CGS accomplishes the growing of a single chain. To achieve high control the chain transfer has to be faster than chain growing to avoid multiple insertions. If an excess of $\operatorname{MGM}(\mathrm{R})(\mathrm{R}$ ') $)(\mathrm{R}$ ') is present and if other chain termination processes like $\beta-\mathrm{H}$ transfer/elimination could be suppressed for the CGS a chain growing of all chains of all $\operatorname{MGM}(\mathrm{R})(\mathrm{R}$ ') $(\mathrm{R}$ ') molecules with nearly the same rate is observed (MGM = main group metal, or $\mathrm{Zn}$ ). Consequently, a very narrowly distributed MGM terminated PE material is observed. 


\section{The Ap Organoyttrium Cation Aluminum Catalyst System}

We had studied the polymerization of ethylene using organoyttrium cations ${ }^{41}$ as catalysts. These cations can be generated by following the procedure shown in Scheme $14{ }^{42}$
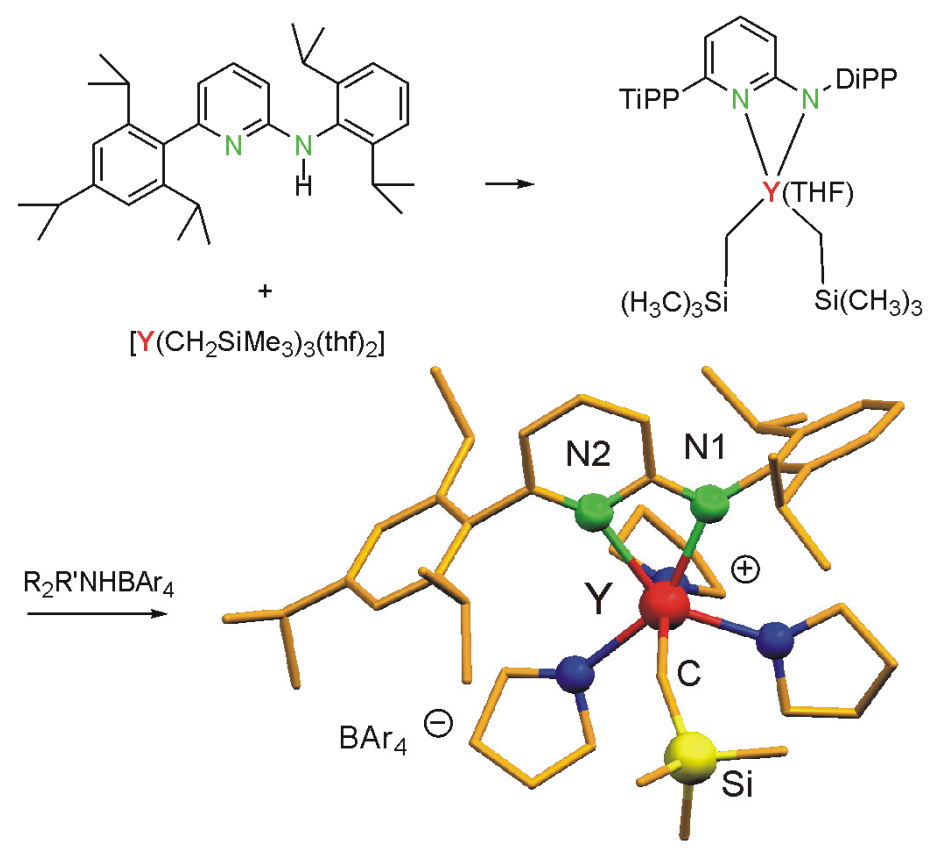

Scheme 14. Synthesis and molecular structure of $\left\{\left[\mathrm{Ap} * \mathrm{Y}(\mathrm{thf})_{3} \mathrm{CH}_{2} \mathrm{SiMe}_{3}\right]^{+}\left[\mathrm{B}\left(\mathrm{C}_{6} \mathrm{~F}_{5}\right)_{4}\right]^{-}\right\}$. The anion is simplified. Two independent cations per asymmetric unit were found; selected bond parameters [ $\left[\AA{ }^{\circ}\right.$ ] averaged: Y-N1 2.302(3), Y-N2 2.421(3), Y-C 2.382(4), N1-Y-N2 57.41(11) Y-C-Si 143.8 (2).

For ethylene polymerization experiments the ammonium borate $\left[\mathrm{R}_{2} \mathrm{~N}\left(\mathrm{CH}_{3}\right) \mathrm{H}\right]^{+}\left[\mathrm{B}\left(\mathrm{C}_{6} \mathrm{~F}_{5}\right)_{4}\right]^{-}(\mathrm{R}$ $\left.=\mathrm{C}_{16} \mathrm{H}_{31}-\mathrm{C}_{18} \mathrm{H}_{35}\right)$ and a Y/B ratio of $1 / 1.1$ were used. A comparison of the ethylene polymerization activity revealed that the steric bulk of the ligand is crucial (Table 4). 


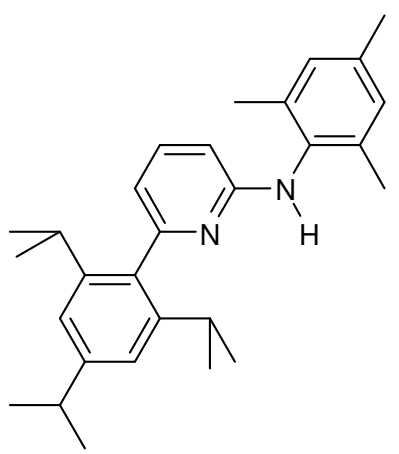

Scheme 15. Structure of $\mathrm{Ap}^{-}-\mathrm{H}$.

If Ap* is used to generate the organoyttrium cation catalyst the activity is the highest and for $\mathrm{Ap}^{+}$and $\mathrm{Ap}^{-}$(both ligands contain the inverse substitution pattern and the steric bulk could be considered as similar- Scheme 15) similar but lower activities were observed.

Table 4. Ethylene polymerization activity depending from the steric bulk of the Ap ligand.

\begin{tabular}{|c|c|c|c|c|}
\hline ligand & $\begin{array}{c}\mathbf{m}_{\text {Pol. }} \\
{[\mathrm{g}]}\end{array}$ & $\begin{array}{c}\text { activity } \\
{\left[\mathrm{kg}_{\mathrm{PE}} \mathrm{mol}_{\mathrm{Kat}}{ }^{-1} \mathrm{~h}^{-1} \mathrm{bar}^{-1}\right]}\end{array}$ & $\begin{array}{c}\mathbf{M}_{\mathbf{w}} \\
{\left[\mathrm{gmol}^{-1}\right]}\end{array}$ & $\mathbf{M}_{\mathbf{w}} / \mathbf{M}_{\mathbf{n}}$ \\
\hline Ap* & 13.4 & 1072 & $66500^{\mathrm{a}}$ & 3.2 \\
\hline $\mathrm{Ap}^{+}$ & 5.0 & 400 & $46100^{\mathrm{a}}\left(10800^{\mathrm{b}}\right)$ & $4.3(1.5)$ \\
\hline $\mathrm{Ap}^{-}$ & 5.4 & 432 & $263900^{\mathrm{a}}\left(16300^{\mathrm{b}}\right)$ & $28.8(2.4)$ \\
\hline
\end{tabular}

It is very likely that the reduced steric bulk of Ap+ and Ap- does not lead selectively to mono Ap dialkyl complexes under the conditions used to generate the cations for polymerization studies. This hypothesis is supported by the observation that salt metathesis reactions with $[\mathrm{Ap}+\mathrm{K}]$ gave rise to complexes of the type $\left[\mathrm{Ap}+{ }_{2} \operatorname{Ln}(\mathrm{thf}) \mathrm{Cl}\right] .^{6}$

Temperature dependence studies of the organoyttrium catalyzed ethylene polymerization using the Ap* ligand revealed that the molecular weight increases with the reaction temperature. Furthermore, unusual small polydispersities down to $1.3(\mathrm{Mw} / \mathrm{Mn})$ were observed. It was concluded that a CCTP scenario between $\mathrm{Y}$ and TIBAO (triisobutylalumoxane) could be an explanation. ${ }^{42} \mathrm{~A}$ variety of experiments support this hypothesis. First, an increase of the Al to Y ration goes along with the formation of shorter polymer chains and all polymers contain an isopropyl endgroup steaming from TIBAO. 


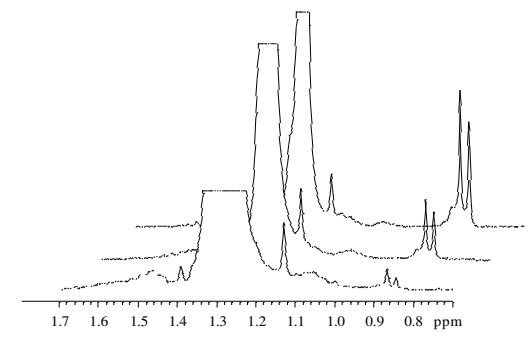

$\mathrm{Al} / \mathrm{Y}=100$
$\mathrm{Al} / \mathrm{Y}=50$

Figure 4. ${ }^{1} \mathrm{H}$ NMR spectra $\left(\mathrm{C}_{2} \mathrm{D}_{2} \mathrm{Cl}_{4}, 120^{\circ} \mathrm{C}\right)$ of PE. The inset shows the signal of the methyl groups of the isopropyl endgroup.

Secondly, a time depending growth of the polymer chain was observed. Polymer samples taken from one run $\left(80{ }^{\circ} \mathrm{C}\right.$ and 5 bar) were indicative of a increase of the molecular weight with the polymerization time (Figure 5).

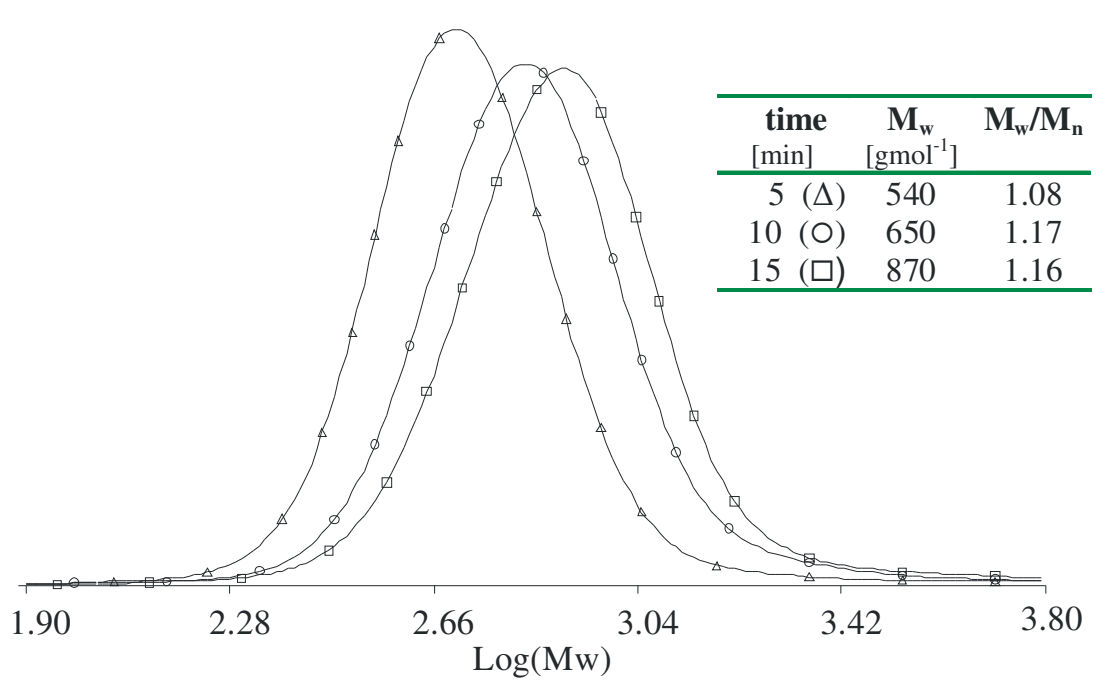

Figure 5. Time depended increase of the molecular weight of the polymers as determined by SEC.

Thirdly, if chain transfer is fast in relation to chain growing very narrowly distributed polymers should be observed. Optimization of the reaction conditions in this regard led to the synthesis of PE with a polydispersity $\mathrm{Mw} / \mathrm{Mn}<1.1$ up to a molecular weight of $4000 \mathrm{~g} / \mathrm{mol}$ (Table 5). 
Table 5. Optimization of the reaction conditions towards low polydispersity using the Ap*Y based catalyst system.

$\begin{array}{ccccc}\begin{array}{c}\mathbf{A l} / \mathbf{Y} \\ {[\mathrm{mol} / \mathrm{mol}]}\end{array} & \begin{array}{c}\mathbf{m}_{\mathbf{p o l} .} \\ {[\mathrm{g}]}\end{array} & \begin{array}{c}\text { activity } \\ {\left[\mathrm{kg}_{\mathrm{PE}} \mathrm{mol}_{\mathrm{cat}}{ }^{-1} \mathrm{~h}^{-1} \mathrm{bar}^{-1}\right]}\end{array} & \begin{array}{c}\mathbf{M}_{\mathbf{w}} \\ {\left[\mathrm{gmol}^{-1}\right]}\end{array} & \mathbf{M}_{\mathbf{w}} / \mathbf{M}_{\mathbf{n}} \\ 0 & 0 & 0 & \text { n.d. } & \text { n.d. } \\ 50 & 4.7 & 376 & 3940 & 1.09 \\ 100 & 2.1 & 168 & 1460 & 1.05 \\ 20^{\mathrm{a}} & 10.1 & 808 & 15600 & 1.4 \\ \text { Ammonium borate: } & {\left[\mathrm{R}_{2} \mathrm{~N}\left(\mathrm{CH}_{3}\right) \mathrm{H}\right]^{+}\left[\mathrm{B}\left(\mathrm{C}_{6} \mathrm{~F}_{5}\right)_{4}\right]^{-}\left(\mathrm{R}=\mathrm{C}_{16} \mathrm{H}_{31}-\mathrm{C}_{18} \mathrm{H}_{35}\right), \mathrm{Y} / \mathrm{B}=1 / 1.1 \text {. Aluminum alkyl: }} & \text { TIBAO. } \\ \text { Pressure: } 5 \text { bar. Temperature: } 80^{\circ} \mathrm{C} \text {. Time } 15: \text { min. }{ }^{\mathrm{T}} \text { Temperature } 100{ }^{\circ} \mathrm{C} .\end{array}$

Higher molecular weights can not be obtained with a polydispersity of around 1.1 because polymers start to precipitate during polymerization and chain transfer is disturbed. Temporarily a bimodal distribution is observed (polymer in solution and polymer that is precipitated). After all polymer is precipitated a monomodal distribution is observed again which is slightly broader but sill indicative of a controlled process (last run Table 5).

Since synthesis of the trisalkyl precursors (from which the Ap dialkyls and the organo cations that undergo CCTP are generated) is challenging, especially for the early lanthanoids, better accessible precursors were searched for. A series of aminopyridinate stabilized rare earth amide complexes were synthesized and characterized. The bulky aminopyridines Ap*-H and $\mathrm{Ap}^{-}-\mathrm{H}$ were introduced via amine elimination reaction with $\left[\mathrm{Ln}(\operatorname{thf})_{2}\left\{\mathrm{~N}\left(\mathrm{SiHMe}_{2}\right)_{2}\right\}_{3}\right](\mathrm{Ln}=\mathrm{Y}$, La) to obtain the corresponding mono aminopyridinates. Unfortunately, these complexes are not able to undergo CCTP with ethylene in the presence of aluminum alkyls as the corresponding dialkyl complexes do. Investigations of the reactions of the rare earth aminopyridinate complexes with triethylaluminum or diisobutylaluminumhydride reveal a fast transfer of the aminopyridinato ligand to aluminum. The products of this transfer reaction are aminopyridinate stabilized aluminum dialkyls. ${ }^{43}$

\section{Variation of the Aluminum Alkyl and of the Supporting Ligand and Synthesis of Functionalized PE}

High control in ethylene polymerization was observed for the Ap*Y catalyst system in combination with TIBAO. ${ }^{42}$ The question arose: are other alumoxanes or aluminum alkyls able to promote CCTP as well? 
Table 6. CCTP with the Ap* Y organo cation catalyst - influence of the aluminum alkyl.

$\begin{array}{cccccc}\text { Al-alkyl } & \begin{array}{c}\mathbf{A l} / \mathbf{Y} \\ {[\mathrm{mol} / \mathrm{mol}]}\end{array} & \begin{array}{c}\mathbf{m}_{\mathbf{p o l} .} \\ {[\mathrm{g}]}\end{array} & \begin{array}{c}\text { activity } \\ {\left[\mathrm{kg}_{\mathrm{PE}} \mathrm{mol}_{\mathrm{Kat}}{ }^{-1} \mathrm{~h}^{-1} \mathrm{bar}^{-1}\right]}\end{array} & \begin{array}{c}\mathbf{M}_{\mathbf{w}} \\ {\left[\mathrm{gmol}^{-1}\right]}\end{array} & \mathbf{M}_{\mathbf{w}} / \mathbf{M}_{\mathbf{n}} \\ \text { TOA } & 100 & 0.5 & 40 & \text { n.d. } & \text { n.d. } \\ \text { TIBA } & 100 & 0.9 & 80 & \text { n.d. } & \text { n.d. } \\ \text { TIBA }^{\mathrm{a}} & 100 & 4.3 & 129 & 2660 & 1.2 \\ \text { TOAO }^{2} & 100 & 1.9 & 152 & 2580 & 1.1 \\ \text { TIBAO } & 100 & 2.1 & 168 & 1460 & 1.05 \\ \text { TPPAO } & 50 & 1.9 & 152 & 2770 & 1.2\end{array}$

Ap*Y(thf) $\left.\left.\mathrm{CH}^{2} \mathrm{SiMe}_{3}\right)_{2}\right]: 10 \mu \mathrm{mol}$, ammonium borate: $\left[\mathrm{R}_{2} \mathrm{~N}\left(\mathrm{CH}_{3}\right) \mathrm{H}\right]^{+}\left[\mathrm{B}\left(\mathrm{C}_{6} \mathrm{~F}_{5}\right)_{4}\right]^{-}\left(\mathrm{R}=\mathrm{C}_{16} \mathrm{H}_{31}-\mathrm{C}_{18} \mathrm{H}_{35}\right), \mathrm{Y} / \mathrm{B}=$ 1/1.1, pressure: 5 bar, time: 15 min. ${ }^{\mathrm{a}} 100^{\circ} \mathrm{C}, 10 \mathrm{bar}, 20 \mathrm{~min}$.

As shown in Table 6 the organoyttrium cation catalyzed chain growing on aluminum is not limited to TIBAO themselves, but can be carried out with a variety of aluminum alkyls. However, the use of partially hydrolyzed Al-alkyls seems to have a strong beneficial effect on the ethylene polymerization activity. This behaviour could be explained by a stronger coordination of the aluminum trialkyls at the organoyttrium cation compared to the less electron rich alumoxanes. Consequently, the equilibrium between the CGS and the CTS is shifted towards the CTS. This goes along with a lower concentration of CGS and with a lower overall productivity. For the synthesis of well defined Al-terminated PE the use of simple aluminum alkyls is of advantage since they are better defined and the hydrolysis step can be waived. As shown in Scheme 1 a variety of ligands are related to Ap ligands and may also undergo CCTP. A sterically demanding amidine and guanidine, $\mathrm{Am}^{*}-\mathrm{H}$ and $\mathrm{Gu}^{*}-\mathrm{H}$, respectively (Scheme 16), were investigated in this regard. ${ }^{44}$

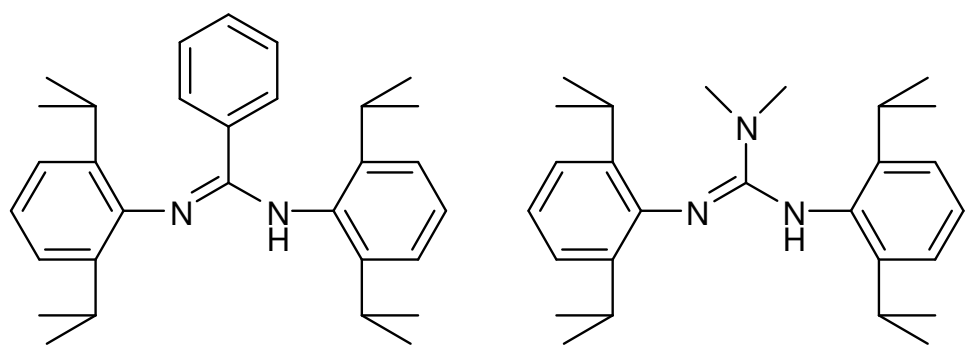

Scheme 16. Structure of Am*-H (right) and $\mathrm{Gu}^{*}$-H (left).

Selected polymerization results are shown in Table 7. They are indicative of CCTP in all cases. The Am* based catalyst system is the most productive one in the presence of Al alkyls 
like triisobutylaluminum (= TIBA). This catalyst system is also very productive in combination with other aluminum alkyls like triethylaluminum.

Table 7. Ethylene polymerization a comparison of a $\mathrm{Y}$ aminopyridinate, a amidinate and a guanidinate.

\begin{tabular}{|c|c|c|c|c|}
\hline precatalyst & $\begin{array}{l}\mathrm{m}_{\text {Pol. }} \\
{[\mathrm{g}]}\end{array}$ & $\begin{array}{c}\text { activity } \\
{\left[\mathrm{kg}_{\mathrm{PE}} \mathrm{mol}_{\mathrm{Kat}}{ }^{-1} \mathrm{~h}^{-1} \mathrm{bar}^{-1}\right]}\end{array}$ & $\begin{array}{c}\mathrm{M}_{\mathrm{w}} \\
{[\mathrm{g} / \mathrm{mol}]}\end{array}$ & $\mathrm{M}_{\mathrm{w}} / \mathrm{M}_{\mathrm{n}}$ \\
\hline$\left[\mathrm{Ap}^{*} \mathrm{Y}(\mathrm{thf}) \mathrm{R}\right]^{\mathrm{b}}$ & 0.9 & 80 & 1200 & 1.3 \\
\hline$[\mathrm{Am} * \mathrm{Y}(\mathrm{thf}) \mathrm{R}]^{\mathrm{b}}$ & 12.0 & 960 & 4200 & 1.2 \\
\hline$[\mathrm{Am} * \mathrm{Y}(\mathrm{thf}) \mathrm{R}]^{\mathrm{c}}$ & 6.5 & 520 & 1550 & 1.1 \\
\hline$\left[\mathrm{Gu}^{*} \mathrm{Y}(\mathrm{thf}) \mathrm{R}\right]^{\mathrm{b}}$ & 3.0 & 240 & 2160 & 1.1 \\
\hline$\left[\mathrm{Gu}^{*} \mathrm{Y}(\mathrm{thf}) \mathrm{R}\right]^{\mathrm{c}}$ & 1.2 & 96 & 1460 & 1.07 \\
\hline
\end{tabular}

Al terminated PE can undergo an oxidation reaction with $\mathrm{O}_{2}$ which leads to alkoxides that can be hydrolysed to form alcohols. ${ }^{45}$ These alcohols can be converted into a variety of functionalized PE materials as shown in Scheme $17 .^{44,46}$
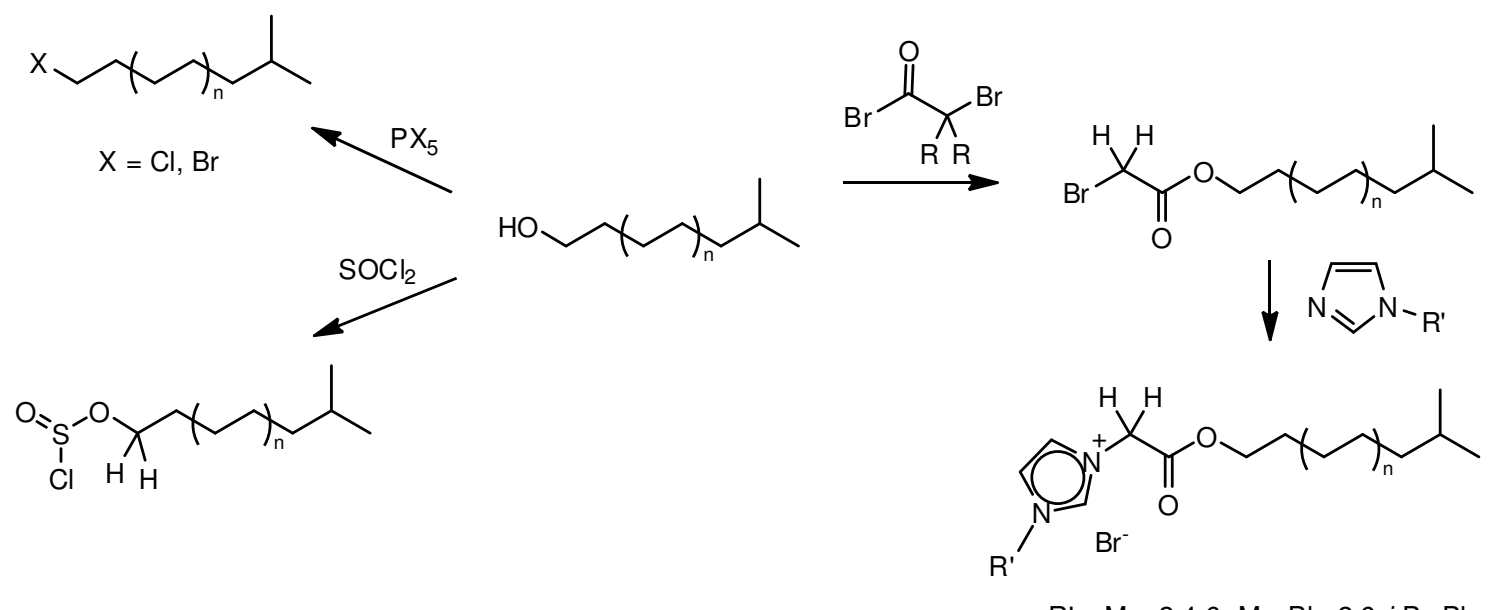

Scheme 17. Modifications of OH-terminated PE.

The N-heterocyclic carbene precursor (Scheme 17, right bottom) is soluble only at temperatures above $90{ }^{\circ} \mathrm{C}$ and could be the basis of a recyclable ligand or catalyst complex. 
Cooling down to room temperature should allow precipitating the ligand/catalyst and reusing them.

\section{Isoprene Polymerization Mediated by Rare Earth Aminopyridinates}

Isoprene polymerization catalyzed by organolanthanoid cations has gained a lot of attention after the initial reports were published by two groups simultaneously. ${ }^{47}$ Rare earth complexes of the type $\left[(\mathrm{L}) \mathrm{LnR}_{2}(\mathrm{D})\right]\left(\mathrm{R}=\mathrm{CH}_{2} \mathrm{SiMe}_{3}, \mathrm{AlMe}_{4}, o-\mathrm{CH}_{2} \mathrm{C}_{6} \mathrm{H}_{4} \mathrm{NMe}_{2}, \mu^{3}-\mathrm{C}_{3} \mathrm{H}_{5}, \mathrm{D}=\right.$ thf) where $\mathrm{L}$ is a cyclopentadienyl ${ }^{48}$ or an anionic N-ligand, ${ }^{49,50}$ are known to mediate isoprene polymerization. $^{51}\left[\left\{\mathrm{Me}_{2} \mathrm{Si}\left(\mathrm{C}_{5} \mathrm{Me}_{4}\right)-(\mathrm{PHCy})\right\} \mathrm{YCH}_{2} \mathrm{SiMe}_{3}\right]_{2} \quad\left(\mathrm{Cy}=\right.$ cyclohexyl $^{47 \mathrm{~b}}$ or

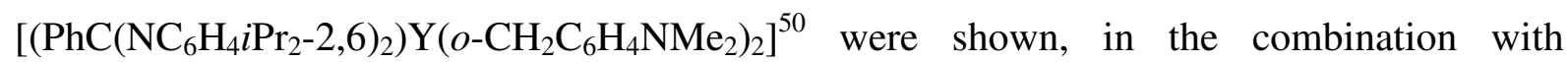
$\left[\mathrm{Ph}_{3} \mathrm{C}\right]\left[\mathrm{B}\left(\mathrm{C}_{6} \mathrm{~F}_{5}\right)_{4}\right]$, to polymerize with very high regio- and stereoselectivities (3,4-selectivity: $>99 \%$, mmmm $>99 \%$ ). In addition, it was observed, that the amidinate complex switches the stereoselectivity drastically from 3,4-isospecific to cis-1,4-selective by addition of $\mathrm{AlMe}_{3}$. Furthermore, half-sandwich complexes of the type $\left[\left(\mathrm{C}_{5} \mathrm{Me}_{5}\right) \operatorname{Ln}\left(\mathrm{AlMe}_{4}\right)_{2}\right](\mathrm{Ln}=\mathrm{Y}, \mathrm{La}, \mathrm{Nd})$, are (after activation) highly active catalysts for the living trans-1,4-selective (up to 99.5\%) polymerization of isoprene. ${ }^{48 \mathrm{~b}}$ Although 3,4-polyisoprene is used as an important component of high-performance rubber for example in tires, ${ }^{52}$ the number of 3,4 -selective catalyst systems is smaller in contrast to systems which yield high cis-1,4-polyisoprene (natural rubber). ${ }^{48 \mathrm{~d}, 49 \mathrm{e}, 50,53,54}$

In analogy to the synthesis of organoyttrium cations (Scheme 14) proceeds the synthesis of organoscandium cations. Ap ligand stabilized dialkyls are accessible in high yield from alkyl and benzyl precursors (Scheme 18).
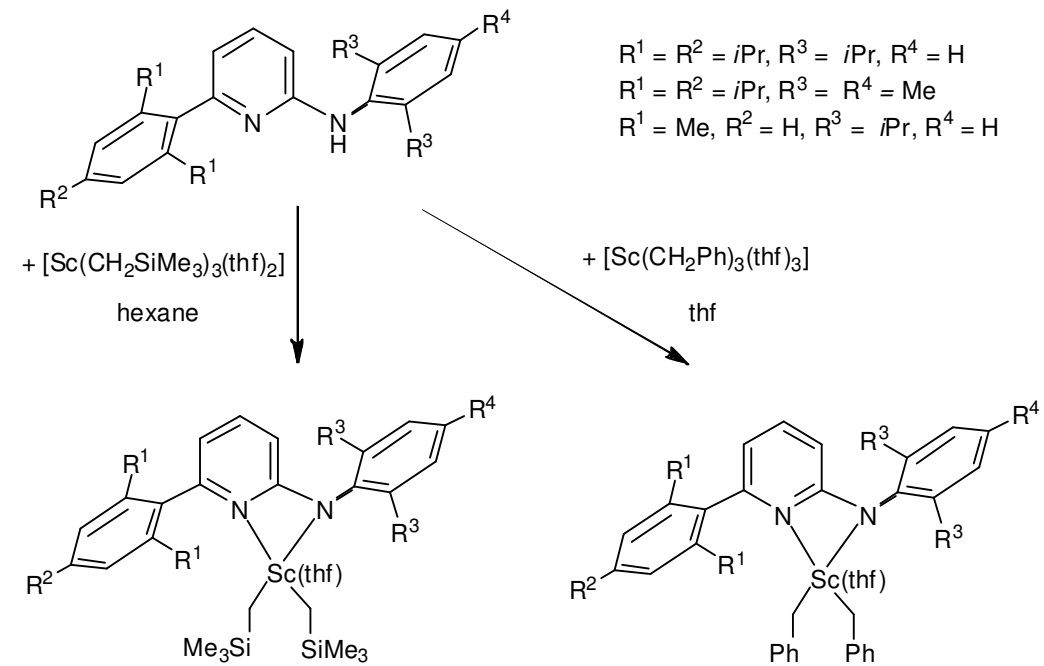

Scheme 18. Synthesis of scandium aminopyridinates. 
The dialkyl and dibenzyl complexes shown in Scheme 18 can be activated with borates like $\left[\mathrm{Ph}_{3} \mathrm{C}\right]\left[\mathrm{B}\left(\mathrm{C}_{6} \mathrm{~F}_{5}\right)_{4}\right]$ and $\left[\mathrm{C}_{6} \mathrm{H}_{5} \mathrm{NHMe}_{2}\right]\left[\mathrm{B}\left(\mathrm{C}_{6} \mathrm{H}_{5}\right)_{4}\right]$ to form organo cations (Scheme 19).

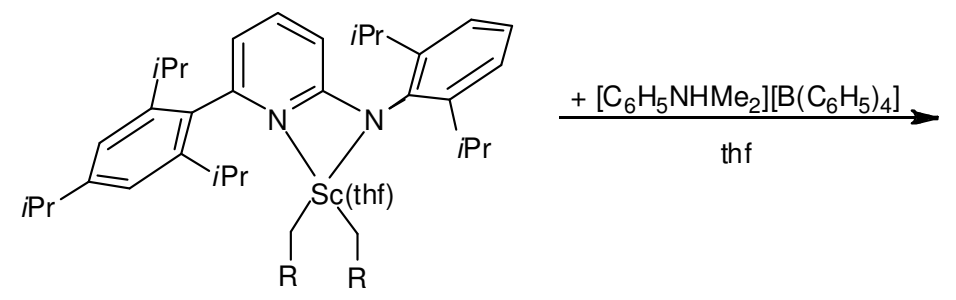

Scheme 19. Synthesis of organo scandium cations.

Scandium cations generated by addition of $\left[\mathrm{Ph}_{3} \mathrm{C}\right]\left[\mathrm{B}\left(\mathrm{C}_{6} \mathrm{~F}_{5}\right)_{4}\right]$ are active and selective catalysts for the controlled 3,4-selective polymerization of isoprene. The presence of alkylaluminum compounds leads to drastical changes in the microstructure of the polymers. The highest stereo- and regioselectivity was observed for the catalyst/activator system [Ap* $\left.\mathrm{Sc}(\mathrm{thf}) \mathrm{Bn}_{2}\right] /$ $\left[\mathrm{Ph}_{3} \mathrm{C}\right]\left[\mathrm{B}\left(\mathrm{C}_{6} \mathrm{~F}_{5}\right)_{4}\right]\left(3,4-\right.$ content $95 \%, \mathrm{~mm}=100 \%, \mathrm{mmmm}=35 \%, M_{\mathrm{w}} / M_{\mathrm{n}}=1.68, \mathrm{Bn}=$ benzyl), whereas the system $\left[\mathrm{Ap} * \mathrm{Sc}(\mathrm{thf})\left(\mathrm{CH}_{2} \mathrm{SiMe}_{3}\right)_{2}\right] /\left[\mathrm{C}_{6} \mathrm{H}_{5} \mathrm{NH}\left(\mathrm{CH}_{3}\right)_{2}\right]\left[\mathrm{B}\left(\mathrm{C}_{6} \mathrm{~F}_{5}\right)_{4}\right]$ shows the narrowest molecular weight distribution $\left(3,4\right.$-content $\left.93 \%, M_{\mathrm{w}} / M_{\mathrm{n}}=1.26\right)$. The ternary systems $\quad\left[\mathrm{Ap} * \mathrm{Sc}(\mathrm{thf})\left(\mathrm{N}\left\{\mathrm{SiHMe}_{2}\right\}_{2}\right] / \mathrm{AlR}_{3} /\left[\mathrm{C}_{6} \mathrm{H}_{5} \mathrm{NH}\left(\mathrm{CH}_{3}\right)_{2}\right]\left[\mathrm{B}\left(\mathrm{C}_{6} \mathrm{~F}_{5}\right)_{4}\right] \quad\right.$ and $\left[\mathrm{Sc}\left\{\mathrm{N}\left(\mathrm{SiHMe}_{2}\right)_{2}\right\}_{3}(\mathrm{thf})\right] / \mathrm{AlR}_{3} /\left[\mathrm{C}_{6} \mathrm{H}_{5} \mathrm{NH}\left(\mathrm{CH}_{3}\right)_{2}\right]\left[\mathrm{B}\left(\mathrm{C}_{6} \mathrm{~F}_{5}\right)_{4}\right](\mathrm{R}=\mathrm{Me}, i \mathrm{Bu})$ polymerize isoprene cis-1,4-selective. The use of binary catalyst systems based on larger rare earth metals leads to a degrease of the 3,4 content and an increase of an cis-1,4 content. ${ }^{55}$

\section{Conclusions}

Rare earth atoms stabilized by bulky aminopyridinato ligands are a versatile class of polymerization catalysts. The tailoring of the steric bulk of the Ap ligand in combination with the choice of 17 similar (in terms of the general reactivity) but distinct differently (in terms of the ionic radii) rare earth atoms allows a fine tuning of the catalyst activity and selectivity. Some preliminary proof of principle studies have been carried out. The potential of this (polymerization) catalyst class is large but largely unexplored. 


\section{Acknowledgement}

We thank the DFG for financial support within the SPP 1166 "Lanthanoid-specific functionalities in molecules and materials". I also like to thank all the talented coworkers that have worked in these projects for their inspiring input.

${ }^{1}$ For review articles on aminopyridinato ligands see: a) R. Kempe, H. Noss, T. Irrgang, $J$. Organomet. Chem. 2002, 647, 12-20; b) R. Kempe, Eur. J. Inorg. Chem. 2003, 791-803.

${ }^{2}$ For discussion of the binding modes see: S. Deeken, G. Motz, R. Kempe, Z. Anorg. Allg. Chem. 2007, 633, 320-325.

${ }^{3}$ For the general applicability of the ligands see: G. Glatz, S. Demeshko, G. Motz, R. Kempe, Eur. J. Inorg. Chem. 2009, 1385-1392.

${ }^{4}$ The term rare earth (metal or atom) includes the group 3 elements Sc, Y und La as well as the lanthanoids themselves the elements from Ce till $\mathrm{Lu}$.

${ }^{5}$ N. M. Scott, T. Schareina, O. Tok, R. Kempe, Eur. J. Inorg. Chem. 2004, 3297-3304.

${ }^{6}$ N. M. Scott, R. Kempe, Eur. J. Inorg. Chem. 2005, 1319-1324.

${ }^{7}$ W. P. Kretschmer, A. Meetsma, B. Hessen, N. M. Scott, S. Qayyum, R. Kempe, Z. Anorg. Allg. Chem. 2006, 632, 1936-1938.

${ }^{8}$ For selected reviews please see: a) A. E. Shilov, G. B. Shul'pin, Chem. Rev. 1997, 97, 28792932. b) C. Jia, T. Kitamura, Y. Fujiwara, Acc. Chem. Res. 2001, 34, 633-639. c) K. Godula, D. Sames, Science 2006, 312, 67-72; d) F. Kakiuchi, T. Kochi, Synthesis 2008, 19, 30133039.

9 a) M. Brookhart, M. L. H. Green, J. Organomet. Chem. 1983, 250, 395- 408; b) W. J. Evans, L. A. Hughes, T. P. Hanusa, J. Am. Chem. Soc. 1984, 106, 4270-4272; c) W. J. Evans, L. A. Hughes, T. P. Hanusa, Organometallics 1986, 5, 1285-1291; d) P. B .Hitchcock, J. A. K. Howard, M. F. Lappert, S. Prashar, J. Organomet. Chem. 1992, 437, 177-189; e) S. Qayyum, K. Haberland, C. M. Forsyth, P. C. Junk, G. B. Deacon, R. Kempe, Eur. J. Inorg. Chem. 2008, 557-562.

${ }^{10}$ a) P. L. Watson, J. Chem. Soc., Chem. Commun. 1983, 276-277; b) P. L.Watson, G. B. Parshall, Acc. Chem. Res. 1985, 18, 51-56; c) P. L. Watson, J. Am. Chem. Soc. 1983, 105, 6491-6493; d) N. Barros, O. Eisenstein, L. Maron, Dalton Trans. 2006, 3052-3057.

11 a) K. H. den Haan, J. H. Teuben, J. Chem. Soc., Chem. Commun. 1986, 682-683; b) M. E. Thompson, S. M. Baxter, A. R. Bulls, B. J. Burger, M. C. Nolan, B. D. Santarsiero, W. P. Schaefer, J. E. Bercaw, J. Am. Chem. Soc. 1987, 109, 203-219; c) K. H. den Haan, Y. Wiestra, J. H. Teuben, Organometallics 1987, 6, 2053-2060; d) W. J. Evans, T. A. Ulibarri, J. 
W. Ziller, Organometallics 1991, 10, 134-142; e) M. Booij, A. Meetsma, J. H. Teuben, Organometallics 1991, 10, 3246-3552; f) M. Booij, B. J. Deelman, R. D. Duchateau, J. Postma, A. Meetsma, J. H. Teuben, Organometallics 1993, 12, 3531-3540; g) W. J. Evans, J. M. Perotti, J. W. Ziller, Inorg. Chem. 2005, 44, 5820-5825; h) W. J. Evans, J. M. Perotti, J. W. Ziller, J. Am. Chem. Soc. 2005, 127, 3894-3909; i) W. J. Evans, T. M. Champagne, J. W. Ziller, J. Am. Chem. Soc. 2006, 128, 14270-14271.

12 For selected examples please see: a) M. D. Fryzuk, T. S. Haddad, S. J. Rettig, Organometallics 1991, 10, 2026-2036; b) Y. Mu, W. E Piers, D. C. Mac Quarrie, M. J. Zaworotko, V. G. Young, Organometallics 1996, 15, 2720-2726; c) R. Duchateau, T. Tuinstra, E. A. C. Brussee, A. Meetsma, P. T. van Duijnen, J. H. Teuben, Organometallics 1997, 16, 3511-3522; d) D. J. H. Emslie, W. E. Piers, M. Parvez, R. McDonald, Organometallics 2002, 21, 4226-4240; e) D. J. H. Emslie, W. E. Piers, M. Parvez, Dalton Trans. 2003, 2615-2620; f) L. K. Knight, W. E. Piers, P. Fleurat-Lessard, P. Masood, R. McDonald, Organometallics 2004, 23, 2087-2094; g) L. K. Knight, W. E. Piers, R. McDonald, Organometallics, 2006, 25, 3289-3292; h) M. Zimmermann, F. Estler, E. Herdtweck, W. K. Törnroos, R. Anwander, Organometallics 2007, 26, 6029-6041.

13 G. G. Skvortsov, G. K. Fukin, A. A. Trifonov, A. Noor, C. Döring, R. Kempe, Organometallics 2007, 26, 5770-5773.

${ }^{14}$ S. Qayyum, G. G. Skvortsov, G. K. Fukin, A. A. Trifonov, W. P. Kretschmer, C. Döring, R. Kempe, Eur. J. Inorg. Chem. 2010, 248-257.

${ }^{15}$ D. M. Lyubov, C. Döring, G. K. Fukin, A. V. Cherkasov, A. V. Shavyrin, R. Kempe, A. A. Trifonov, Organometallics 2008, 27, 2905-2907.

${ }^{16}$ W. P. Kretschmer, A. Meetsma, B. Hessen, T. Schmalz, S. Qayyum, R. Kempe, Chem. Eur. J. 2006, 12, 8969-8978.

${ }^{17}$ Selected reviews on rare earth metal hydride complexes: a) M. Masayoshi, Z. Hou, Nature Chem. 2010, 2, 257-268; b) M. Konkol, J. Okuda, Coord. Chem. Rev. 2008, 252, 1577-1591; c) A. A. Trifonov, Rus. Chem. Rev. 2007, 76, 1051-1072; d) Z. Hou, M. Nishiura, T. Shima, Eur. J. Inorg. Chem. 2007, 2535-2545; e) Z. Hou, Bull. Chem. Soc. Jpn. 2003, 76, 22532266; f) J. Okuda, Dalton Trans. 2003, 2367-2378; g) S. Arndt, J. Okuda, Chem. Rev. 2002, 102, 1953-1976; h) G. A. Molander, J. A. C. Romero, Chem. Rev. 2002, 102, 2161-2186; i) Z. Hou, Y. Wakatsuki, Coord. Chem. Rev. 2002, 231, 1-22; j) Z. Hou, Y. Wakatsuki, in Science of Synthesis (Eds.: T. Imamoto, R. Noyori), Thieme, Stuttgart, 2002, vol. 2, p. 849942; k) A. J. Hoskin, D. W. Stephan, Coord. Chem. Rev. 2002, 233-234, 107-129; 1) M. 
Ephritikhine, Chem. Rev. 1997, 97, 2193-2242; m) H. Schumann, J. A. Meese-Marktscheffel, L. Esser, Chem. Rev. 1995, 95, 865-986; n) F. T. Edelmann, in Comprehensive Organometallic Chemistry II (Eds.: E. W. Abel, F. G. A. Stone, G. Wilkinson, M. F. Lappert), Pergamon, Oxford, 1995, vol. 4, p. 11-212; o) C. J. Schaverien, Adv. Organomet. Chem. 1994, 36, 283-362.

18 a) W. J. Evans, J. H. Meadows, A. L. Wayda, J. Am. Chem. Soc. 1982, 104, 2015- 2017; b) W. J. Evans, J. H. Meadows, T. P. Hanusa, J. Am. Chem. Soc. 1984, 106, 4454-4460. c) W. J. Evans, M. S. Sollberger, S. I. Khan, R. Bau, J. Am. Chem. Soc. 1988, 110, 439-446.

19 a) Dissertation K. C. Hultzsch Johannes Gutenberg-Universität Mainz 1999; b) K. C. Hultzsch, T. P. Spaniol, J. Okuda, Angew. Chemie 1999, 111, 163-165; Angew. Chem. Int. Ed. 1999, 38, 227-230.

${ }^{20}$ Z. Hou, Y. Zhang,; O. Tardif, Y. Wakatsuki, J. Am. Chem. Soc. 2001, 123, 9216-9217.

${ }^{21}$ M. Yousufuddin, M. J. Gutmann, J. Baldamus, O. Tardif, Z. Hou, S. A. Mason, G. J. McIntyre, R. Bau, J. Am. Chem. Soc. 2008, 130, 3888-3891.

${ }^{22}$ S. Qayyum, A. Noor, G. Glatz, R. Kempe, Z. Anorg. Allg. Chem. 2009, 635, 2455-2458.

${ }^{23}$ For reviews see: a) G. B. Deacon, C. M. Forsyth, in Inorganic Chemistry Highlights, ed. G. Meyer, D. Naumann and L. Wesemann, Wiley - VCH, Weinheim, 2002, ch 7, p139-153; b) K. Müller-Buschbaum, Z. Anorg. Allg. Chem. 2005, 631, 811-828.

${ }^{24}$ For selected examples published prior to our article see: a) G. B. Deacon, C. M. Forsyth, P. C. Junk, B. W. Skelton, A. H. White, Chem. Eur. J. 1999, 5, 1452-1459; b) G. B. Deacon, T. Feng, C. M. Forsyth, A. Gitlits, D. C. R. Hockless, Q. Shen, B. W. Skelton, A. H. White, J. Chem. Soc., Dalton Trans. 2000, 961-966; c) G. B. Deacon, A. Gitlits, P. W. Roesky, M. K. Burgstein, K.C. Lim, B.W. Skelton, A.H. White, Chem. Eur. J. 2001, 7, 127-128; d) G.B. Deacon, C.M. Forsyth, A. Gitlits, R. Harika, P.C. Junk, B.W. Skelton, A.H. White, Angew. Chem. 2002, 114, 1383-1385; Angew. Chem., Int. Ed. Engl. 2002, 41, 3249-3251; e) K. Müller-Buschbaum, Z. Anorg. Allg. Chem. 2003, 629, 2127-2132; f) G.B. Deacon, C.M. Forsyth, A. Gitlits, B.W. Skelton, A.H. White, Dalton Trans. 2004, 1239-1247; g) K. MüllerBuschbaum, C. Quitmann, Inorg. Chem. 2006, 45, 2678-2687; h) G.B. Deacon, C.M. Forsyth, P.C. Junk, S.G. Leary, New. J. Chem. 2006, 30, 592-596; i) C.C. Quitmann, V. Bezugly, F.R. Wagner, K. Müller-Buschbaum, Z. Anorg. Allg. Chem. 2006, 632, 1173-1186;

${ }^{25}$ For examples see: a) J. Hitzbleck, A.T. O’Brien, C.M. Forsyth, G.B. Deacon, K. RuhlandtSenge, Chem. Eur. J. 2004, 10, 3315-3323; b) J. Hitzbleck, G.B. Deacon, K. Ruhlandt-Senge, Angew. Chem. 2004, 116, 5330-5332; Angew. Chem., Int. Ed. Engl. 2004, 43, 5218-5230. 
${ }^{26}$ S. Qayyum, K. Haberland, C. M. Forsyth, P. C. Junk, G. B. Deacon, R. Kempe, Eur. J. Inorg. Chem. 2008, 557-562.

27 a) K. M. Stridsberg, M. Ryner, A.-C. Albertsson, Adv. Polym. Sci. 2002, 157, 42-65; b) A. C. Albertsson, I. K. Varma, Adv. Polym. Sci. 2002, 157, 2-41.

${ }^{28}$ a) Z. Hou, Y. Wakatsuki, Coord. Chem. Rev. 2002, 231, 1-22; b) S. Agarwal, C. Mast, K. Dehnicke, A. Greiner, Macromol. Rapid Commun. 2000, 21, 195-212; c) H. Yasuda, J. Organometallic Chem. 2002, 647, 128-138.

${ }^{29}$ a) M. Okada, Prog. Polym. Sci. 2002, 27, 87-133; b) M. Vert; Biomacromolecules 2005, 6, 538-546; c) A.-C. Albertsson, I. K. Varma, Biomacromolecules 2003, 4, 1466-1486; d) T. Freier, Adv. Polym. Sci. 2006, 203, 1-61; e) M. S. Lindblad, Y. Liu, A.-C. Albertsson, E. Ranucci, S. Karlsson, Adv. Polym. Sci. 2002, 157, 141-160; f) S. Matsumura, Adv. Polym. Sci. 2006, 194, 95-132.

30 a) S. M. Cendrowski-Guillaume, G. Le Gland, M. Nierlich, M. Ephritikhine, Organometallics 2000, 19, 5654-5660; b) S. M. Cendrowski-Guillaume, M. Nierlich, M. Lance, M. Ephritikhine, Organometallics 1998, 17, 786-788.

31 a) S. M. Guillaume, M. Schappacher, A. Soum, Macromolecules 2003, 36, 54-60; b) I. Palard, A. Soum, S. M. Guillaume, Chem. Eur. J. 2004, 10, 4054-4062; c) I. Palard, A. Soum, S. M. Guillaume, Macromolecules 2005, 6888-6894; d) I. Palard, M. Schappacher, A. Soum, S. M. Guillaume, Polym. Int. 2006, 55, 1132-1137.

${ }^{32}$ H. Noss, M. Oberthür, C. Fischer, W. P. Kretschmer, R. Kempe, Eur. J. Inorg. Chem. 1999, 2283-2288.

${ }^{33}$ S. M. Guillaume, M. Schappacher, N. M. Scott, R. Kempe, J. Polym. Sci. Part A: Polym. Chem. 2007, 45, 3611-3619.

${ }^{34}$ a) Y. Shen, Z. Shen, Y. Zhang, Q. Hang, J. Polym. Sci., Part A : Polym. Chem. 1997, 35, 1339-1352; b) Y. Shen, Y.; K. J. Zu, Z. Shen, K. Yao, J. Polym. Sci., Part A : Polym. Chem. 1996, 34, 1799-1805; c) Y. Shen, Z. Shen, J. Shen, Y. Zhang, K. Yao, Macromolecules 1996, 29, 3441-3446.

35 a) S. Agarwal, M. Karl, K. Dehnicke, G. Seybert, W. Massa, A. Greiner, J. Appl. Polym. Sci. 1999, 73, 1669-1674; b) S. Agarwal, C. Mast, S. Anfang, M. Karl, K. Dehnicke, A. Greiner, Polym. Prepr. 1998, 39, 414-415; c) S. Agarwal, M. Karl, S. Anfang, K. Dehnicke, A. Greiner, Polym. Prepr. 1998, 39, 361-362; d) S. Agarwal, A. Greiner, J. Chem. Soc., Perkin Trans. 2002, 2033-2042. 
${ }^{36}$ T. J. Woodman, M. Schormann, D. L. Hughes, M. Bochmann, Organometallics 2004, 23, 2972-2979.

${ }^{37}$ R. Kempe, Chem. Eur. J. 2007, 13, 2764-2773.

38 a) E. G. Samsel, Ethyl Corporation, EP 0539876, 1993; b) E. G. Samsel, Ethyl Corporation, EP 0574854, 1993.

39 a) J.-F. Pelletier, A. Mortreux, X. Olonde, K. Bujadoux, Angew. Chem. 1996, 108, 19801982; Angew. Chem. Int. Ed. 1996, 35, 1854-1856; b) J. F. Pelletier, K. Bujadoux, X. Olonde, E. Adisson, A. Mortreux, T. Chenal, US 5779942, 1998.

40 a) J. S. Rogers, G. C. Bazan, Chem. Commun. 2000, 1209-1210; b) G. C. Bazan, J. S. Rogers, C. C. Fang, Organometallics 2001, 20, 2059-2064; c) G. Mani, F. P. Gabbai, Angew. Chem. 2004, 116, 2313-2316; Angew. Chem. Int. Ed. 2004, 43, 2263-2266; d) G. Mani, F. P. Gabbai, J. Organomet. Chem. 2005, 690, 5145-5149; e) G. J. P. Britovsek, S. A. Cohen, V. C. Gibson, P. J. Maddox, M. van Meurs, Angew. Chem. 2002, 114, 507-509; Angew. Chem. Int. Ed. 2002, 41, 489-491; f) G. J. P. Britovsek, S. A. Cohen, V. C. Gibson, M. van Meurs, J. Am. Chem. Soc. 2004, 126, 10701-10712; g) M. van Meurs, G. J. P. Britovsek, V. C. Gibson, S. A. Cohen, J. Am. Chem. Soc. 2005, 127, 9913-9923; h) J. Saito, Y. Tohi, N. Matsukawa, M. Mitani and T. Fujita, Macromolecules, 2005, 38, 4955-4957. i) T. Chenal, X. Olonde, J.-F. Pelletier, K. Bujadoux, M. Mortreux, Polymer 2007, 48, 1844-1856; j) W. Zhang, L. R. Sita, J. Am. Chem. Soc. 2008, 130, 442-443; k) W. Zhang, J. Wei, L. R. Sita, Macromolecules 2008, 41, 7829-7833; 1) J. Wei, W. Zhang and L. R. Sita, Angew. Chem. 2010, 122, 1-4, Angew. Chem. Int. Ed., 2010, 49, 14-18.

${ }^{41}$ For selected reviews on cationic rare earth metal alkyls see: a) Z. Hou, Y. Luo, X. Li, J. Organomet. Chem. 2006, 691, 3114-3121; b) S. Arndt, J. Okuda, Adv. Synth. Catal. 2005, 347, 339-354; c) S. Arndt, J. Okuda, Chem. Rev. 2002, 102, 1953-1976; d) P. M. Zeimentz, S. Arndt, B. R. Elvidge, J. Okuda, Chem. Rev. 2006, 106, 2404-2433.

${ }^{42}$ W. P. Kretschmer, A. Meetsma, B. Hessen, T. Schmalz, S. Qayyum, R. Kempe, Chem. Eur. J. 2006, 12, 8969-8978.

${ }^{43}$ C. Doering, R. Kempe, Eur. J. Inorg. Chem. 2009, 412-418.

${ }^{44}$ W. P. Kretschmer, T. Bauer, B. Hessen, R. Kempe, Dalton Trans., 2010, 1 , accepted.

45 This process is run on tonne scale in chemical industry for short chain $\mathrm{Al}(\mathrm{PE})_{3}$.

${ }^{46}$ R. Briquel, J. Mazzolini, T. Le Bris, O. Boyron, F. Boisson, F. Delolme, F. D'Agosto, C. Boisson and R. Spitz, Angew. Chem. 2008, 120, 9451-9453; Angew. Chem. Int. Ed. 2008, 47, 9311-9313. 
47 a) S. Arndt, K. Beckerle, P. M. Zeimentz, T. P. Spaniol, J. Okuda, Angew. Chem. 2005, 117, 7640-7644; Angew. Chem. Int. Ed. 2005, 44, 7473-7477; b) L. Zhang, Y. Luo, Z. Hou, J. Am. Chem. Soc. 2005, 127, 14562-14563.

48 a) E. Le Roux, F. Nief, F. Jaroschik, K. W. Törnroos, R. Anwander, Dalton Trans. 2007, 4866. b) M. Zimmermann, K. W. Törnroos, R. Anwander, Angew. Chem. 2008, 120, 787-790; Angew. Chem. Int. Ed. 2008, 47, 775-778; c) M. Zimmermann, K. W. Törnroos, H. Sitzmann, R. Anwander, Chem. Eur. J. 2008, 14, 7266-7277; d) B. Wang, D. Cui, K. Lv, Macromolecules 2008, 41, 1983-1988; e) N. Yu, M. Nishiura, X. Li, Z. Xi, Z. Hou, Chem. Asian J. 2008, 3, 1406-1414; f) H. Zhang, Y. Luo, Z. Hou, Macromolecules 2008, 41, 10641066; g) A.-S. Rodriguesa, E. Kirillova, B. Vuilleminb, A. Razavic, J.-F. Carpentier, Polymer 2008, 49, 2039-2045.

49 a) L. Zhang, T. Suzuki, Y. Luo, M. Nishiura, Z. Hou, Angew. Chem. 2007, 119, 1941-1945; Angew. Chem. Int. Ed. 2007, 46, 1909-1913; b) Y. Luo, M. Nishiura, Z. Hou, J. Organomet. Chem. 2007, 692, 536-544; c) Y. Yang, B. Liu, K. Lv, W. Gao, D. Cui, X. Chen, X. Jing, Organometallics 2007, 26, 4575-4584; d) Y. Yang, Q. Wang, D. Cui, J. Polym. Sci. Part A: Polym. Chem. 2008, 46, 5251-5262; e) S. Li, W. Miao, T. Tang, W. Dong, X. Zhang, D. Cui, Organometallics 2008, 27, 718-725; f) W. Gao, D. Cui, J. Am. Chem. Soc. 2008, 130, 49844991.

${ }^{50}$ L. Zhang, M. Nishiura, M. Yuki, Y. Luo, Z. Hou, Angew. Chem. 2008, 120, 2682-2685; Angew. Chem. Int. Ed. 2008, 47, 2642-2645.

${ }^{51}$ For an example of a stoichiometric reaction of a yttrium alkyl complex with isoprene see: B. Liu, X. Liu, D. Cui, L. Liu, Organometallics 2009, 28, 1453-1460.

52 a) J. Wolpers, H. B. Fuchs, C. Herrmann, W. Hellermann, K. H. Nordsiek, Eur. Pat. Appl. EP 456902 A1, 1991; b) J. D. Massie, W. Hsu, A.F. Halasa, P. H. Sandstrom, US Pat. US 5356997, 1994; c) A. F. Halasa, W. Hsu, D. J. Zanzig, G. L. Allen, L. E. Austin, US Patent US 5627237 A, 1997.

${ }^{53}$ Selected reviews on isoprene polymerization: a) L. Porri, A. Giarrusso in Comprehensive Polymer Science, Vol. 4 (Eds.: G. C. Eastmond, A. Ledwith, S. Russo, P. Sigwalt), Pergamon, Oxford, 1989, pp. 74-79; b) R. Taube, G. Sylvester in Applied Homogeneous Catalysis with Organometallic Compounds, Vol. 2 (Eds.: B. Cornils, W. A. Herrmann), Wiley-VCH, Weinheim, 1996, pp. 285-315; c) L. Friebe, O. Nuyken, W. Obrecht, Adv. Polym. Sci. 2006, 204, 82-83; d) A. Fischbach, R. Anwander, Adv. Polym. Sci. 2006, 204, 155-191. 
${ }^{54}$ For examples of 3,4-polymerization of isoprene please see: a) G. Natta, L. Porri, A. Carbonaro, Makromol. Chem. 1964, 77, 126-138; b) W. Gronski, N. Murayama, H. J. Cantow, T. Miyamoto, Polymer 1976, 17, 358-360. c) G. Ricci, M. Battistella, L. Porri, Macromolecules 2001, 34, 5766-5769; d) C. Bazzini, A. Giarrusso, L. Porri, Macromol. Rapid Commun. 2002, 23, 922-927; e) Y. Nakayama, Y. Baba, H. Yasuda, K. Kawakita, N. Ueyama, Macromolecules 2003, 36, 7953-7958. f) C. Bazzini, A. Giarrusso, L. Porri, B. Pirozzi, R. Napolitano, Polymer 2004, 45, 2871-2875; g) Z. Hou, Y. Luo, X. Li, J. Organomet. Chem. 2006, 691, 3114-3121.

${ }^{55}$ C. Doering, W. P. Kretschmer, R. Kempe, Eur. J. Inorg. Chem. 2010, in press. 